\title{
EFEITO DO ESTRESSE HÍDRICO EM ALGUMAS RESPOSTAS MORFOLÓGICAS E FISIOLÓGICAS DE Danioum maximum JACQ. CV. TOBIATÃ
}

\author{
MOACYR BERNARDINO DIAS FILHO
}

Orientador: Prof. Dr. MOACYR CORSI

\begin{abstract}
Dissertação apresentada à Escola Superior de Agricultura "Luiz de Queiroz", da Universidade de São

Paulo, para a obtenção do título de Mestre em Agronomia. Area de Concentração: Nutrição Animal e Pastagens.
\end{abstract}

$P|R A C| C A B A$

Estado de São Paulo - Brasil

Outubro $=1986$ 
Aos meus pais,

Moacyr e Salomé. OFEREÇO.

Ao saudoso colega,

Ermenson P. Salimos, DEDICO. 


\section{AGRADECIMENTOS}

Ao Professor Dr. Moacyr Corsi por sua contínua orientação, paciência, estímulo e amizade durante o programa de pós graduação e pela revisão do manuscrito deste trabalho.

A Empresa Brasileira de Pesquisa Agropecuária e Centro de Pesquisa Agropecuāria do Trópico Umido pela oportunidade de realização deste programa de pōs-graduação.

A Sueli Cusato, pela amizade, estímulo e constante parti ci pação em todas as fases deste trabalho.

Ao Professor Dr. Irineu Umberto Packer do Departamento de Zootecnia da ESALQ pela amizade e sugestões para à anālise estatistica.

Ao Professor Dr. Ronaldo Ivan Silveira do Departamento de So los da ESALQ pela amizade, sugestões e cessão da casa de vegetação.

Ao Eng : Agro Paulo José Hamakawa e Dr. Paulo L. Libardi do Centro de Energia Nuclear na Agricultura pela determina ção da curva de retenção de ägua do solo e sugestoes na metodologia deste trabaltio. 
i v

Ao colega Eng? Agr? Paulo Ricardo Dias de Oliveira e espo sa pela amizade e colaboração.

Ao colega Dr. Dilson A. Capucho Frazão e família pelo apoio e amizade.

A Sonia Maria Delfini, funcionária do Departamento de Zootecnia da ESALQ pelo apoio e amizade.

Ao Sr. Francisco de Assis Portela, funcionário do Departa mento de Solos, Geologia e Fertilizantes da ESALQ, por sua colaboração espontãnea. 


\section{N D I C E}

Pàgina

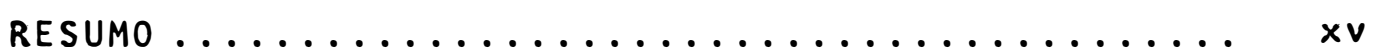

SUMMARY .......................

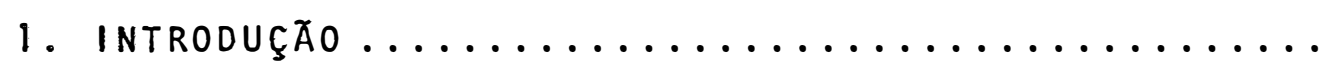

2. REVISÃo de literatura ..................... 3

2.1. Desenvolvimento da planta ............. 3

2.2. Relação raiz:parte aérea ............... 12

2.3. Composição mineral .................. 16

3. MATERIAL E METODOS .................... 22

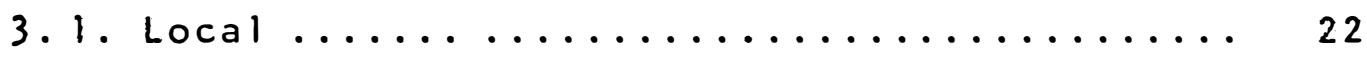

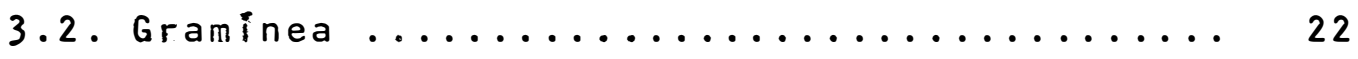

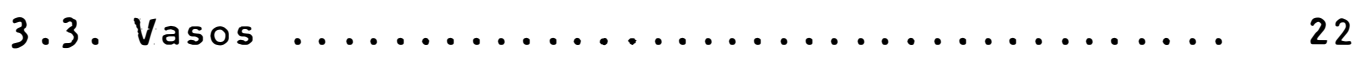

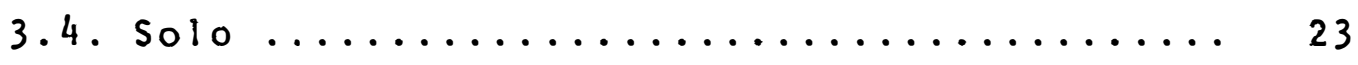

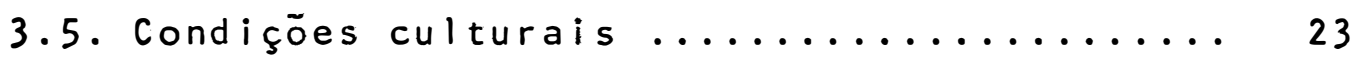

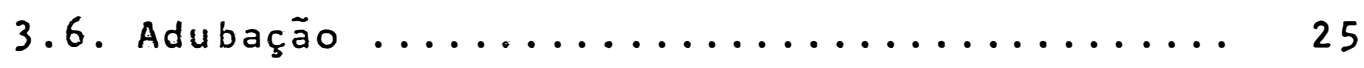

3.7. Delineamento experimental ............ 26

3.8. Regimes de umidade ................. 26

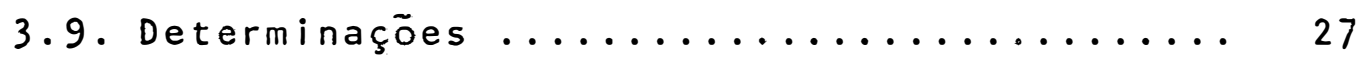

3.9.1. Taxa de extensão foliar ......... 27

3.9.2. Taxa de emergência foliar ....... 28 
Pàgina

3.9.3. Nümero de folhas por planta, numero de folhas por perfilho e número de per

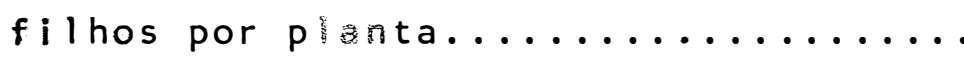

3.9.4. Produção de matéria seca da parte

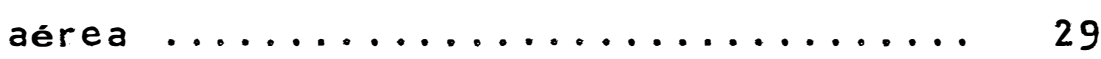

3.9.5. Produção de matéria orgânica da raiz.. 30

3.9.6. Relação raiz:parte aérea......... 30

3.9.7. Composição mineral da parte aérea.... 30

3.9.8. Eficiência do uso de nutriente...... 31

3.10. Anālise estatistica................ 31

4. RESUltados E DISCUSSÃo .................... 33

4.1. Taxa de extensão foliar............... 33

4.2. Taxa de emergência foliar............. 38

4.3. Nümero de folhas.................. 41

4.4. Nümero de perfilhos por planta......... 46

4.5. Produção de matéria seca da parte aérea..... 49

4.6. Produção de matéria orgânica da raiz....... 51

4.7. Relação raiz:parte aérea.............. 53

4.8. Composição mineral............... 55

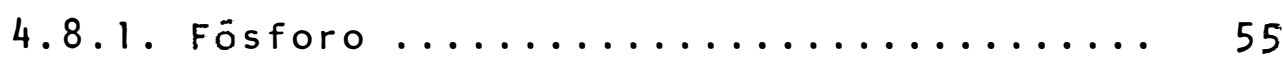

4.8.2. Potássio .................. 62

4.8.3. Càlcio e Magnésio................6 68

4.8.4. Enxôfre................. 71

4.8.5. Eficiência de uso de $P$ e $K \ldots \ldots \ldots 76$ 
Păgina

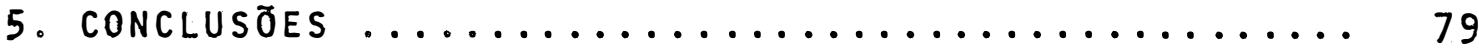

6. LITERATURA CITAdA..................... 82

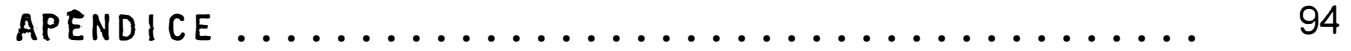




\section{LISTA DE FIGURAS}

Pàgina

Figura 1 - Curva de retenção de agua do solo......

Figura 2 - Taxa de extensão foliar do capim tobiatã sob três regimes de umidade do solo.....

Figura 3 - Distribuição no tempo da emergência de folhas na haste principal do capim tobiatã,sob três regi

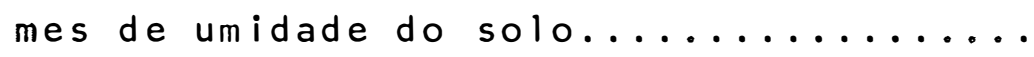

Figura 4 - Número de folhas por planta de capim tobiatã sob três regimes de umidade do solo e em cinco épocas de avaliação......

Figura 5 - Relação raiz:parte aērea de capim tobiatã sob três regimes de umidade do solo e em quatro epocas de avaliação........

Figura 6 - Concentração de fósforo na parte aérea de capim tobiatã sob três regimes de umi dade do solo e em quatro épocas de ava-

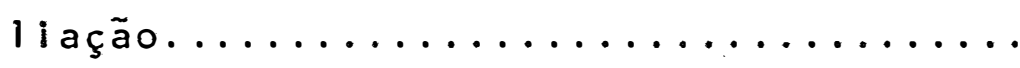

Figura 7 - Conteūdo absoluto de fósforo na parte aérea de capim tobiatã sob três regimes de umidade do solo e em quatro épocas de

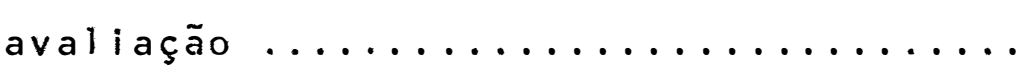


Figura 8 - Concentração de potāssio na parte aérea de capim tobiatã sob três regimes de umidade do solo e em quatro épocas de avaliação...

Figura 9 - Conteúdo absoluto de potássio na parte aérea de capim tobiatã sob três regimes de umidade do solo e em quatro épocas de

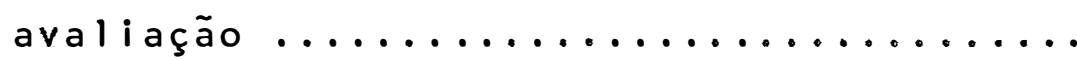

Figura 10-Conteúdo absoluto de cálcio na parte aerea de capim tobiatã sob três regimes de umida de do solo e em quatro epocas de avaliação

Figura 11-Conteúdo absoluto de magnésio na parte aerea de capim tobiatã sob três regimes de umidade do solo e em quatro épocas de ava-

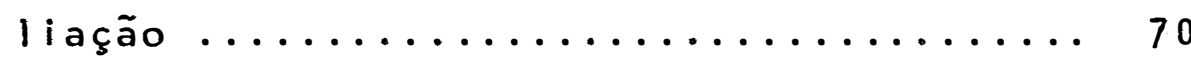

Figura 12- Concentração de cālcio na parte aérea de capim tobiatã sob três regimes de umidade do solo e em quatro épocas de avaliação...

Figura 13- Concentração de magnésio na parte aerea de capim tobiatã sob três regimes de umidade do solo e em quatro épocas de avaliação...

Figura 14-Concentração de enxôfre na parte aérea de capim tobiatã sob três regimes de umidade do solo e em quatro épocas de avaliação... 74 
Pàgina

Figura 15 - Conteūdo absoluto de enxôfre na parte aérea de capim tobiatã sob três regimes de umidade do solo e em quatro épocas

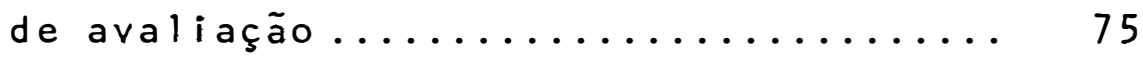

Figura 16 - Eficiência do uso de fósforo e potássio em capim tobiatã sob três regimes de umi dade do solo e em quatro épocas de ava-

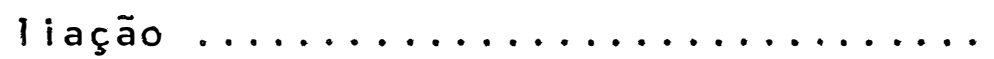




\section{LISTA DE TABELAS}

Pàgina

Tabela 1 - Anālise química do Latossolo Roxo utiliza-

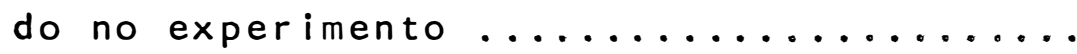

Tabela 2 - Expansão foliar média (cm/dia) de capim To biatã (Panicum maximum cv. Tobiatã) submetido a regimes de umidade do solo (valores relativos entre tratamentos e para o mesmo dia são apresentados em parêntesis)......

Tabel:a 3 - Nümero médio de folhas por planta em épo cas distintas em capim tobiatã(Panicum ma ximum cv. Tobiatä) submetido a três regi-

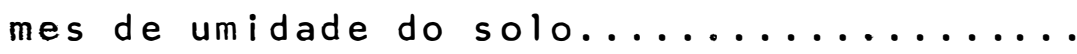

Tabela 4 - Nümero médio de follhas por perfilho por planta em épocas distintas em capim tobiatã (Panicum maximum cv. Tobiatã) submetido a diferentes regimes de umidade do

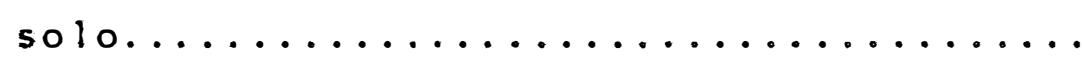

Tabela 5 - Nümero médio de perfilhos por planta em ëpocas distintas em capim tobiatä (Panicum maximum cv. Tobiatãl submetido a diferentes regimes de umidade do solo (valores relativos entre tratamentos são apresentados en-

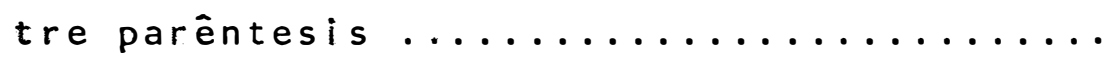


Tabela 6 - Produção de matéria seca da parte aérea e matèria orgânica de raiz em èpocas distintas em capim tobiatã (Panicum maximum cv. Tobiatã) submetido a diferentes regimes de umidade do solo (valores relativos entre tratamentos e para a mesma variável são apresentados entre

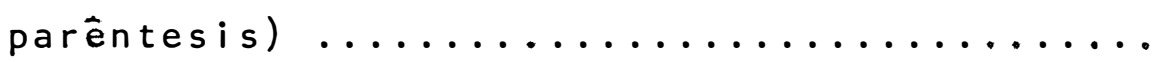

Tabela 7 - Concentração de minerais (\% na matëria seca) em èpocas distintas em capim tobiatá (Panicum maximum cv. Tobiatã) submetido a diferentes

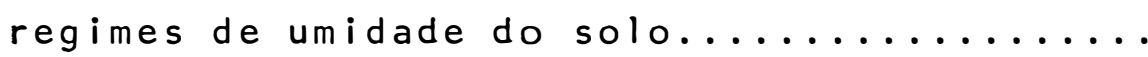

Tabela 8 - Conteūdo (mg na parte aērea) de minerais em épocas distintas em capim tobiatã (Panicum ma ximum cv. Tobiatã) submetido a diferentes re

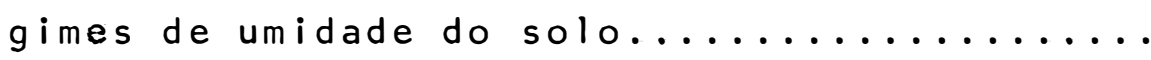

Tabella 9 - Composição média de minerais expressa em concentração (\% na matēria seca) e absorção (mg na parte aèrea) em capim tobiatã (Panicum maximum cv. Tobiatã) submetido a diferentes regimes de umidade do solo (valores relativos para a mesma variável são apresentados entre

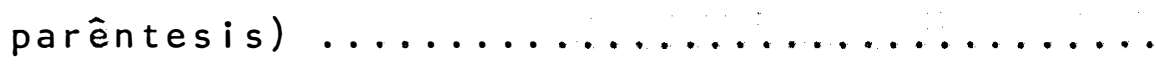


Tabela 10 - Anälise de variância para taxa de expansāo foliar e taxa de emergência foliar....... 95

Tabela 11 - Anālise de variância para peso seco da par te aérea, matēria orgânica da raiz e rela-

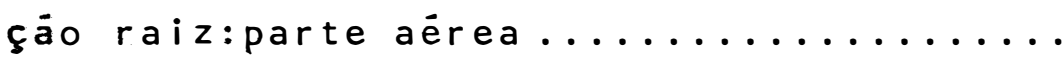

Tabeia 12 - Anālise de variância para número de folhas por planta, nümero de folhas por perfilho e

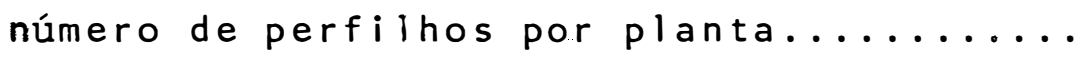

Tabela 13 - Análise de variância para \% de fósforo e mg de fósforo na parte aērea $\ldots \ldots \ldots \ldots$

Tabela 14 - Anālise de variância para \% de potássio e mg de potássio na parte aērea $\ldots \ldots \ldots \ldots$

Tabela 15 - Análise de variância para \% de cālcio e mg de cālcio na parte aérea $\ldots \ldots \ldots \ldots \ldots$

Tabela 16 - Anālise de variância para \% de magnésio e mg de magnésio na parte aérea .......... 101

Tabela 17 - Anālise de variância para \% de enxôfre e mg de enxôfre na parte aērea $\ldots \ldots \ldots \ldots \ldots$

Tabela 18 - Anālise de variância para eficiência do uso de fósforo e eficiência do uso do potàssio $\ldots \ldots \ldots \ldots \ldots \ldots \ldots \ldots \ldots \ldots$ 
EFEITO DO ESTRESSE HTDRICO EM ALGUMAS RESPOSTAS MORFOLOGICAS

E FISIOLOGICAS DE Panicum maximum JACQ. cV. TOBIATÃ

Autor: Moacyr Bernardino Dias Filho Orientador: Prof. Dr. Moacyr Corsi

\section{RESUMO}

o presente trabalho foi conduzido em vasos, sob condições controladas de umidade do solo, na Escola Superior de Agricultura "Luiz de Queiroz", Piracicaba, São Pau 1o, Brasil, objetivando avaliar algumas respostas morfo-fisiológicas do capim tobiatã ao estressehídrico, através do estabelecimento no solo de três regimes distintos de umidade. Foram determinados a taxa de expansão foliar e a taxa de aparecimento foliar, diariamente, em um periodo de vinte e nove dias; o nümero de folhas por planta, nümero de folhas por perfilho e número de perfilhos por planta aos 0,7 , 14,21 e 28 dias de imposição dos tratamentos e; produção de matéria seca da parte aérea, produção de matèria orgânica da raiz, relação raiz:parte aērea e composição mineral da parte aérea aos $7,14,21$ e 28 dias da imposição dos tratamentos. 0 delineamento utilizado foi inteiramente casualizado com três repetições em arranjo fatorial de 
regime de umidade x época $(29,5$.ou 4 épocas) de avaliação os regimes de umidade foram: $U 1$ - capacidade de campo $\quad(45 \%$ de ägua no solo); U2 - estresse hídrico constante (29\% de água no solo) e, U3 - estresse hídrico progressivo (37,,33, 29 e $27 \%$ de água no solo, cada regime de umidade correspon dendo, respectivamente, a um ciclo de sete dias de duração), tendo a necessidade de irrigação sido determinada pela pesa gem, duas vezes ao dia, de cada vaso. 0 solo utilizado foi um Latossolo Roxo Eutröfico (Eutrortox) com curva de retenção de àgua conhecida. Foi feita apenas a adubação de estabelecimento elevando-se o nível de $P$ e K do solo para, respectivamente, 130 e 150 ppm, a lēm da adição de 5 ppm de B, $10 \mathrm{ppm}$ de Fe, $10 \mathrm{ppm}$ de $\mathrm{Mn}, 10 \mathrm{ppm}$ de $\mathrm{Zn}, 5 \mathrm{ppm}$ de Cu e 1 ppm de Mo e 300 ppm de $N$ por vaso.

Dos resultados obtidos è sugerido que o efei to geral médio do estresse hídrico apresentou a seguinte or dem decrescente de intensidade:matēria orgānica da raiz, pe so seco da parte aērea, taxa de expansão foliar, nūmero de folhas por planta, nūmero de perfilhos e nümero de folhas por perfilho. Essas variāveis, respectivamente, para os trạ tamentos U2 e U3, apresentaram os seguintes valores em rela ção a Ul: 58 e 59;59 e 62;71 e 68;75 e 76;79 e 87; e 88 e $96 \%$. 0 conjunto dos efeitos prejudiciais de estresse hídrico sugere que o manejo de utilização da pastagem nestas condições deva ser melhor controlado. Plantas inicial - 
mente submetidas a melhor condição de umidade do solo parecem sofrer mais os efeitos negativos de determinado estresse hidrico do que plantas que já experimentaram esse estres se. A queda na absorção de $C a, M g$ e $S$ seria boa indicadora do estresse hidrico. 
$x v i i i$

\author{
EFFECT OF WATER STRESS ON SOME MORPHOLOGICAL \\ AND PHYSIOLOGICAL RESPONSES OF Panicum \\ maximum JACQ. CV. TOBIATÃ \\ Author: Moacyr Bernardino Dias Filho \\ Adviser: Prof. Dr. Moacyr Corsi
}

\title{
SUMMARY
}

This study was conducted in pots, under controlled water conditions at Escola Superior de Agricultura "Luiz de Queiroz", Piracicaba, São Paulo, Brazil, in order to evaluate some morphological and physiological responses of "tobiatã" grass to soil water stress, by subjecting the plants to three different soil water conditions. Rates of leaf expansion and appearance were followed daily, over a twenty-nine-day period; leaf number per tiller and plant and tiller number per plant were measured at $0,7,14,21$ and 28 days of imposition of soil water conditions and, shoot dry weight and root organic matter production per two plants, root:shoot ratio and shoot mineral content at $7,14,21$ and 28 days of imposition of soil water conditions. The basic treatment design was a factorial combination of soil water condition $x$ period $(29,5$ or 4 periods)of evaluation. A complete randomized design with three replicates was used. 
The soil water conditions were: Ul - field capacity $(45 \%$ of soil water content); U2 - constant water stress ( $29 \%$ of soil water content) and, $U 3$ - progressive water stress $\left(37^{\circ}, 33\right.$, 29 and $27 \%$ of soil water content, each soil water condition corresponding, respectively, to a 7-day cycle). The soil water content. was maintained by weighting the pots twice a day and adding sufficient water to provide the desired weight. The soil was a "Latossolo Roxo Eutrófico" (Eutrortox) with known moisture retention curve. Each pot, before planting, had the $P$ and $K$ levels $r i s e n$, respectively, to 130 and 150 ppm, receiving also 5 ppm of $B, 10$ ppm of $\mathrm{Fe}, 10 \mathrm{ppm}$ of $\mathrm{Mn}$, $10 \mathrm{ppm}$ of $\mathrm{Zn}, 5 \mathrm{ppm}$ of $\mathrm{Cu}, 1 \mathrm{ppm}$ of Mo and $300 \mathrm{ppm}$ of $N$.

\section{From evidences obtained it is suggested that} the average overall effect of water stress produced the following decreasing order of intensity: root organic matter, shoot dry weight, leaf expantion rate, leaf number per plant, tiller number per plant and leaf number per tiller, with relative values, respectively, to U2 and $U 3$ of 58 and 59 ; 59 and $62 ; 71$ and $68 ; 75$ and $76 ; 79$ and 87 , and 88 and $96 \%$ of Ul values. The deleterious water stress effects suggest that the pasture management utilization under these conditions should be better controlled. Plants firstly subjected to a particular water stress appear to be more affected than plants which were already experiencing this stress. A fall on $\mathrm{Ca}$, Mg and $\mathrm{S}$ uptake would be a good indication of water stress. 


\section{INTRODUŞ̃̃O}

Periodos intermitentes de déficite hídrico po dem ser considerados os maiores limitantes climäticos para o crescimento de gramineas forrageiras em ambiente de clima tropical.

No Brasil, de modo especial, na Amazônia brasileira, grande parte das àreas de pastagens cultivadas estão localizadas em regiões sujeitas anualmente a períodos variāveis de seca que ocasionam comprometimento da produção destas pastagens e, consequentemente, da produção animal sus tentada por elas.

Neste período o manejo da pastagem deve objetivar o minimo possivel de queda de produtividade, garantindo assim uma rápida recuperação e manutenção desta produtivida de com o restabelecimento das condições hidricas ideais.

$$
\text { Sabe-se, no entanto, que uma importante causa }
$$


de declinio de produtividade de pastagens cultivadas é o manejo inadequado no inicio, durante e ao final do período seco, sendo portanto uma fase critica para a manutenção de uma composição botânica adequada no pasto, fator que irà garantir maior longevidade produtiva da pastagem.

0 conhecimento do comportamento morfo-fisiológico da forrageira submetida a estresse hidrico tornase portanto uma importante ferramenta para entender e tornar capaz de predizer os efeitos do estresse hidrico na pro dução da planta e da pastagem, possibilitando assim o uso de práticas de manejo que tornem possivel uma melhor utilização da pastagem durante esta fase.

0 presente trabalho tem como objetivos:

a) Possibilitar o entendimento, em bases mor folögicas e fisiolögicas, de algumas características do com portamento da forrageira testada nas condições de estresse hidrico.

b) Propor sugestões de manejo visando o aumento da longevidade produtiva das pastagens em condições de estresse hidrico. 


\section{REVISÃO DE LITERATURA}

\subsection{Desenvolvimento da planta}

Com o aumento da transpiração, mesmo estando - solo na capacidade de campo, o potencial de água da planta diminui se a capacidade das raizes em extrair água do solo e a taxa de transporte de água para as folhas não consegue suprir a demanda atmosférica, levando as folhas a experimentarem um déficite de água. Havendo perda de água do solo, o déficite se torna mais severo e duradouro (PEAKE et alii, 1975), pois o transporte de àgua para as raízes diminuiria devido ao decréscimo na condutividade do solo e contato entre o solo e as raízes (BOYER, 1985).

HSIAO e ACEVEDO (1974) advertem que as plantas säo organismos altamente integrados e, à medida que o estresse afeta algum processo na planta, vários mecanismos de controle podem ser ativados visando ajustar outros processos para manter um equilibrio ou fazer frente ao proble 
ma. O estresse hidrico afeta todos os aspectos do crescimen to da planta, incluindo a anatomia, morfologia, fisiologia e bioquimica (KRAMER, 1983). TURNER e BEGG (1978) mostram que respostas morfológicas como perfilhamento, desenvolvimento da área foliar e crescimento radicular são mais sensíveis ao dēficite hídrico que os processos fisiológicos.

E fato já amplamente aceito que a redução no crescimento celular é um dos efeitos mais imediatos provoca do pelo estresse hídrico (HSIAO, 1973; HSIAO e ACEVEDO, 1974; LEVITT, 1980; TURNER e BEGG, 1981), sendo que outros proces sos menos sensíveis são afetados posteriormente, com o aumento da severidade do estresse (BEGG, 1980). 0 efeito do es tresse hídrico na redução do crescimento celular seria, segundo värios autores (RITCHIE, 1974; HSIAO e ACEVEDO, 1974; LEVITT, 1980), primariamente de natureza fisica, ou seja, uma redução na pressão hidrostática necessāria para a expansão celular devido à queda do potencial de água celular causada pela desidratação. Esta pressão exercida pela turgidez celular teria influência direta na taxa de crescimento do órgão em expansão, suprindo a pressão interna necessária para expandir as paredes celulares nos tecidos em crescimento (BOYER, 1970; HSIAO, 1973; BOYER, 1985).

Segundo WATTS (1974), em gramíneas a elongação da folha seria controlada pela condição de água da região embrionária na base das folhas, podendo ser portanto 
muito diferente das condições de umidade das regiões mais velhas e expostas das partes centrais e terminais. Sendo as sim, em gramineas, a expansão foliar não seria necessariamen te relacionada à turgidez geral da folha. De fato, estudo de Barlow et alii, citado por KRAMER (1983) também enfati-za que em gramineas a expansão foliar não seria necessariamente relacionada com a turgidez geral da folha.

Alguns trabalhos (HSIAO, 1973; KLEINENDORST, 1975; LUDLOW e NG, 1977; HUMPHREYS, 1981) têm demonstrado que a divisão celular nas folhas é menos sensivel ao estres se hídrico que a expansão celular, havendo, com o aumento do estresse, um decréscimo mais lento da taxa de divisão, cessando, provavelmente, em potencial de ägua mais baixo que a extensão celular. No entanto, têm sido demonstrado que, dependendo da espécie, os efeitos primários de um estresse hidrico fraco a moderado podem ser atuantes na fase de expansão celular ou tanto na fase de divisão e expan são celular do crescimento da follha (BEGG e TURNER, 1976).

Assim é que ao verificar os efeitos de ciclos curtos de estresse hidrico no crescimento de Panicum maximum var. trichoglume, em vasos, sob condições controladas, NG et alii (1975) observaram que o estresse hídrico reduzit o crescimento da planta e atrasou o desenvolvimento vegetativo (haste) e reprodutivo (flor). O efeito observado no crescimento resultou de uma redução na atividade (taxa de assimilação líquida) e tamanho relativo (ārea) da super- 
fície fotossintética. A redução na taxa de assimilação lí quida foi a principal determinante da mais baixa taxa de crescimento relativo das plantas estressadas desta gramínea nos ciclos iniciais de estresse, mas em sequência, com a redução na ārea foliar, a taxa de ārea foliar também teve uma influência significativa. Neste experimento é ainda mos trado que o crescimento de $P$. maximum foi afetado de duas mạ neiras, uma direta através da influência no processo de cres cimento e a outra indireta, pela influência no desenvolvi mento da planta ou ontogenia. Um decréscimo de -8 para -10 bars encontrado no valor do potencial de água da folha, para provocar murchamento, foi interpretado por estes autores como uma resposta de adaptação nas plantas que haviam sido expostas a um maior número de ciclos de estresse hídrico.

Em uma revisão sobre a dinâmica da água no sistema solo-planta-atmosfera, RITCHIE (1981), fazendo uma anālise da influência da água passivel de extração do solo sob a taxa relativa de vários processos fisiológicos, afirma que o processo de elongação foliar é mais sensivel ao déficite de água que outros processos, sendo que a elongação pạa ra, mesmo quando alguma água permanece no solo.

CHU et alii (1973) ao submeterem Bromus catharticus a periodos de estresse hidrico observaram que a taxa de expansão foliar começou a decrescer três dias após a imposição do estresse hidrico, continuando a cair rapida- 
mente, chegando a niveis de $7 \%$ da taxa de expansão do trata mento sem estresse no 28 ? dia.

Estudando o efeito do estresse hidrico no crescimento do milho, ACEVEDo et alii (1971) reportaram que a expansão das folhas de milho foi altamente sensivel a pequenas reduções no potencial de água do solo e que a resposta da extensão foliar à queda do conteúdo de agua do solo é dinâmica, com a taxa decrescendo continuamente à medida que o potencial de água do solo decrescia de um máximo. E mencionado ainda que, com o desenvolvimento do estresse, a expansão pára completamente antes que a assimilação de $\mathrm{CO}_{2}$ seja notadamente afetada.

Da mesma forma, WARDLOW (1969) encontrou que em Lolium tremulentum sujeito a deficiência de água havia uma redução no crescimento de expansão das raizes e folhas novas antes de haver qualquer efeito na fotossintese da fo1ha. BOYER (1970) menciona tambèm a mesma tendência em miIho, soja e girassol submetidos a diferentes intensidades de estresse hidrico

LUDLOW e NG (1976) mostraram que a taxa de expansão foliar de $P$. maximum var. trichoglume decresceu com o decréscimo do potencial de água da planta. Porém, ao contrário dos resultados do estudo com outras espécies, a fotossintese liquida e a expansão de $P$. maximum parecem ter tido o mesmo grau de sensitividade ao estresse de água. 
Decréscimos nas taxas de expansão foliar motivados por pequenas quedas no potencial de ăgua das folhas foram indicados por LAWLOR (19úg) ao estudar feijão, algo dão, milho e Lolium perenne por duas semanas em solução de potencial osmótico controlado. Comenta ainda LAWLOR (1969) que todos os aspectos do crescimento foram diminuídos pelo decréscimo no potencial osmótico do meio radicu lar, tendo o peso seco total de todas as espécies, a cada colheita, decrescido.

Para värias gramíneas tropicais cultivadas em vasos sob quatro niveis fixos de suprimento de ăgua, houve, com o decréscimo na umidade do solo, uma grande redução no peso seco da parte aérea, independente do estädio de desenvolvimento da planta. Em P. maximum, por exemplo, com oito semanas de idade, o decréscimo no peso seco da parte aérea foi de $38 \%$ em relação ao tratamento com maior nível de àgua (ABDEL RAHAMN et alii, 1971; GERAKIS et alii (1975) encontraram também redução na matéria seca total (biomassa) de Erodium botrys, Bromus mollis e Trifolium subterraneum em condições controladas, sujeitos a estresse de umidade do so 10. Resultados semelhantes foram também encontrados para diferentes cultivares de alfafa por CARTER et alii (1982), soja por KRIZEK et alii (1985) e Lupinus albus por WITHERS e FORDE (1979). 
Segundo MCCREE e DAVIS (1974) a taxa de produção de matéria seca é bastante afetada pela área foliar. tendo sido observado em sorgo granifero (Sorghum bicolor) que a taxa de crescimento e a área foliar final decresceram progressivamente com o aumento do estresse de calor e água. De acordo com BADE e CONRAD (1985) al tas temperaturas podem exage rar o efeito do estresse hídrico mediante o aumento da taxa de evapotranspiração, reduzindo consequentemente a produção devido o estresse hidrico.

o grau de redução do crescimento e produção causado pelo déficite hídrico através da diminuição da área foliar depende da relação entre taxa de extensão e potencial de água da folha durante o estresse e na recuperação apōs a chuva ou irrigação (HSIAO, 1973). O estresse de āgua pode também afetar a área foliar através da aceleração no processo de morte de folhas e perfilhos (TURNER e BEGG, 1978). Sob estresse hidrico as folhas novas se desenvolvem mais lentamente (aumento do plastrocromo) e as folhas velhas senescem mais rapidamente, existindo assim uma séria redução na área fotossintética assim como uma redução da tạ xa de fotossintese por unidade de área foliar (KRAMER,1983).

Sabe-se que o estresse hidrico acelera a morte das folhas velhas, porém, deve ser lembrado que o momento quando o estresse ocorre e o estágio de desenvolvimento da 
folha estão tambēm ligados a senescência em gramineas tropi cais (WILSON e MANNETJE, 1978). Assim é que o estresse hidrico acelerou a morte de folhas mais velhas em plantas de P. maximum var. trichoglume quando comparada com as plantas do tratamento testemunha (NG et alii, 1975). KRAMER (1983) explica que, em plantas sob estresse hidrico, as folhas novas competem por água com as folhas mais velhas, as quais com frequência morrem prematuramente devida a dissecação.

CORLETO e LAUDE (1974) cultivaram L. perenne em solo que teve o teor de umidade reduzido para $7 \%$, sendo então irrigado neste ponto ou oito dias após. As plantas submetidas à segunda alternativa apresentaram, sete semanas depois, diminuição de $33 \%$ no peso seco da parte aérea e $45 \%$ no peso seco das raízes.

Ao avaliar o comportamento de duas espécies de urochloa por um período de três anos, em clima sujeito a periodos de seca, McIVor (1984) observou que as mudan ças nas taxas de aparecimento foliar foram intimamente relacionadas a mudanças no conteúdo de umidade do solo, sendo maior ( 2 folhas por perfilho por semana) após as chuvas.

Geralmente o perfilhamento é reduzido pelo estresse hidrico (LANGER, 1963; TURNer e BEGG, 1978). Expe rimento relatado por. LUXMOORE et alii (1971) mostrou que 
um menor suprimento de água no solo provocou a diminuição no nümero de perfilhos em $L$. perenne, tendo esta variável sido a principal resposta morfológica associada com a produção de matéria seca e a àrea foliar. Neste estudo, o número de folhas por perfilho, tanto para folhas novas ou expandidas não foi influenciado pelo estresse hídrico.

NORRIS (1982) encontrou que déficites crescentes de ägua tiveram um menor efeito no nūmero de perfilhos que na expansão foliar de Lolium, Dactylis e Festuca. Redução no perfilhamento devido ao estresse hídrico foi tam bém observada por CHU et alie (1979) em B. catharticus.

L. perenne e L. multiflorum submetidos a estresse hídrico apresentaram redução do nümero de perfilhos por planta da ordem de $29 \%$ em mëdia, em relação ao trata mento testemunha (NORRIS e THOMAS, 1982). De maneira semeIhante BADE e CONRAD (1985) relataram diminuição, devido ao éstresse hídrico, no número de perfilhos por planta da ordem de $20 \%$ e $46 \%$ para Cynodon dactylon e Panicum coloratum, respectivamente, tendo esta variável tido maior influência que o peso individual do perfilho na redução da produção de matéría seca observada nas plantas sob estresse hídrico. Contrariamente, NG et alii (1975) observaram que o nümero de perfilhos de $P$. maxímum var. trichoglume não muito foi afetado pelo estresse hidrico. 


\subsection{Relação raiz:parte aérea}

A influência do estresse de àgua no cresci mento da raíz é um assunto de certa forma controvertido. GA LES (1979) revisou 28 trabalhos sobre o efeito do estresse hídrico na relação raiz:parte aérea em diferentes plantas. 0 estresse hidrico aumentou a relação em 19 casos, diminuiu em quatro, não teve efeito em três e foi variāvel em dois. Este autor sugere que os resultados conflitantes obtidos po dem ser atribuídos a diferenças no estädio de crescimento das plantas e a possíveis variações na disponibilidade de nutrientes. De fato, de acordo com OZANNE (1980), plantas sob condições de deficiência de fósforo podem apresentar uma diminuição no crescimento da parte aérea em relação à raiz, caracteristica que poderia ser em parte motivada pela condição mais favorāvel de fósforo das raízes pois apresentam oportunidade inicial de metabolizar o fósforo absorvido. Também, conclui este autor, existe provavelmente uma vantagem evolucionária em sobrevivência e crescimento da planta que apresenta um sistema radicular maior e mais extenso sob condições de baixa disponibilidade de fósforo.

Muito embora, conforme mostram BEGG e TURNER (1976) e TURNER e BEGG (1978) a relação raiz:parte aērea possa aumentar com a intensificação do estresse hídrico, não está claro se isto representa um aumento absoluto no 
peso da raiz ou apenas um menor efeito do estresse na raiz que na parte aérea. Existem casos, no entanto, em que o estresse de umidade provocou efeitos distintos no crescimento da raíz, como no trabalho de GERAKIs et alii (1975) em Erodium botrys, Bromus mollis e Trifolium subterraneum sob diferentes condições de umidade do solo em casa de vegeta çao. o crescimento da raiz de todas espécies foi diminuido pelo aumento do estresse de umidade. Já no experimento de senvolvido por PEACOCK e DUDECK (1985), nenhum efeito de tratamento (intervalo de irrigação) foi observado na distrí buição de raiz de Stenotraphrum secundatum em condições de campo.

No entanto, vários autores (HSIAO e ACEVEDO, 1974; BEGG, 1980; PASSIOURA, 1981) apresentam evidências que o estresse hidrico aumenta o crescimento da raiz não somen te relativo ao crescimento da parte aérea, mas de uma for ma absoluta. A explicação oferecida é que o estresse, sendo insuficiente para afetar de maneira marcante a assimilação de $\mathrm{CO}_{2}$, apesar de afetar o crescimento da parte äerea, provocaria um ajuste osmötico e crescimento extra da raíz devi do ao aumento de assimilados resultante do reduzido crescimento da parte aérea. De maneira semelhante, WESTGATE e BOYER (1985) inferiram que o aumento geralmente observado na relação raiz:parte aérea em condições iimitantes de àgua poderia ser explicado pela mais eficiente manutenção da tur 
gidez e gradiente de potencial de água apresentado pelas raizes em relação às folhas, o que provavelmente permitiria a continuidade de crescimento da raiz.

Em uma revisão de literatura, TURNER e BEGG (1981) mostram que o aumento da relaçãoraiz:parteaéreaobser vada em muitas culturas e forrageiras poderia resultar simplesmente de uma maior diminuição relativa do peso seco da parte aérea, sendo porém bem mais provável que o aumento desta relação resultasse da maior alocação do limitado carbono disponível para as raízes, e não para a parte aérea, com o desenvolvimento do estresse hídrico. Proposição esta tambèm compartilhada por COOPER (1983) e demonstrada por KRIZEK et alii (1985) em soja cultivada em condições contro ladas e submetida a estresse hídrico. Esta maior alocação, segundo TURNER e BEGG $(1981)$, seria particularmente importante na fase vegetativa, sendo a consequência da maior sen sitividade da expansão foliar que da fotossíntese ao estres se hídrico. Este último aspecto também foi demonstrado por WARDLOW (1969).

Em P. maximum var. trichoglume sujeito a periodos curtos de estresse hidrico, NG et alii (1975) discutem que as mais baixas taxas de desenvolvimento e expansão de folhas e seus menores pesos secos, juntamente com um deslocamento preferencial do carbono fixado para a raiz, resultaram em menores relações de peso parte aērea:raíz. 
SHARP E DAVIS (1973) reportaram que plântulas de trigo, em vasos, sujeitos a deficiência de água, mos traram um substancial aumento absoluto no crescimento da raiz, tanto no comprimento total como no peso seco do sistema radicular. Também com trigo, experimento de campo conduzido por PROFFITT et alii (1985) indicou que a alta frequência de irrigação produziu um sistema radicular mais raso que na menor frequência de irrigação.

Uma clara demonstração de que o estresse hídrico pode induzir um enraizamento mais desenvolvido foi feita por MALIK et alii (1979) onde plântulas de algodão foram cultivadas em solo sob diferentes conteūdos de ägua e o crescimento das raízes ém solução nutritiva, abaixo da camada do solo foi examinado. As raízes emergiram das camadas de solo mais rapidamente e exibiram maior taxa de elongação após emergência, quanto menor era o conteúdo de água do solo.

Em um estudo onde investigou-se a influência do déficite hídrico do solo na dinâmica do desenvolvimento da raìz e absorção de água por plantas de milho, não foi ob servado aumento do peso seco das raizes nos tratamentos com estresse, mas sim uma mudança na distribuição da raiz no perfil do solo (SHARP e DAVIS, 1985). 
Em L. perenne cultivado em ambiente controla do sob niveis de baixa umidade do solo foram encontradas maiores relações raiz:parte aérea nas avaliações feitas entre 13 e 23 dias após a germinação, tendo esta tendência se invertendo na avaliação feita aos 29 dias (GALES, 1979). Infere este autor que quando a àgua é limitada, a relação raiz: parte aérea pode ser influenciada mais por um decréscimo na disponibilidade de nutrientes minerais, principalmente o fósforo, do que pela disponibilidade de água do solo. Em al gumas situações, conclui GALES (1979), aumentos nas relações raiz:parte aérea em plantas submetidas a estresse hídrico estão associadas a baixos níveis de fósforo no solo ou baixas concentrações deste nutriente no tecido da planta.

\subsection{Composição mineral}

A necessidade da água para o transporte de nutrientes à planta é fato de reconhecida importancia. Conforme comenta MARSCHNER (1983), o decréscimo no potencial

de água do solo afeta não somente a absorção de água pela planta e o contato entre raízes e solo, mas também a taxa de difusão de íns para a superfície da raiz, além de afetar, conforme VIETS (1972), o fluxo de nutrientes na ägua quando esta água é absorvida pela raiz.

\footnotetext{
Dando mais detalhes aos comentários acima,
} 
KRAMER (1983) discute que, devido à existência de um movi mento a longa distância da raíz à parte aérea ocorrer no fluxo de transpiração, uma redução na taxa de transporte de ions pode ocorrer em plantas que têm a transpiração reduzida pelo estresse. A absorção de ions pode também ser reduzi da devido ao movimento de minerais ser lento em solo com baixa umidade, a extensão radicular ser diminuida, e a sube rização decrescer a permeabilidade da raiz. De fato, HSIAO (1973) comenta que, para plantas em condições de campo, as mudanças no solo causadas pela diminuição do conteūdo de água podem ser tão pronunciadas que encobririam os efeitos do estresse hidrico na absorção e transporte de minerais pẹ la planta.

Revendo a literatura, HSIAO (1973) afirma que vários experimentos têm demonstrado que altas taxas de transpiração podem aumentar a absorção de íons pelas raí zes, sendo este efeito mais pronunciado se as raízes já con têm altos niveis de nutrientes e se a concentração do íon no meio externo é alta.

De acordo com PITMAN (1981), o fluxo de água no solo terá maior importância relativa para íons como o fosfato que possuem um baixo coeficiente de difusão no solo. Discute ainda este autor que a redução na umidade do solo afeta a concentração relativa de solutos no solo. Sendo assim, ions como $\mathrm{Cl}^{-}$ou nitrato, que são pouco adsorvidos nas 
partículas do solo, aumentam em concentração, assim como hạ verá um aumento equivalente, na concentração total de cátions como $\mathrm{K}^{+}, \mathrm{Na}^{+}, \mathrm{Ca}^{2+} \mathrm{e} \mathrm{Mg}^{2+}$. Finalmente, conclui PITMAN (1981), ions que estão fortemente adsorvidos ou em equilíbrio químico com sais insolüveis tenderão aumentar em concentrações no solo, com consequente possiveis influências na absorção pela planta.

Investigações sobre o efeito do estresse de umidade no acúmulo de nutrientes em tecidos vegetais são, em alguns casos conflitantes. VIETS (1972) generaliza que para um dado nível de fertilidade, o decréscimo do suprimento de umidade do solo é associado com um aumento definido no conteúdo de nitrogênio total do tecido vegetal, um decreścimo definido no conteūdo de potássio, e um efeito variável no conteūdo de fósforo, cálcio e magnésio.

Revisão de literatura feita por Vaadia et alie (1961), citada por GERAKIS et alie (1979), sustenta que o estresse hídrico promove um decréscimo nas concentrações de fósforo e potássio no tecido da planta afetada. Decrēscimo na concentraçãodefósforo da planta associado à baixa disponibilidade de àgua do solo, tambèm é mencionado por Peasant e Dionn (1976), citados por WILSON (1981); SHARPLEY e REED (1982) e WILSON (1982).

KRIZEK et alii (1985) relataram uma redução superior a $40 \%$, na concentração de fósforo acumulado nas fo 
Ihas, hastes e raizes de soja submetida a estresse de umida de do solo. Esta redução na concentração de fósforo seria fruto de perturbação fisiológica que poderia finalmente ser refletida através da menor produção de matéria seca.

Em cebola, a absorção de fósforo foi muito mais sensivel ao estresse hídrico que a absorção de potás sio, magnésio e cálcio (Dunham e Nye, 1976, citados por LEVITT, 1980). MAERTENS (1981) demonstrou que a irrigação promoveu aumento na absorção de nitrogênio, fósforo e potás sio em girassol, L. perenne e alfafa, com menos efeito no nitrogênio.

Para algumas gramineas e leguminosas submet das a estresse hidrico foi encontrado que o estresse provocou no tecido vegetal um acúmulo de ions como $\mathrm{K}^{+}, \mathrm{Na}^{+}, \mathrm{Ca}^{2+}$, $\mathrm{Mg}^{2+}$ e $\mathrm{Cl}^{-}$, havendo no entanto um decréscimo para fósforo e ferro (ABDEL RAHMAN et alii, 1971). Tendência semelhante foi óbservada em gramineas forrageiras $C_{3}$ e $C_{4}$, onde tanto a concentração no tecido da planta, como a absorção de $P$ e K decresceram com o aumento do estresse de umidade do solo (MISRA E SINGH, 1982).

Em sorgo granifero submetido a estresse hidrico houve um decréscimo na concentração do fósforo e nenhuma influência no potássio, cálcio e magnésio no tecido da planta (ECK e MUSICK, 1979). Em milho cultivado a campo, recebendo ou não irrigação, o conteúdo de $K$ das plantas 
nao irrigadas caiu, possivelmente, devido à senescência das folhas, mas Ca e Mg aumentaram relativamente mais nas plantas que apresentaram maior grau de transpiração, jā que a absorção destes ions pode ser proporcional ao fluxo de àgua na planta (PITMAN, 1981).

E sabido que o estabelecimento de um baixo potencial osmötico permite que a planta se adapte a condi ções de estresse hídrico mediante o desenvolvimento de baixos potenciais de àgua, evitando o fechamento prematuro dos estômatos e consequente redução no crescimento (TURNER e BEGG, 1978; PITMAN, 1981; MORGAN, 1984). De acordo com PITMAN (1981) as plantas têm duas estratégias para manter o conteūdo osmōtico: uma é a absorção de íons do solo (para a formação de solutos inorgânicos) e a outra seria a formação de solutos orgânicos.

Em um estudo de adaptação ao estresse hídrico de quatro forrageiras tropicais WILSON et alie (1980) en contraram que o acümulo de solutos foi a förmula de ajuste osmötico das folhas ao estresse hidrico.

Algumas pesquisas têm demonstrado que solutos inorgânicos como o potássio, södio e cloro acumulam em determinadas plantas submetidas a estresse hidrico devido ao papel destes íons como reguladores osmöticos em muitas espécies (CUTLER et aliei, 1977;.CUTLER e RAINS, 1978; FORD e WILSON, 1981). 
De acordo com VIETS (1972) nas avaliações de minerais no tecido da planta devem ser expressas tanto a concentração como a absorção total (valor absoluto) do nutriente a fim de tornar completas as interpretações em estudos com estresse hidrico. No caso da absorção total do elemento, se o estresse hidrico diminui o crescimento e o conteúdo total do nutriente também decresce, significa que o estresse estaria diminuindo a disponibilidade do nutriente. Já um aumento na composição percentual de um mineral. com o aumento do estresse, pode ser considerado como sendo uma absorção deste nutriente a uma taxa mais rápida que o aumento do peso seco. 0 estresse hidrico estaria inibindo o crescimento mais que a absorção de nutriente. Um decréscimo na composição percentual significa que a assimilação líquida e o crescimento não foram tão afetados quanto a disponibilidade do nutriente. 


\section{MATERIAL E METODOS}

\subsection{Local}

$$
0 \text { experimento foi conduzido em casa de vege- }
$$
tação do Departamento de Solos, Geologia e Fertilizantes da Escola Superior de Agricultura "Luiz de Queiroz", em Piraci caba, SP., sob condições controladas de umidade do solo.

\subsection{Graminea}

A graminea utilizada foi o capim tobiatã (Pa nicum maximum Jacq. cv. Tobiatã), oriundo do Instituto Agronômico de Campinas, SP.

\subsection{Vasos}

Foram utilizados vasos plästicos, sem dreno, com volume total de $5.000 \mathrm{ml}$, diàmetro superior e inferior 
de, respectivamente, $23 \mathrm{~cm}$ e $17,5 \mathrm{~cm}$ e altura de $19 \mathrm{~cm}$. $0 \mathrm{~s}$ vasos foram revestidos interna e externamente com sacos de polietileno de coloração preta.

\subsection{Solo}

Cada vaso continha $4 \mathrm{~kg}$ (peso seco ao ar) de um Latossolo Roxo Eutrófico (Eutrortox) passado em peneira de $2 \mathrm{~mm}$ de malha, tendo densidade global de $1,029 \mathrm{~g} / \mathrm{cm}^{3}$, apresentando curva de retenção de ägua conforma a Figura l e com características quimicas descritas na Tabela 1.

Tabela 1. Análise química do Latossolo Roxo utilizado no experimento

\begin{tabular}{cccccccc}
\hline $\begin{array}{c}\mathrm{PH} \\
\left(\mathrm{H}_{2} \mathrm{O}\right)\end{array}$ & $\begin{array}{c}\mathrm{C} \\
\%\end{array}$ & $\begin{array}{c}\mathrm{P} \\
\mathrm{ppm}\end{array}$ & $\begin{array}{c}\mathrm{K} \\
\mathrm{ppm}\end{array}$ & $\begin{array}{c}\mathrm{Ca} \\
-\end{array}$ & $\mathrm{Mg}$ & $\mathrm{Al}$ & $\mathrm{H}$ \\
\hline 5,8 & 0,78 & 4,0 & 11,7 & 4,00 & 0,89 & 0,16 & 4,16 \\
\hline
\end{tabular}

\subsection{Condiçōes culturais}

o capim tobiatã foi inicialmente semeado em areia em 20.I.86, tendo em 7.II.86 (após o aparecimento de terceira folha) sido transplantado na proporção de três plântulas por vaso, sofrendo em $24 . I I .86$ desbaste para duas plântulas por vaso, selecionadas pelo nümero de folhas e uniformidade de altura. 


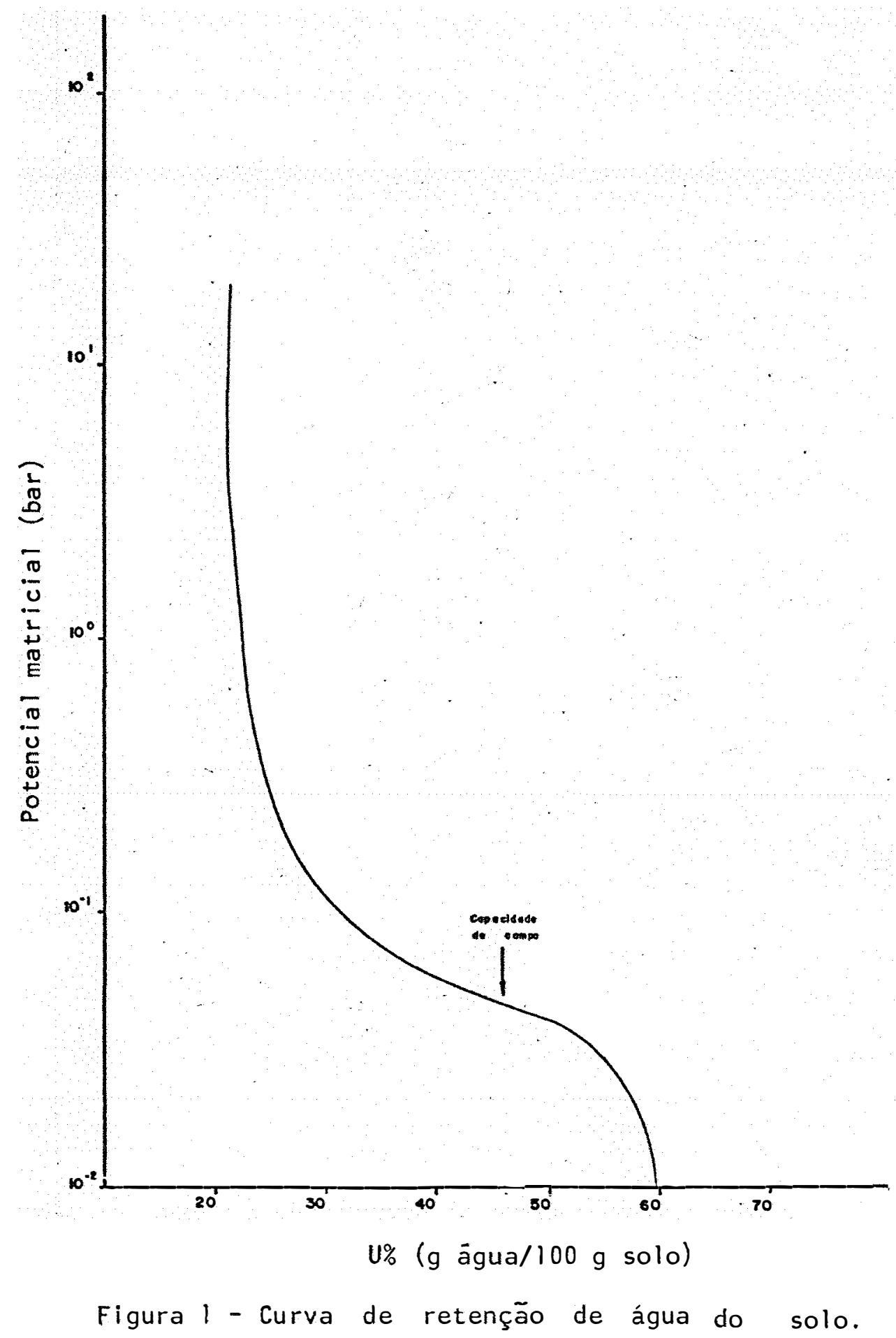




\subsection{Adubaçāo}

Antes do transplante cada vaso recebeu uma adubação equivalente a:

- Elevação dos níveis de $P$ e do K do solo pạ ra 130 ppm e 150 ppm, respectivamente, tendo sido utiliza dos superfosfato simples e cloreto de potássio como fonte de cada elemento.

- Adição de 5 ppm de B, 10 ppm de Fe, 10 ppm de Mn, 10 ppm de Zn, 5 ppm de Cu e l ppm de Mo, utilizandose uma mistura formada por: Acido börico, sulfato ferroso, sulfato de manganès, sulfato de zinco, sulfato de cobre e molibdato de sódio.

Imediatamente após o desbaste $(17$ dias após

o transplante), quando a maioria das plantas já apresentạ vam o segundo perfilho, foi feita a adubação nitrogenada, aplicando-se ao solo $300 \mathrm{ppm}$ de $N$ por vaso na forma de uréia em solução aquosa.

Sete dias apōs a adubação nitrogenada foi fẹ ta aplicação foliar de solução de $0,5 \%$ de sulfato de zinco mais $0,3 \%$ de carbonato de cálcio visando combater uma poss I vel deficiência generalizada de zinco nas plantas. 


\subsection{Delineamento experimental}

o experimento foi conduzido usando um delineamento experimental inteiramente casualizado em arranjo fatorial com três repetiçōes. Os fatores foram regime de umidade do solo (Capacidade de campo, Estresse 1 e Estresse 2) e época de avaliação $(7,14,21$ e 28 dias para as variáveis produção de matéria seca da parte aérea, produção de matéria orgânica da raíz, relação raiz:parte aérea, composição mineral da parte aérea e eficiência do uso de nutrientes; $0,7,14,21$ e 28 dias para as variáveis número de folhas por planta, número de folhas por perfilho e número de perfilhos por planta, ou diariamente do 19 a 289 dia para as variáveis taxa de extensão foliar e taxa de emergência foliar).

\subsection{Regimes de umidade}

Do transplante até o início da imposição dos regimes hidricos (23 dias) o solo de todos os vasos foi mantido a $45 \%$ de água, aproximadamente a capacidade de campo.

Os regimes experimentais de umidade iniciaram seis dias após a adubação nitrogenada, quando a haste principal da maioria das plantas já havia emitido a oitava folha, tendo este dia sido designado dia 0 (zero). 
Os regimes de umidade impostos foram os se-

guintes:

Capacidade

solo mantido aproximadamente à capacidade de de campo

(UI): campo ( $45 \%$ de água) por todo o período experimen tal (28 dias).
Estresse hídrico solo mantido a $29 \%$ de agua, por todo o período cons tante experimental.

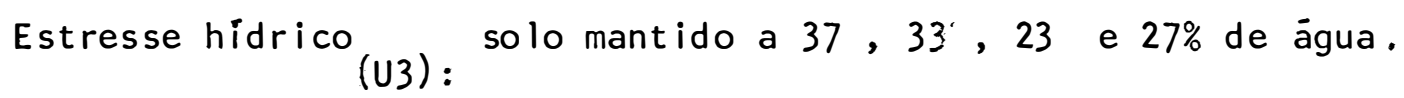
progressivo

Cada regime de umidade correspondendo, respec tivamente, a um ciclo de sete dias de duração em UZ.

\section{A necessidade de irrigação foi determinada} pela pesagem individual dos vasos e complementação do peso. com àgua duas vezes ao dia.

\subsection{Determinações}

3.9.1. Taxa de expansão foliar

o perfilho principal (haste principal) de cada planta (dois em cada vaso) foi identificado com anéis plästicos coloridos, sendo as medições de expansão foliar feitas nesta haste durante o transcorrer do experimento. 
A taxa de expansão ou elongação foliar (THOMAS, 1980) foi verificada medindo-se uma vez ao dia, entre 7 e 9 horas da manhã do dia 0 ao 28 o de imposição dos trata mentos; o comprimento da folha (lâmina mais bainha). Esta medição era feita com uma régua colocada contra a base da haste principal, usando a superficie do solo como ponto de referència.

Tanto a folha mais nova como a segunda folha mais nova da haste principal foram medidas. Assim que a próxima folha (por exemplo, folha 10) emergia, a folha 9 tor nava-se a segunda folha mais nova e as medições na folha 8 cessavam.

Uma folha era considerada emergida quando podia ser inicialmente vista projetando-se da bainha foliar precedente.

3.9.2. Taxa de emergência foliar

Diariamente, durante 29 dias (do dia 0 ao 28 ? de imposição dos regimes de umidade), foi verificado o número de folhas (a ültima folha emergida) na haste principal de cada planta (THOMAS, 1980). Utilizaram-se as mesmas hastes usadas para a avaliação da taxa de expansão foliar. 
3.9.3. Número de folhas por planta, número de folhas por perfilho e número de perfilhos por planta.

Aos $0,7,14,21$ e 28 dias de imposição dos rẹ gimes de umidade: feita a contagem do númerode folhas por planta, por perfilho e o número de perfilhos por planta. Para a contagem do número de folhas não eram consideradas as folhas com mais de $50 \%$ (estimativa visual) de tecido não verde (clorótico e/ou necrosado).

\subsubsection{Produção de matéria seca da parte aérea}

Aos 7, $1.4,21$ e 28 dias após imposição dos re regimes de umidade, três vasos por tratamento (três repetições por tratamentol tinham as plantas cortadas rente ao solo, sendo a parte aérea imediatamente pesada para determinação da matéria verde. Após a pesagem o material era cortado em pedaços pequenos e colocado em bandejas individuais para facilitar a secagem, permanecendo por aproximadamente 48 horas em estufa com circulação de ar forçada a temperatura de $60-70^{\circ} \mathrm{C}$, sendo posteriormente pesado para determinação do peso seco.

Para esta variável foi considerada a somató ria das duas plantas por repetição (vaso). 
3.9.5. Produção de matéria orgânica da raiz

Após o corte da parte aerea para determina ção da matéria seca, o volume total do solo era retirado do vaso e lavado cuidadosamente sobre uma peneira de malha de $2 \mathrm{~mm}$ com àgua corrente para recuperar as raizes.

Após recuperadas, as raízes eram então mantidas por aproximadamente 48 horas à temperatura de $60-70^{\circ} \mathrm{C}$ em estufa com circulação de ar forçada.

$$
\text { Após a secagem as raízes eram pesadas e moídas, }
$$
sendo retiradas duas subamostras por repetição para determinação da matéria orgânica através da queima em mufla a $500^{\circ} \mathrm{C}$ por 4 horas.

o valor obtido refere-se a somatória das duas plantas por repetição.

3.9.6. Relação raiz:parte aērea

Esta variável foi calculada através da razão entre a matéria orgânica da raiz e a matéria seca da parte aèrea.

3.9.7. Composição mineral da parte aérea

Após a pesagem para determinação do peso seco a parte aérea era moída em moínho de aço inoxidável e 
acondicionada em sacos plásticos cuidadosamente fechados pạ ra posterior determinação da composição mineral.

Para a determinação da concentração (\% na mạ téria seca) de P, K, Ca, Mg e S na parte aérea foi empregado o método de digestão nitroperclörica com bloco digestor e espectrofotometria de absorção atômica (ZAGATTo et alii, 1981; SALINAS e GARCIA, 1985). A quantidade absorvida pela planta ou conteúdo absoluto (mg do mineral na parte aérea) foi determinada através do produto da produção de matéria seca da parte aérea pela concentração do mineral correspondente.

\subsubsection{Eficiência do uso de nutriente}

A eficiência do uso de nutriente ( $P$ e $K$ ) foi determinada conforme MISRA e SINGH (1982), através da relação entre matéria seca produzida por unidade de $P$ ou K absorvido.

\subsection{Anālise estatistica}

0s dados referentes a cada variável resposta foram submetidos à anălise de variância, procedendo-se os seguintes desdobramentos:

Teste de Tukey para médias de cada regime de umidade;

Teste de Tukey para médias de regimes de umidade dentro dos niveis de epocas; 
Teste de Tukey para mëdias de ëpoca dentro de cada regime de umidade, e

Regressão polinomial considerando o fator época para cada regime de umidade.

Os quadros de anālise de variância são apre sentados nas tabelas 10 a 18 no apêndice deste trabalho. 


\section{RESULTADOS E DISCUSSÃO}

\subsection{Taxa de expansao foliar}

A taxa de expansão foliar mostrou ser muito influenciada pela umidade do solo, principalmente nos pe riodos iniciais de avaliação do ensaio (Figura 2 e Tabela 2). Assim é que jà no primeiro dia após a imposição dos tratamentos a taxa média de expansão foliar apresentada pela U1 $(9,0 \mathrm{~cm} / \mathrm{dia})$ já apresentava uma superioridade significativa $(P<0,05)$ em relação às taxas encontradas pạ ra U2 $(6,4 \mathrm{~cm} / \mathrm{dia})$ eU3 $(6,6 \mathrm{~cm} / \mathrm{dia})$.CHU et alii (1979) encontraram em Bromus catharticus submetido a estresse hidrico uma queda na taxa de elongação foliar três dias após a imposição dos tratamentos. Naquela situação as condições contro ladas de temperatura e umidade do ar, entre outros fatores, podem ter contribuido para que $B$. catharticus apresentasse esta resposta mais tardia à condição de umidade do solo.

No presente estudo as condições de estresse 


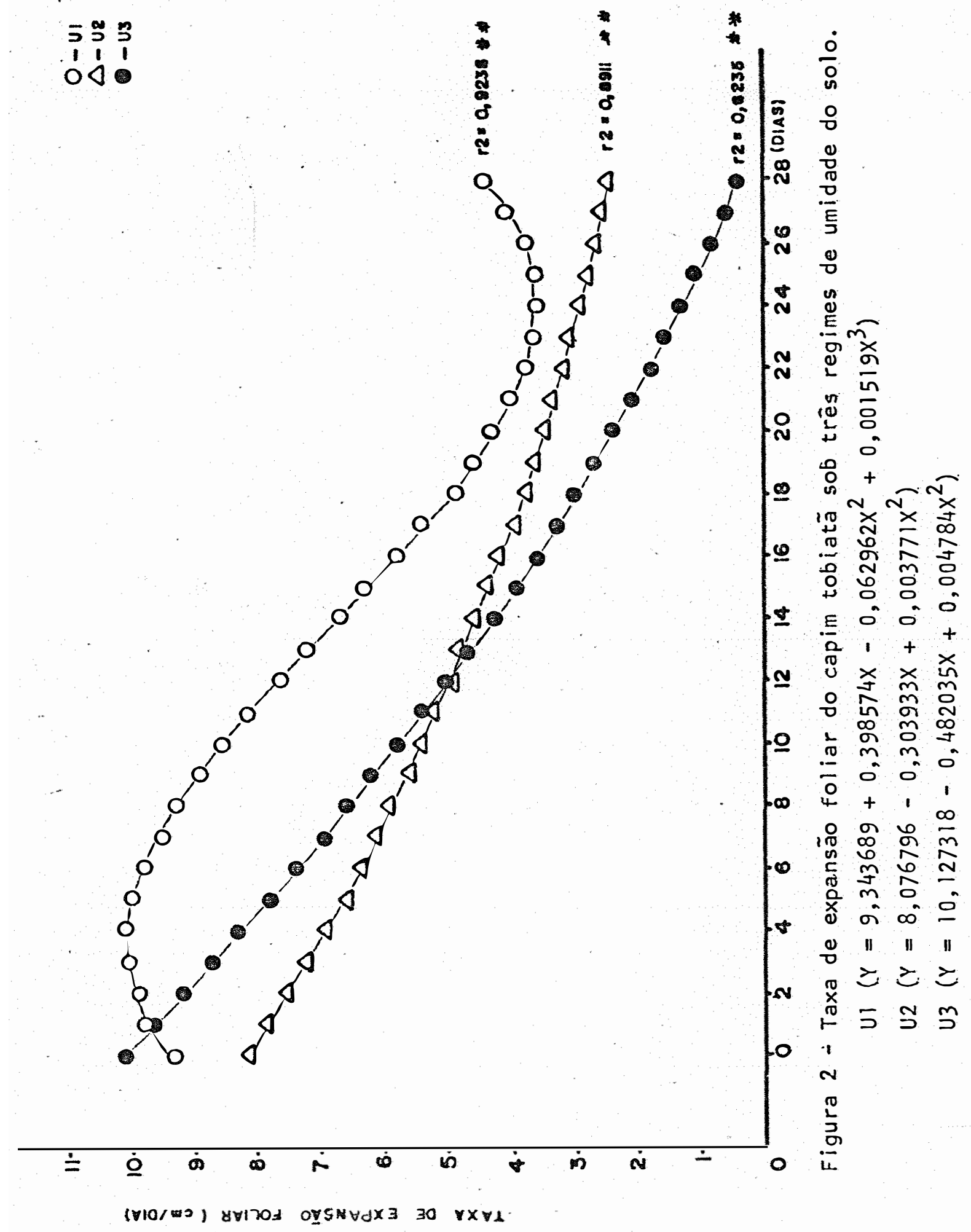


Tabela 2 - Expansão ${ }^{(a)}$ foliar mëdia (cm/dia) de capim tobiatã (Panicum maximum cv. Tobiatã) submetido a regimes de umidade do solo (valores relativos entre re gimes de umidade para o mesmo dia são apresenta dos em parêntesis).

\begin{tabular}{|c|c|c|c|}
\hline \multirow{2}{*}{ Dias } & \multicolumn{3}{|c|}{ Regimes de Umidade } \\
\hline & U1 & $\mathrm{U} 2$ & U3 \\
\hline 0 & $9,7 a(100)$ & $9,6 a \quad(99)$ & $9,7 a(100)$ \\
\hline 1 & $9,0 a \quad(100)$ & $6,4 b(71)$ & $6,6 b(73)$ \\
\hline 2 & $11,3 a \quad(100)$ & $7,16(63)$ & $8,7 b(77)$ \\
\hline 3 & $9,8 a \quad(100)$ & $6,5 b \quad(66)$ & $9,5 a(97)$ \\
\hline 4 & $9,3 a \quad(100)$ & $7,4 b(80)$ & $9,4 a(101)$ \\
\hline 5 & $9,5 a \quad(100)$ & $5,2 b(55)$ & $9,6 a(101)$ \\
\hline 6 & $9,8 a \quad(100)$ & $7,6 b \quad(78)$ & $9,2 a b(94)$ \\
\hline$i$ & $8,4 a(100)$ & $6,2 b(84)$ & $6,7 a b(80)$ \\
\hline 8 & $10,1 a(100)$ & $6,7 b \quad(66)$ & $7,4 b(73)$ \\
\hline 9 & $8,7 a(100)$ & $5,7 b(66)$ & $6,2 b(71)$ \\
\hline 10 & $9,8 a \quad(100)$ & $6,1 b \quad(62)$ & $5,7 b(58)$ \\
\hline 11 & $8,5 a \quad(100)$ & $4,5 b(53)$ & $5,4 b(63)$ \\
\hline 12 & $7,1 \mathrm{a}(100)$ & $4,7 b(66)$ & $4,7 b(66)$ \\
\hline 13 & $7,2 a \quad(100)$ & $4,6 b \quad(64)$ & $4,9 b(68)$ \\
\hline 14 & $5,7 a(100)$ & $4,9 a(86)$ & $5,5 a(96)$ \\
\hline 15 & $7,1 a(100)$ & $4,8 b(68)$ & $4,9 b \quad(69)$ \\
\hline 16 & $6,5 a(100)$ & $3,9 b(60)$ & $1,5 c(23)$ \\
\hline 17 & $5,9 a \quad(100)$ & $4,6 a(78)$ & $2,3 b(39)$ \\
\hline 18 & 5,1 a $(100)$ & $3,7 a b(73)$ & $2,7 b(53)$ \\
\hline 19 & $4,4 a(100)$ & $4,6 a(105)$ & $1,7 b(39)$ \\
\hline 20 & 4 , ia $(100)$ & $3,8 a b(93)$ & $2,2 b(54)$ \\
\hline 21 & $3,4 a(100)$ & $3,4 a(100)$ & $1,9 a(56)$ \\
\hline 22 & $4,1 a(100)$ & $2,4 a b(59)$ & $1,9 b(46)$ \\
\hline 23 & $2,8 a \quad(100)$ & $1,8 a(64)$ & $1,2 a(43)$ \\
\hline 24 & $3,0 a(100)$ & $2,2 \mathrm{ab}(73)$ & $0,6 b(20)$ \\
\hline 25 & $3,9 a \quad(100)$ & $2,4 a b(62)$ & $1,0 b(26)$ \\
\hline 26 & $5,3 a(100)$ & $2,7 b \quad(51)$ & $0,9 c(17)$ \\
\hline 27 & $3,7 a(100)$ & $2,5 a b(67)$ & $1,4 b(38)$ \\
\hline 28 & $4,5 a \quad(100)$ & $4,1 a(91)$ & $1,5 b(33)$ \\
\hline
\end{tabular}


hidrico foram quase sempre intensificadas pelas altas temperaturas e baixa umidade do ar que foram observadas no decorrer do ensaio (dados não apresentados). obviamente, o vi gor de crescimento da gramínea utilizada também contribuiu para estes resultados.

Observa-se na Tabela 2 e Figura 2 que, com o decorrer do tempo, as taxas de expansão foliar apresentadas pelas plantas em Ul, principalmente, e U2 apresentaram uma queda que pode ser interpretada como um efeito aditivo de värios fatores. 0 esgotamento progressivo de alguns dos nutrientes do solo pode ter sido principalmente para as plantas em Ul, limitante para a manutenção de um rítmo regular de crescimento. Por outro lado, é sabido que a restrição de volume de solo disponivel para o desenvolvimento da zona radicular e crescimento da raiz pode causar sintomas de estresse hidrico em plantas, mesmo não estando a ăgua limitante na zona radicular (KRIZEK et alki, 1985). No estudo de KRIZEK et alii (1985) foi encontrada redução da expansao foliar em so ja (Glycine $\max$ (L.) Merr.) cultivada em condições que restringiram o volume da zona radicular. E possivel inferir, portanto, que principalmente para as plantas de Ul, devido a maior massa radicular (Tabela 5), este efeito tenha sido intensificado com o decorrer do tempo. Finalmente, outro fạ tor que pode ter tido influência foi o nível de inserção das folhas. Trabalho desenvolvido por WILSON (1976) com Panicum maximum var. trichoglume mostrou que folhas no mes- 
mo estádio de desenvolvimento apresentaram, entre outras caracteristicas, um crescimento mais lento à medida que o nível de inserção aumentava. De fato, examinando-se a Figura 3 é possível ser observado que as plantas em Ul apresentaram um desenvolvimento ontogênico mais acelerado que os outros tratamentos.

A redução na taxa de expansāo. foliar observada com o decorrer do tempo em U3 era esperada podendo ser atribuida principalmente a progressiva condição de estresse hidrico experimentada pelas plantas submetidas a este tratamento. As tendências marcantes quanto a reduções na taxa de expansão foliar encontradas em U3 a partir do 16 ? dia (Tabela 2), mesmo sob umidade do solo ( $29 \%$ de água) idêntica a U2, pode significar que, ao contrário de U2, onde as plantas apresentaram valores de decréscimos na taxa de expansão foliar de certa forma uniformes ao longo das avaliações, estas plantas, possivelmente, 'não se encontra-. vamadaptadas a esta nova condição de umidade do solo. De fạ to, segundo MORGAN (1984), existem evidências que plantas previamente expostas a estresse hidrico mostram maior capacidade em tolerar periodos subsequentes de estresse hidrico, através de aumentos nos níveis de soluto celular, suposição que pode ser de certa forma reforçada examinando-se a Figura 8. NG et alii (1975) encontraram também este tipo de resposta de adaptação em plantas de $P$. maximum var. trichoglume que haviam sido submetidas a maior número de ciclos de estresse hidrico. 
No presente experimento, observações visuais mostraram que, mesmo em situações em que a quantidade de àgua no solo era idêntica, as plantas em U3 apresentavam mur chamento nos periodos mais quentes do dia, enquanto que em U2 as plantas permaneciam visualmente inabaladas.

Examinando-se esta questão de maneira mais ampla é possivel ainda inferir-se que as plantas em U3, ao contrário das plantas em U2, teriam que desenvolver maior esforço metabólico visando a manutenção da biomassa acumulada as custas de melhor condição anterior de umidade, o que foi traduzido em economia de gasto energético através da brusca redução no crescimento destas plantas.

Esta observação pode ter uma grande importância prática já que, pelas evidências apresentadas, seria razoável admitir que plantas desenvolvendo-se com menor disponibilidade de àgua no solo terão, possivelmente, melhor capa cidade de desenvolvimento em condições de estresse hídrico do que aquelas que iniciaram o crescimento nas condições favoráveis de umidade do solo.

\subsection{Taxa de emergência foliar}

Esta variável mostrou-se dependente dos regimes hidricos a que foram submetidas as plantas, sendo maior nas situações de estresse (Figura 3). Assim é que a taxa 


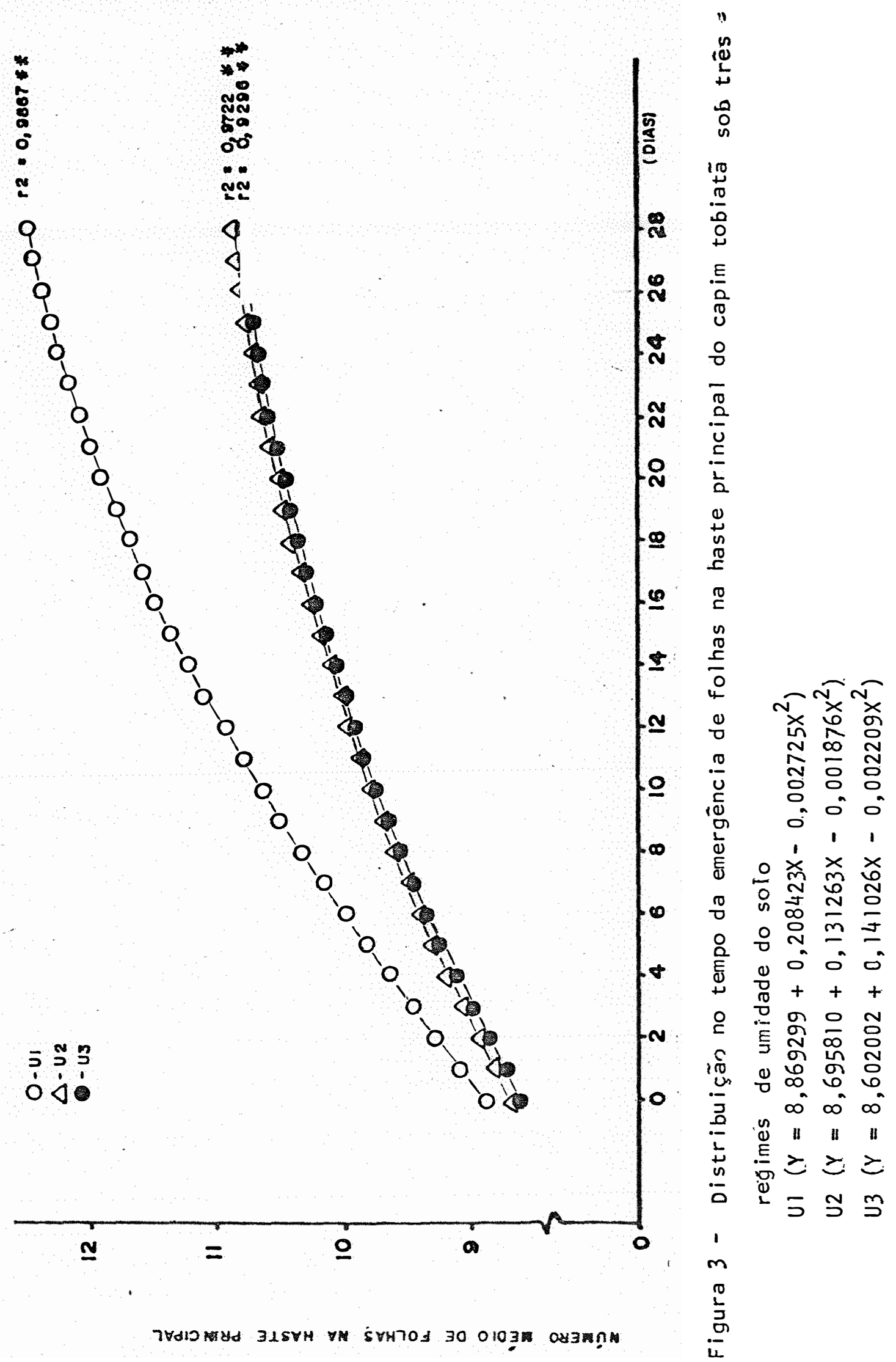


de aparecimento foliar, para a capacidade de campo (UI), entre as folhas 9 e 12 foi de certa forma constante, apresentando um valor médio de 5,61 $\pm 0,15$ dias entre folhas. Para as plantas submetidas a U2 a taxa de aparecimento foi de $8,97 \pm 1,77$, para o mesmo intervalo de folhas. Já para - tratamento estresse hídrico progressivo esta variável, co mo poderia ser esperado, foi muito menos constante, apresentando valor médio de $9,19 \pm 3,63$ dias entre folhas, sendo minimo $(6,57 \pm 2,99)$ entre as folhas 9 e 10 e máximo $(13,33 \pm 1,88)$ entre a 11 ? e $12^{\text {a }}$. folhas. Estes valores ind cam que o desenvolvimento ontogênico em Ul foi mais acelera do que em U2 e U3.

Não obstante a diferença no desenvolvimento ontogênico entre tratamentos, no 28 : dia de avaliação, o nú mero (ültima folha produzida) mëdio de folhas na haste prin cipal não apresentou diferença significativa $(P>0,05)$ entre os três tratamentos, sendo, respectivamente, para Ul, U2 e U3, 12,7, 10,8 e 10,8. Embora numericamente esta diferença ( 2 folhas) não. seja significativa, deve ser salientado que as plantas em $U 2$ necessitariam em torno de 18 dias $(8,97 \times 2)$ para atingir o desenvolvimento fisiológico que apresentavam as plantas em Ul, se for considerado que esta taxa permanecesse constante. De fato, segundo SILSBURY (1970) a taxa de aparecimento foliar para muitas gramineas forrageiras, cultivadas em ambiente controlado, parece ser constante com o tempo. Devido as caracteristicas do tratamento, 
em U3 esta diferença representaria maior amplitude de variação.

0s valores identicos encontrados para U2 e U3 devem-se principalmente ao maior intervalo entre as folhas 9 e 10 e o menor intervalo entre a 11 a e 12 a folhas apresentado pelas plantas do tratamento U2 em relação a U3 (dados não apresentados). Esta característica configura de forma mar cante o estresse hidrico progressivo sofrido pelas plantasem U3.

o desenvolvimento mais lento ou atraso ontogê nico das plantas submetidas aos tratamentos de estresse hidrico poderia ser encarado como uma vantagem quando se observa dados da literatura que mostram aumento no conteūdo de parede celular e diminuição na digestibilidade da matéria seca da lâmina foliar com o aumento do nível de inserção des tas folhas em P. maximum var. trichoglume (WILSON, 1976). Es ta caracteristica aliada ao fato do estresse hidrico poder suspender ou diminuir o processo normal de envelhecimento das folhas (WILSON, 1983), poderia inclusive parcialmente compensar outros efeitos negativos causados pelo estresse hí drico.

\subsection{Nümero de follhas}

o nūmero médio de folhas por planta (Figura 4 


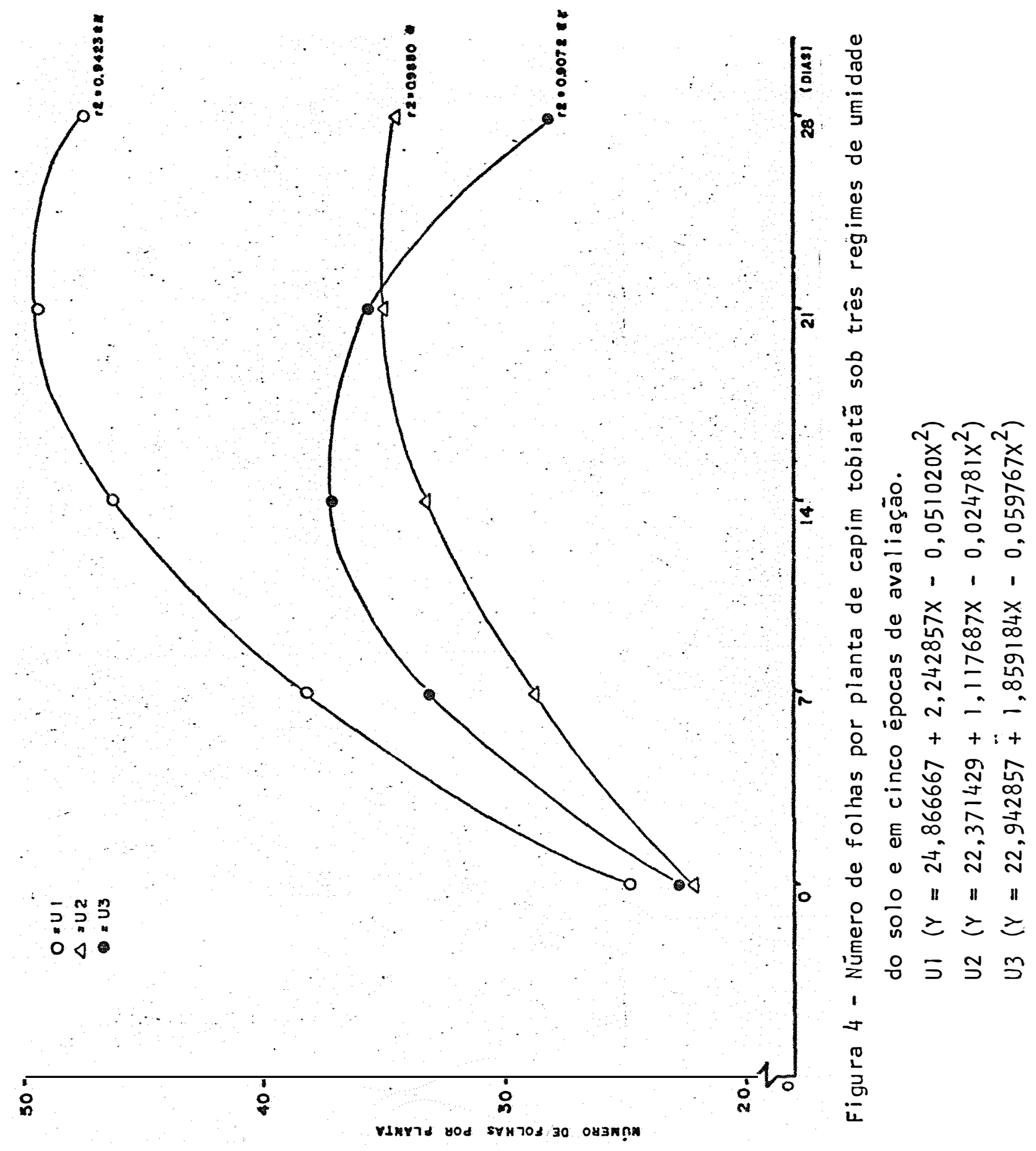


e Tabela 3 ), foi negativamente influenciado pelo estresse hí drico, enquanto que o nümero mëdio de follhas por perfilho (Tabela 4) sofreu apenas efeito de U3.

Até a avaliação correspondente ao 14! dia de imposição dos tratamentos houve um crescimento positivo no nümero de folhas por planta e por perfilho. As plantas submetidas a U3 (Figura 4 e Tabelas 3 e 4 ) mostraram jáa partir da segunda semana de avaliação efeito negativo do estres se hidrico indicando morte das folhas mais velhas (dados não apresentados), condị̧ão que, de acordo com KRAMER (1983), po deria expressar o efeito de competição por água das folhas mais novas sobre as mais velhas. NG et alii (1975) observa ram em $P$. maximum var. trichoglume submetido a estresse hidrico um aumento na taxa de morte das folhas mais velhas.

Em Ul ocorreu aumento no nümero de folhas por perfilho até 021 o dia enquanto U2 este incremento foi verificado até o 14: dia. Com relação ao nümero de follhas por planta este aumento em UI foi significativo $(P<0,05)$ entre os dias 0 e 7 de avaliação, não tendo sido significativo para as demais épocas entre si (Tabela $3^{\circ}$ ). Em U2 só a partir do 149 dia o aumento do número de folhas por planta foi significativo (Tabela 3 ), omportamento semelhante foi observado para nümero de folhas por perfilho (Tabela 4 ).

Somente entre o $210^{\circ}$ e $280^{\circ}$ dia pôde ser detectada uma tendência de estabilização em U2 e em Ul no nūmero 
Tabela 3 - Nümero médio(a) de folhas por planta em ëpocas distintas (b) em capim tobiatã (Panicum maximum cv. Tobiatã) submetido a très regimes de umidade do solo (valores relativos entre regimes de umidade são apresentados em parêntesis).

\begin{tabular}{|c|c|c|c|c|c|}
\hline \multirow{2}{*}{$\begin{array}{l}\text { Regime de } \\
\text { Umidade }\end{array}$} & \multicolumn{5}{|c|}{ Epocas $^{(b)}$} \\
\hline & 0 & 7 & 14 & 21 & 28 \\
\hline \multicolumn{6}{|c|}{ Capacidade } \\
\hline de campo & $23,3 a B$ & $42,0 \mathrm{aA}$ & $43,7 \mathrm{aA}$ & $49,0 \mathrm{aA}$ & $48,3 a A$ \\
\hline UI & $(100)$ & $(100)$ & $(100)$ & $(100)$ & $(100)$ \\
\hline \multicolumn{6}{|l|}{ Estresse } \\
\hline \multicolumn{6}{|c|}{ hidrico } \\
\hline \multicolumn{6}{|c|}{ constante } \\
\hline U2 & $(94,3)$ & $(70,6)$ & $(76,3)$ & $(69,4)$ & $(77,7)$ \\
\hline \multicolumn{6}{|l|}{ Estresse } \\
\hline \multirow{2}{*}{\multicolumn{6}{|c|}{$\begin{array}{l}\text { hídrico } 22,3 a C \\
\text { progressivo }\end{array}$}} \\
\hline & & & & & \\
\hline U3 & $(95,7)$ & $(80)$ & (89) & $(66,7)$ & $(60,7)$ \\
\hline
\end{tabular}

(a)

Valores seguidos da mesma letra minüscula nas colunas não têm diferença significativa $(P \leqslant 0,05)$. Valores seguidos da mesma letra maiüscula nas linhas não tem diferença significativa $(P \leqslant 0,05)$.

(b) Dias após imposição dos tratamentos. 


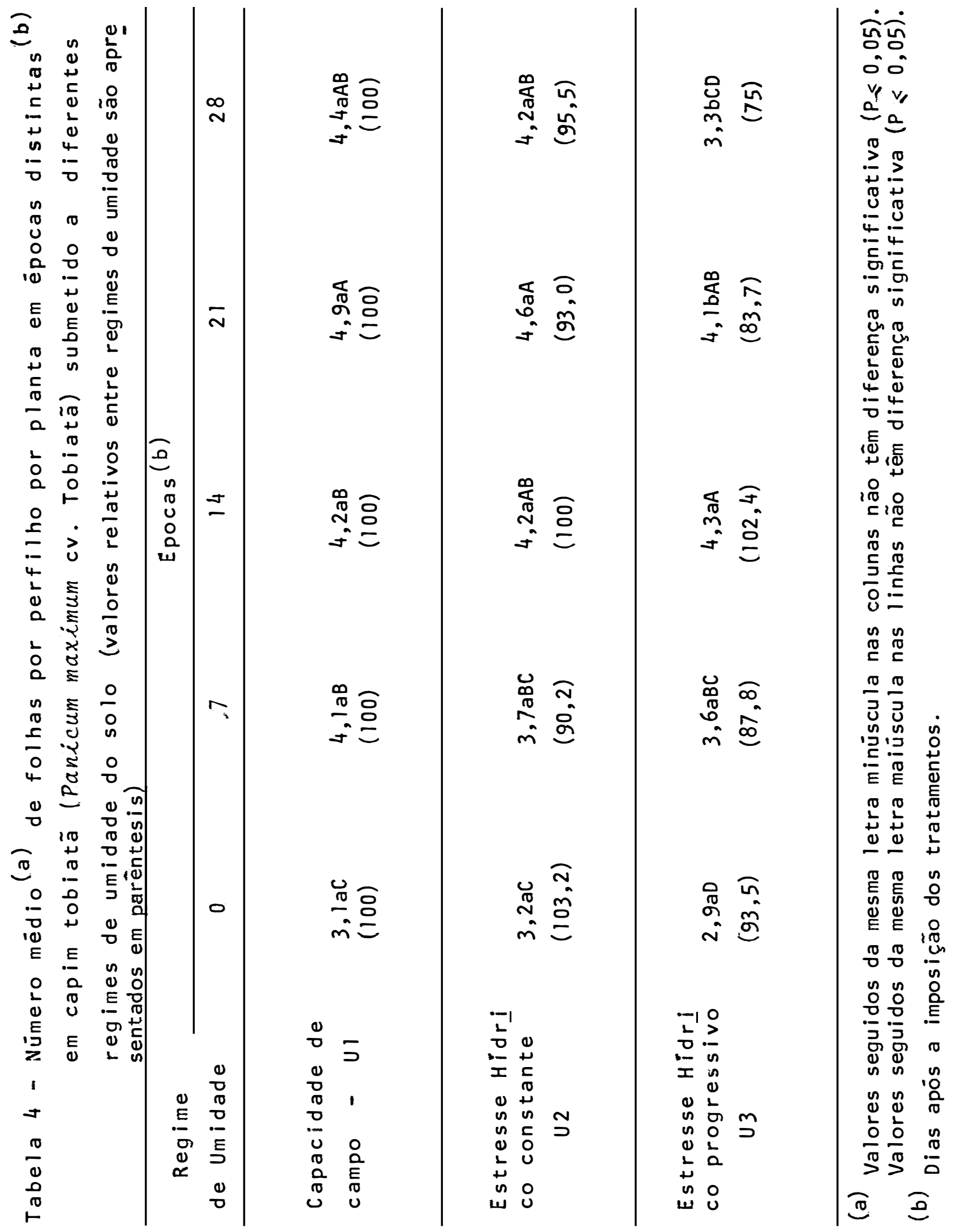


de folhas por perfilho e por planta (Figura 4 e Tabela 4 ). Este efeito, particularmente em Ul, deveu-se possivelmente ao esgotamento de nutrientes do solo em função do rítmo acelerado de crescimento da planta, podendo ainda ter estado associado a fatores como auto-sombreamento, ontogenia da planta e a intensificação da competição por assimilados na planta. E possivel ainda supor que, conforme observaram KRIZEK et alii (1985) em soja, pode ainda ter havido um efeito adicional da restrição do volume do solo disponível para o desenvolvimento das raizes, o que causaria um efe to semelhante ao provocado pelo estresse hidrico, onde a taxa do aparecimento de folhas não consegue compensar a morte destas. Pode-se assim supor que as plantas que se de senvolveram sem restrição de àgua atingiram a estabiliza ção e possivelmente decréscimo no número de folhas mais rapidamente do que as plantas em $U 2$.

\subsection{Nümero de perfilhos por planta}

o numero médio de perfilhos por planta foi significativamente $(P<0,05)$ diminuido pelo estresse hidrico (Tabela 5). Porém, para a ültima época de avaliação (28: dia de imposição dos tratamentos) os valores relativos para U2 e U3 foram somente em torno de 20 a $25 \%$ inferiores ao valor alcançado por Ul no mesmo período (Tabela 5). De maneira semelhante NG et alii (1975), estudando o 


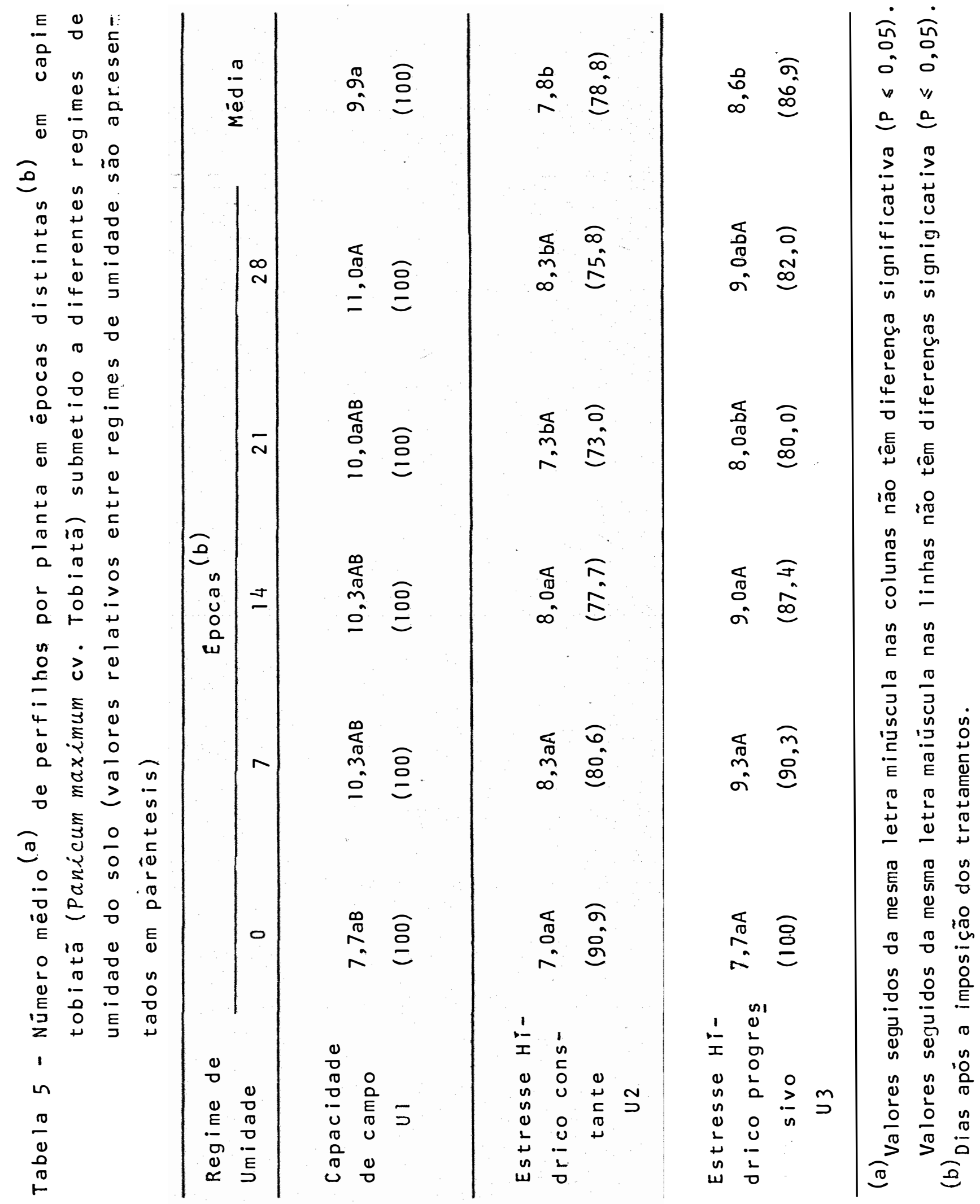


efeito de estresse hidrico em $P$. maximum var. trichoglume, em vasos, encontraram que o nümero de perfilhos não mostrou-se muito afetado pelo estresse hidrico, tendo sido alcançado valor máximo de número de perfilhos, no tratamen to com estresse hidrico $14 \%$ inferior ao tratamento testemu nha.

Para os très tratamentos, pode ser inferido que o número de perfilhos por planta foi estabelecido praticamente na primeira semana de avaliação deste ensaio (.79. dia), não se alterando com o tempo, resultando em uma diferença não significativa $(P>0,05)$ entre esta $e$ as demais épocas de avaliação dentro de um mesmo tratamento. Esta tendência confirma as observações de CoRsI (1984) so bre outra variedade de $P$. maximum que, no periodo in icial de avaliação, já apresentava o número final de perfilhos. Já CHU et alii (1979) observaram em Bromus catharticus que, durante o periodo de estresse hidrico, o número de perfilhos por planta, embora de maneira lenta, apresentou incre mento, não obstante tenha sido reportado que as plantas não submetidas a estresse hidrico tenham alcançado maior nümero de perfilhos por planta.

E possivel que no presentre trabalho o manejo de fertilização empregado, com apenas uma fertilização inicial, tenha limitado o desenvolvimento da planta principalmente em fun ção de uma possivelrestrição de nutrientes, notadamente ni- 
trogênio no solo, o que refletiu em limitação no potencial de perfilhamento da gramínea, em particular as submeti das ao tratamento UI.

\subsection{Produção de matēria seca da parte aérea}

$$
0 \text { peso seco da parte aérea mostrou uma }
$$

grande redução com o decréscimo no conteūdo de umidade do solo (Tabela 6). Jáa partir da primeira época de avaliação, sete dias apōs a imposição dos tratamentos, a produção de matēria seca da parte aérea das plantas submetidas a Ul era a significativamente $(P<0,05)$ superior a U2 e U3, que apresentavam produções relativas de, respectivamente, 57,6 e $68,5 \%$ da al cançada por U1.

0 comportamento produtivo de U3 no 7? diá mostra que, em solos com capacidade de retenção de ägua semelhante ao utilizado neste experimento, pequenas quedas no conteūdo de água do solo podem ter, em curtos espaços de tempo, um efeito significativo na diminuição da produção de matéria seca.da planta, mesmo sob condições satisfatōrias de fertilidade do solo. E evidente, no entanto, que plantas cultivadas em vasos sofrem de maneira mais intensa e brusca os efeitos do estresse hídrico, já que praticamente todo o sistema radicular experimenta, de maneira uniforme a mesma situação de umidade do solo (BEGG e TURNER, 1976), não havendo condição para adaptação da planta. 


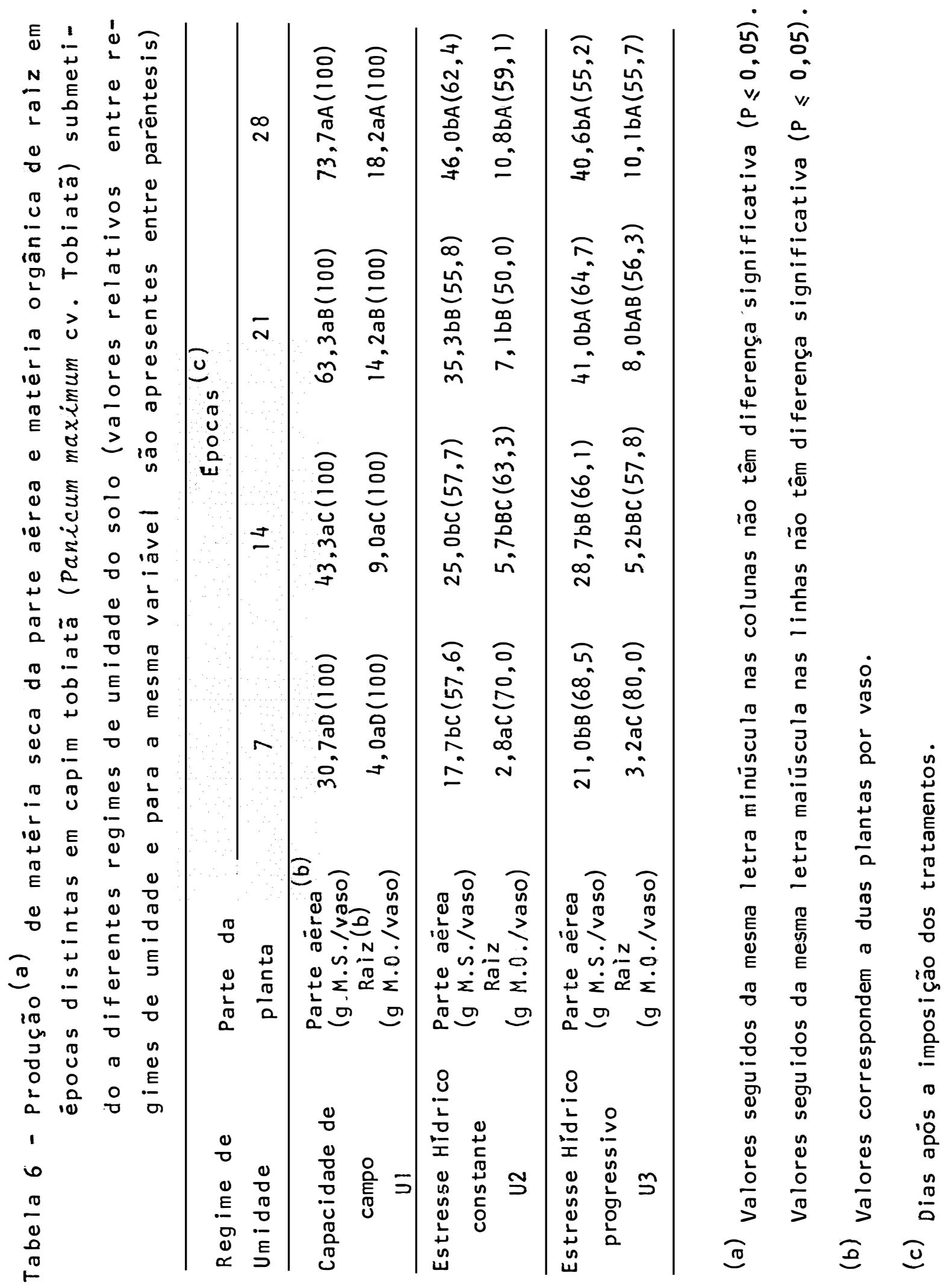


Nas avaliações subsequentes as produções de matéria seca em Ul foram sempre significativamente superiores $(P<0,05)$ aos demais tratamentos (Tabela 6). As plantas submetidas ao estresse hidrico progressivo (U3) não apresentaram, na ūltima época de avaliação (28\% dia de imposição dos tratamentos) aumento na produção de matéria seca, tendo inclusive havido uma tendência, não sig nificativa de decréscimo de produção entre a penúltima e ültima épocas de avaliação. Esse comportamentodeveu-se pro vavelmente ao reflexo na queda da área fotossintética da planta devido a tendência de decréscimo no número (Tábela 3. e Figura 2) e elongação de folhas (Tabela 2) neste tra tamento, causado pela condição de estresse $(27 \%$ de àgua no solo) experimentada na última semana de avaliação do ensaio. De fato, o aspecto visual destas plantas em termos de vigor durante este periodo era bem inferior ao das plantas do tratamento U2 (dados não apresentados).

Não hã diferença entre U2 e U3, mas observa se na Tabela 6 que o incremento de produção ao longo do tem po. não é o mesmo entre os dois regimes de umidade. As di ferenças de produção em U3, ao conträrio de U2, só ocorrem apös cada 14 dias.

\subsection{Produção de matēria orgânica da raiz}

A produção de matéria orgânica da raiz mos- 
trou comportamento semelhante a produção de matéria seca da parte aérea (Tabela 6). Porém, pode ser visto que, até a segunda avaliação, a redução relativa no crescimento das raizes proporcionada pelo estresse hidrico foi menor. do que a encontrada na parte aérea, confirmando resultados de TURNER e BEGG (1981). Esses autores sugerem que o cresci mento da raiz sob estresse hidrico é geralmente favorec do em relação ao crescimento da parte aérea. Pode-se obser var, no entanto, que em termos relativos o sistema radicular das plantas sob estresse hidrico (U2 e U3) foi reduzido com maior intensidade do que a parte aérea à medida que os tratamentos eram avaliados. Assill, aos 21 dias, o siste ma radicular para U2 e U3 foi reduzido para 50,0 e $56,3 \%$, respectivamente, em relação a Ul, enquanto que a parte áérea foi decrescida ao nivel de 55,8 e $64,7 \%$, respectivamen te, para U2 e U3. Resultado semelhante que demonstra ser o sistema radicular é mais reduzido em termos relativos do que a parte aérea sob estresse hídrico foi descrito por GALES (1979).

No presente trabalho o fato do material morto das raizes não ser descartado, sendo portanto considerado para os cálculos de produção, pode, notadamen te nas últimas duas épocas de avaliação, ter tido alguma influência na amplitude dos resultados obtidos. De qualquer maneira, esta variável retrata a produção total de raizes durante um determinado período e não a quantidade 
de raizes fisiologicamente ativas em uma determinada fase de crescimento da planta.

\subsection{Relaçāo raiz:parte aérea}

A relação raiz:parte aérea, para todas as égocas avaliadas, não foi significativamente $(P>0,05)$ influenciada pelo estresse hídrico (dados não apresentados). Pode ser observado na Figura 5 que, nas avaliações iniciais, correspondentes ao sétimo e 14 ? dia apos a imposição dos tratamentos, o estresse hídrico provocou em U2 uma tendência de aumento na relação raiz:parte aérea em relação aos tratamentos Ul e U3; por outro lado, nas avaliações subse quentes ( $21 \%$ e 28 \% dias), esta tendência inverteu-se. GALES (1979) encontrou em L. perenne, submetido a estresse hídrico, a mesma dinâmica de resposta. Esta tendência de superioridade na relação raíz:parte aérea das plantas não submetidas a estresse hídrico pode ser vista como consequência de uma possível deficiência nutricional, notadamente de $P, \quad j a ́$ que é sabido que o aumento da relação raíz:parte aérea pode ser uma resposta típica à deficiência de P no solo ou a ba i xa concentração deste nutriente na planta (GALES, 1979;

OZZANE, 1980). De fato, as plantas em Ul realmente experi mentaram uma queda na concentração de $P$ na matēria seca que acentuou-se na avaliação feita aos 21 dias de imposição dos tratamentos. 


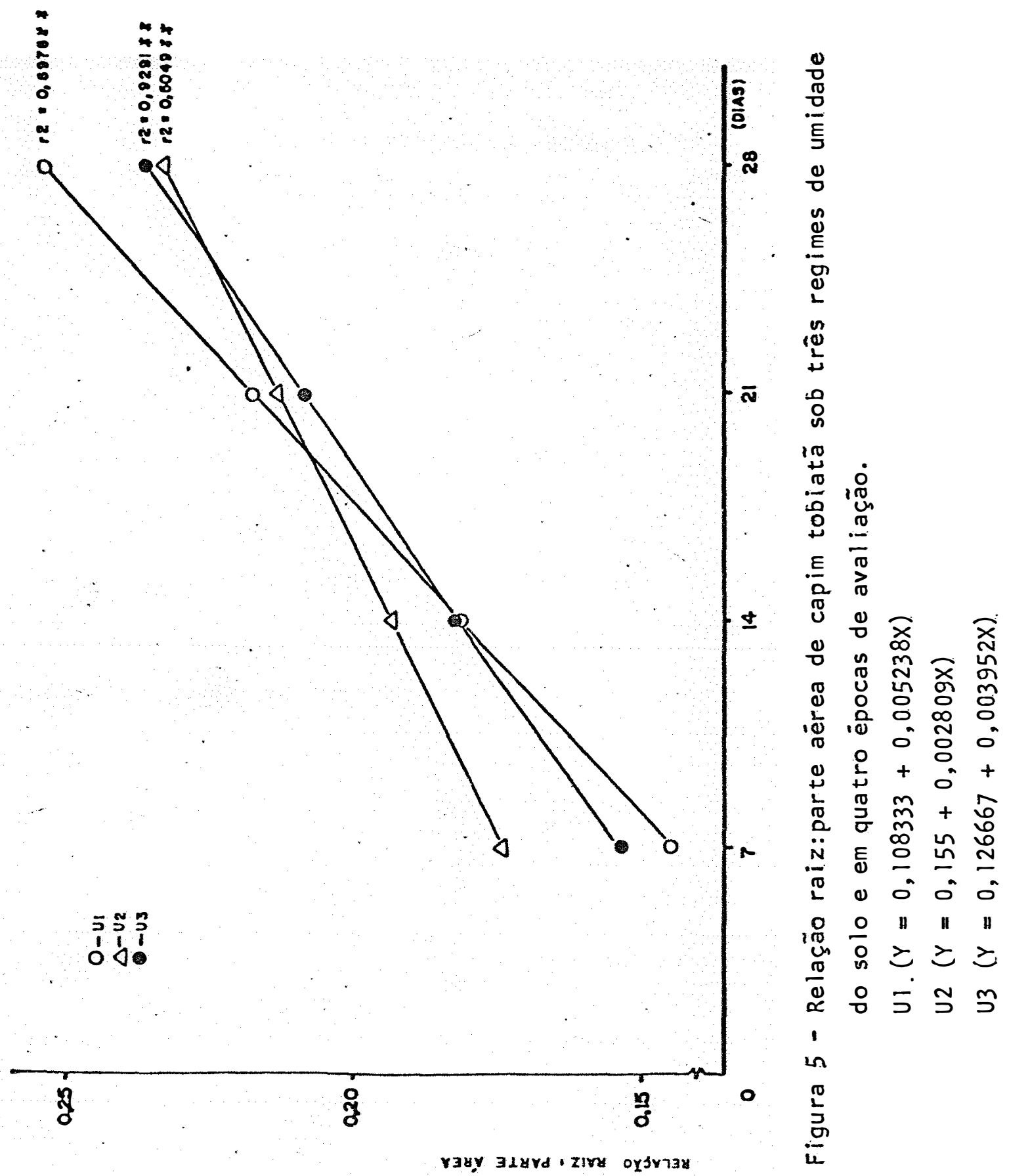




\subsection{Composiçäo mineral}

os resultados mostraram, de modo geral, ten dência de aumento ou estabilização na concentração de minerais na matéria seca devido ao estresse hídrico (Tabela 7).. No entanto, quando a composição mineral foi expressa de forma absoluta (mg/vaso) houve um decréscimo na absorção total com o estresse de umidade (Tabela 8).

\section{As concentrações dos nutrientes mostraram}

geralmente decréscimo com a idade da planta, o que pode ser entendido como efeito da diluição causada pela relatí vamente maior produção de matéria seca (MISRA e SINGH, 1982) e queda de niveis de nutrientes no solo, particularmente para o tratamento Ul.

\subsubsection{Fösforo}

Houve influência do estresse hidrico na con centração de $P$, como pode ser observado a partir da segun da época de avaliação para U3 e após 21 dias para U2 (Tabela 7 e Figura 6). Este comportamento difere daquele en contrado na literatura (MISRA e SINGH, 1982; KRIZEK et alii, 1985), onde o estresse de umidade do solo geralmente favorece o menor acúmulo de fósforo no tecido da planta estressada. A menor concentração de fósforo no trata mento Ul pode ser explicada pelo efeito de diluição deste mineral no tecido vegetal devido ao mais rápido aumento na 
Tabela 7 - Concentração $^{(a)}$ de minerais (\% na matēria seca) em épocas distintas (b) em capim tobiatã (Panicum maximum cv. Tobiatã) submetido a diferentes regimes de umidade do solo

\begin{tabular}{|c|c|c|c|c|c|}
\hline \multirow{2}{*}{ MINERAL } & \multirow{2}{*}{$\begin{array}{l}\text { Regime de } \\
\text { Umidade }\end{array}$} & \multicolumn{4}{|c|}{ Epocas $^{(b)}$} \\
\hline & & 7 & 14 & 21 & 28 \\
\hline & U: & $0,23 a A$ & $0,14 \mathrm{bB}$ & $0,10 \mathrm{bc}$ & $0,11 a c$ \\
\hline \multirow[t]{3}{*}{ Fösforo } & U2 & $0,20 a A$ & $0,15 a b B$ & $0,13 a B C$ & $0,11 a c$ \\
\hline & U3 & $0,22 \mathrm{aA}$ & $0,17 a B$ & $0,12 a b c$ & $0,12 a c$ \\
\hline & IU & $2,32 \mathrm{bA}$ & $1,33 \mathrm{bB}$ & $0,74 b c$ & $0,60 \mathrm{aC}$ \\
\hline \multirow[t]{3}{*}{ Potāssio } & U2 & $3,00 \mathrm{aA}$ & $2,13 a B$ & $1,45 a C$ & $0,90 \mathrm{aD}$ \\
\hline & U3 & $2,81 \mathrm{aA}$ & $1,94 a B$ & $1,15 a b c$ & $1,01 \mathrm{aC}$ \\
\hline & UI & $0,73 a A$ & $0,63 \mathrm{abA}$ & $0,50 \mathrm{aB}$ & $0,43 a \mathrm{~B}$ \\
\hline \multirow[t]{3}{*}{ Cälcio } & U2 & $0,53 \mathrm{bA}$ & $0,56 \mathrm{bA}$ & $0,46 \mathrm{aAB}$ & $0,40 a B$ \\
\hline & U3 & $0,64 a A$ & $0,66 a A$ & $0,51 \mathrm{aB}$ & $0,40 \mathrm{aC}$ \\
\hline & UI & $0,47 \mathrm{aA}$ & $0,45 \mathrm{aA}$ & $0,36 \mathrm{aB}$ & $0,34 \mathrm{aB}$ \\
\hline \multirow[t]{3}{*}{ Magnés io } & U2 & $0,30 \mathrm{aB}$ & $0,37 \mathrm{bAB}$ & $0,40 \mathrm{aA}$ & $0,36 \mathrm{aAB}$ \\
\hline & U3 & $0,40 \mathrm{aB}$ & $0,48 \mathrm{aA}$ & $0,40 \mathrm{aB}$ & $0,37 \mathrm{aB}$ \\
\hline & UI & $0,38 a A$ & $0,25 a B$ & $0,17 a c$ & $0,15 a c$ \\
\hline \multirow[t]{2}{*}{ Enxôfre } & U2 & $0,34 a b A$ & $0,28 a B$ & $0,21 a C$ & $0,17 a c$ \\
\hline & U3 & $0,32 \mathrm{bA}$ & $0,30 a A$ & $0,21 a B$ & $0,18 a B$ \\
\hline
\end{tabular}

(a) Valores para o mesmo mineral, seguidos da mesma letra minúscula nas colunas não têm diferença significativa $(P \leqslant 0,05)$. Valores para o mesmo mineral, seguidos da mesma letra maiúscula nas $1 i$ nhas não têm diferença significativa $(P \leqslant 0,05)$.

(b) Dias apōs a imposição dos tratamentos. 
Tabela 8 - Conteúdo (a) mg na parte aérea) de minerais em épocas distintas $^{(b)}$ em capim tobiatã (Panicum maximum cv. Tobiatã) submetido a diferentes regimes de umidade do solo

\begin{tabular}{|c|c|c|c|c|c|}
\hline \multirow{2}{*}{ MINERAL } & \multirow{2}{*}{$\begin{array}{c}\text { Regime de } \\
\text { Umidade }\end{array}$} & \multicolumn{4}{|c|}{ Epocas $^{(b)}$} \\
\hline & & 7 & 14 & 21 & 28 \\
\hline & UI. & $69,0 a A B$ & $63,3 \mathrm{aB}$ & $65,3 a B$ & $83,7 \mathrm{aA}$ \\
\hline \multirow[t]{3}{*}{ Fösforo } & U2 & $36,0 \mathrm{bB}$ & $38,0 \mathrm{bAB}$ & $45,3 \mathrm{bAB}$ & $52,0 \mathrm{bA}$ \\
\hline & U3 & $47,0 \mathrm{BA}$ & $49,7 a b A$ & $50,7 \mathrm{bA}$ & $48,7 \mathrm{bA}$ \\
\hline & UI & $711,3 \mathrm{aA}$ & $571,7 a B$ & $465,3 \mathrm{aBC}$ & $443,0 \mathrm{aC}$ \\
\hline \multirow[t]{3}{*}{ Potássio } & U2 & $522,0 \mathrm{bAB}$ & $533,0 \mathrm{aA}$ & $506,3 \mathrm{aAB}$ & $413,0 \mathrm{aB}$ \\
\hline & U3 & $585,0 \mathrm{bA}$ & $549,0 \mathrm{aA}$ & $472,7 a A B$ & $407,7 \mathrm{aB}$ \\
\hline & U & $223,3 a B$ & $273,0 \mathrm{aAB}$ & $320,0 \mathrm{aA}$ & $319,7 \mathrm{aA}$ \\
\hline \multirow[t]{3}{*}{ Cálcio } & U2 & $94,0 \mathrm{bB}$ & $139,7 \mathrm{bAB}$ & $164,7 \mathrm{bA}$ & $184,7 \mathrm{bA}$ \\
\hline & U3 & $133,7 \mathrm{bB}$ & $188,7 \mathrm{bAB}$ & $208,7 \mathrm{bA}$ & $161,0 \mathrm{bAB}$ \\
\hline & UI & $142,3 a C$ & $194,0 \mathrm{aB}$ & $226,7 \mathrm{aAB}$ & $247,7 \mathrm{aA}$ \\
\hline \multirow[t]{3}{*}{ Magnésio } & $\mathrm{U} 2$ & $53,0 \mathrm{bB}$ & $91,7 \mathrm{CB}$ & $142,7 \mathrm{bA}$ & $113,3 \mathrm{bA}$ \\
\hline & U3 & $84,7 \mathrm{bB}$ & $138,7 \mathrm{bA}$ & $165,3 \mathrm{bA}$ & $151,0 \mathrm{BA}$ \\
\hline & UI & $116,7 \mathrm{aA}$ & $108,0 \mathrm{aA}$ & $108,0 \mathrm{aA}$ & $110,3 a A$ \\
\hline \multirow[t]{2}{*}{ Enxôfre } & U2 & $62,0 \mathrm{bA}$ & $70,3 \mathrm{bA}$ & $73,3 \mathrm{bA}$ & $78,7 \mathrm{bA}$ \\
\hline & U3 & $68,0 \mathrm{bA}$ & $85,0 \mathrm{abA}$ & $84,7 \mathrm{abA}$ & $75,7 \mathrm{bA}$ \\
\hline
\end{tabular}

(a) Valores para o mesmo mineral, seguidos da mesma letra minüscula nas colunas não têm diferença significativa $(P \leqslant 0,05)$. Valores para 0 mesmo mineral, seguidos da mesma letra maiúscula nas linhas não têm diferença significativa $(P \leqslant 0,05)$.

(b) Dias após a imposição dos tratamentos. 


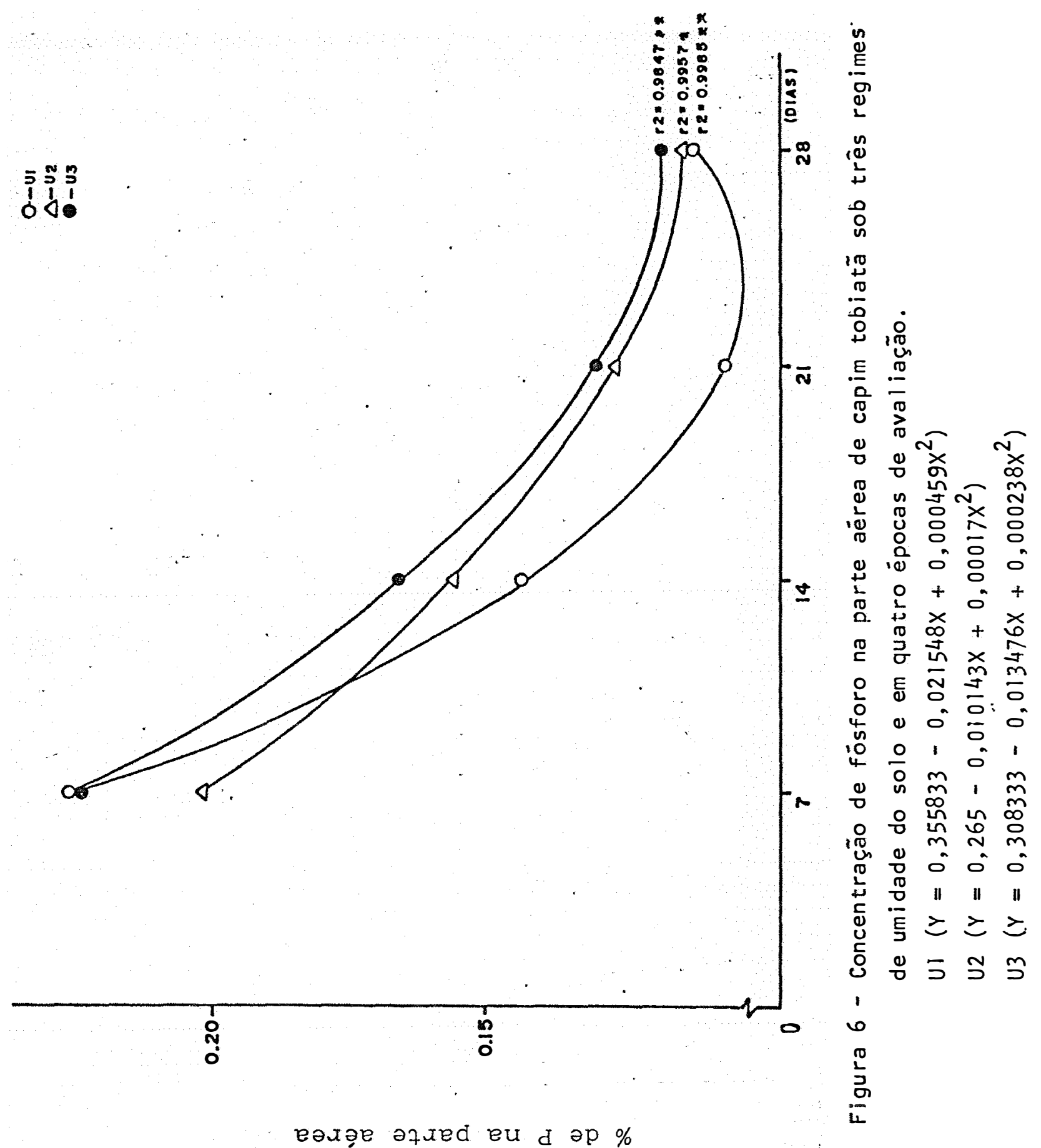


produção de matēria seca destas plantas em relação a U2 e U3.

$$
\text { Observa-se (Tabela 7) decrēscimo significạ }
$$

tivo da concentração do fósforo a medida que as plantas desenvolvem-se sob efeito de todos os tratamentos. Aos 28 dias, época da ültima avaliação, a concentração de fós foro jā era semelhante para os regimes hidricos estudados.

A menor concentração do fósforo nas plantas que cresceram sob regime Ul pode ser explicada pelo desen volvimento ontogênico mais acelerado destas plantas que, proporcionalmente aos demais tratamentos teriam maior quan tidade de tecido fisiologicamente mais velho e mais pobre em P, uma vez que o aumento da idade da planta (envelhec mento do tecidol leva ao decréscimo da concentração de fósforo do tecido vegetal (MENGEL e KIRKBY, 1982). Em ad ção a este fato sabe-se que a absorção de $P$ è prejudicada pelo aumento da idade da planta (BARBER, 1980) devido ao reduzido influxo de $P$ através das raizes velhas ou suber zadas; sendo possível tambēm, segundo o mesmo autor, haver uma redução de absorção de $P$ mesmo por raízes jovens provenientes de plantas mais velhas.

Quando o conteúdo de fósforo foi expresso de forma absoluta (mg de $P$ na parte aérea) ocorreu uma tendên cia oposta, isto é, o aumento do estresse de umidade provocou um decréscimo na absorção total de P pela plantalfí 
gura 7 e Tabela 8 ). Tendência semelhante foi também observada por GERAKIS et alii (1975) em Erodium botrys e Bro mus mollis submetidos a estresse hidrico. Segundo GREENWAY e KLEPPER (1968) existe um efeito marcante do fluxo de água através da raiz e no interior do xilema, não na taxa de absorção de $P$, mas na taxa em que $P$ previamente ab sorvido é transferido para o xilema, e consequentemente pa ra a parte aérea. 0 processo, segundo estes autores, seria que o fluxo de transpiração, por induzir um movimento mais rápido do $P$ através do simplasto, pode diluir a concentração deste elemento no seu interior e como resultado promo ver a transferência para a parte aérea ao invēs do acūmulo nos vacūolos das células radiculares. Considerando - se que as plantas em Ul, devido a maior umidade do solo e maior superficie fotossintētica, apresentaram maior transpiração que as plantas de U2 e U3, infere-se que o fluxo de água teve grande influência na variāvel absorção de $P$ (mg de $P$ na parte aérea.

Analisando-se a Figura 7 é possível ainda ob servar que ocorreu tendência de aumento do conteúdo absoluto de $P$ pelas plantas através do tempo sob os regimes hidri cos estudados. Entretanto, para U1, no 14 ? dia de avaliação, houve tendência de diminuição no conteúdo de fósforo, sugerindo que o aumento $(P<0,05)$ na produção de matēria seca (Tabela 6) entre as épocas 1 e 2 não foi capaz de provocar diluição significativa no teor de fósforo, o que indica que a condição de absorção desse nu- 


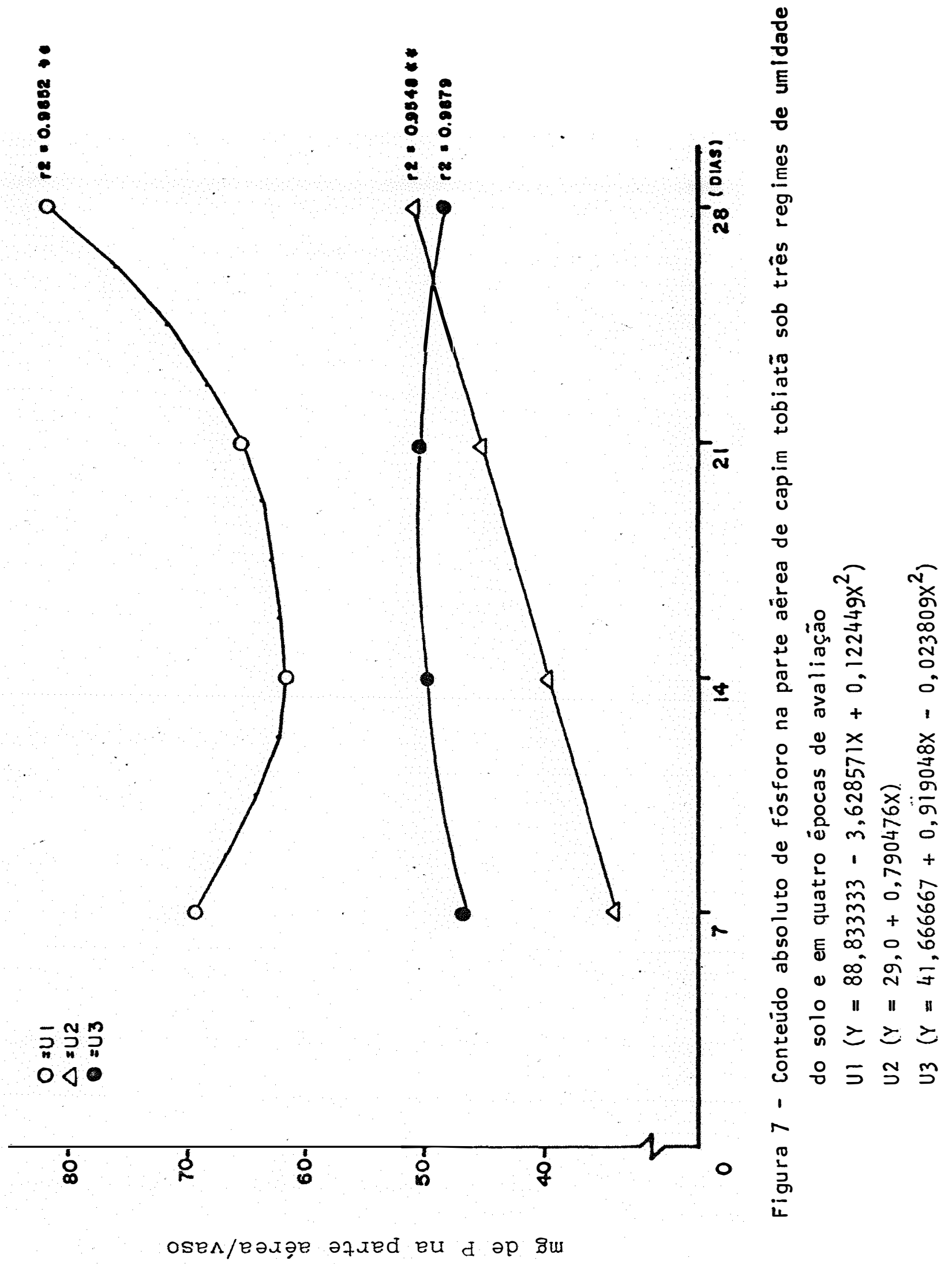


triente era suficiente para manter a exigencia da planta. Por outro lado, em U3 a tendência de decréscimo na absorção de fösforo ao final do experimento pode indicar que o nivel de estresse experimentado pela planta estaria mostrando os primeiros sinais de limitação à produção de matēria seca e absorção do fósforo.

Os resultados demonstram que interpretações das anālises de composição bromatológica em relação ao fós foro dependem de conhecimentos sobre ontogenia da planta, estägio de desenvolvimento e nivel de estresse hídrico, in formações que não são facilmente coletadas e disponíveis.

\subsubsection{Potäs sio}

o estresse de umidade esteve associado com aumento na concentração de K da planta (Tabela 7 e Figura 8). Já a partir da primeira época de avaliação os valores para esta variável eram semelhantes entre U2 e U3 e significativamente $(P<0,05)$ maiores a UI. A diferença na concentração de K entre tratamentos diminuiu à medida que as plantas se desenvolveram e, aos 28 dias, durante a ültima avaliação, a concentração de K era semelhante variando de 0,6 a $1,0 \%$ (Tabela 7 ). Sabe-se que o aumento de $K$ no conteüdo celular, em condições de mais baixo nivel de água no solo, pode ser provocado pelo mecanismo de adaptação da planta ao estresse hídrico, já que este ion é um importante soluto envolvido no ajuste osmó- 


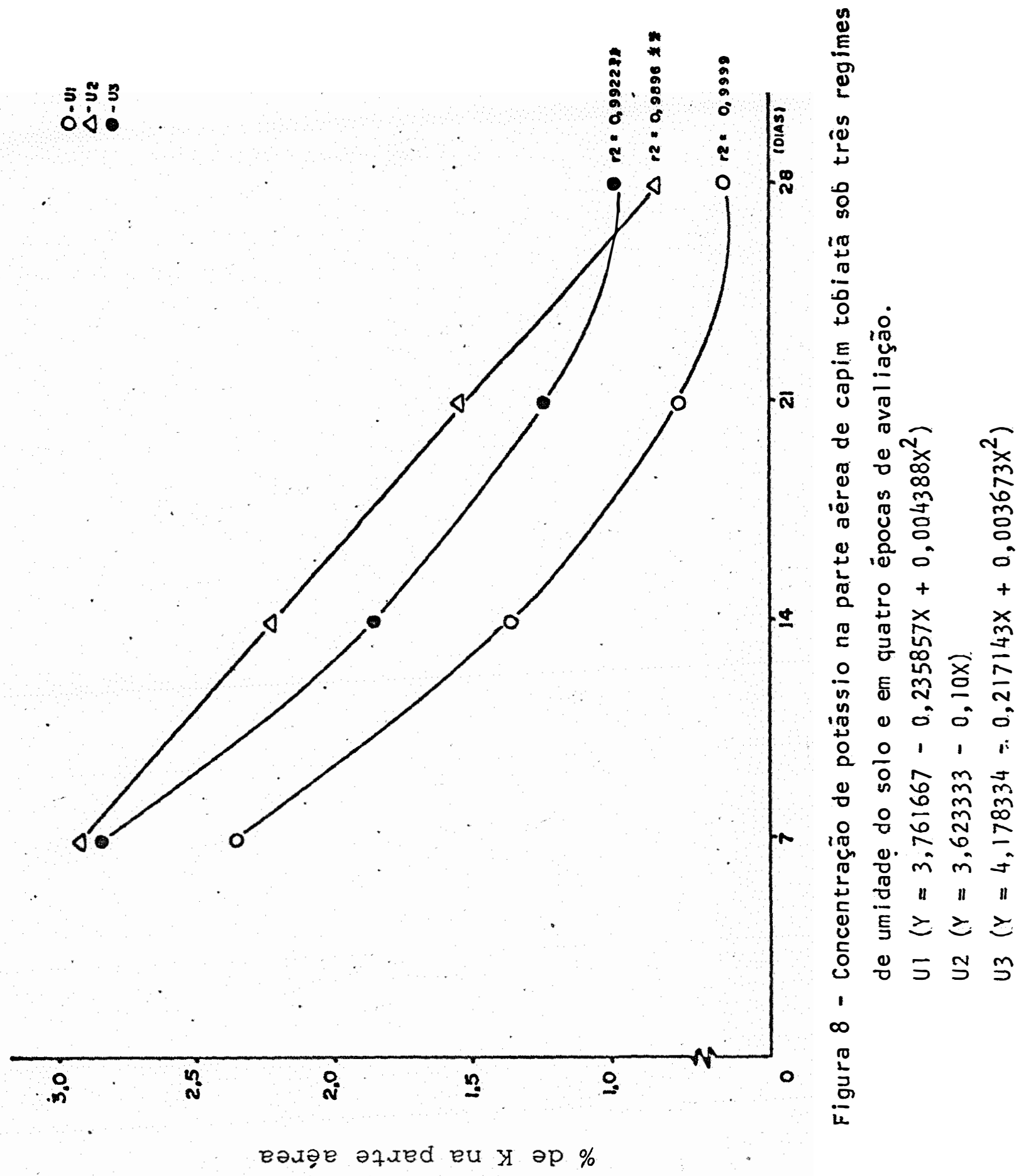


tico (aumento no nível de soluto devido à perda de água) nas células da folha a fim de manter a turgidez e fixação de $\mathrm{CO}_{2}$ (TURNER e BEGG, 1978; PITMAN, 1981).

FORD e WILSON (1981) mostraram também haver um grande acümulo de potássio nas folhas de Heteropogon contortus e cenchrus ciliaris submetidos a estresse hidr co, sendo esta característica atribuida como causa do papel da regulação osmōtica desempenhado por este cátion em muitas espécies. Pode ser afirmado portanto que os resultados observados no estudo anterior justificam o aumento na concentração de $K$ encontrado no presente trabalho para as plantas estressadas, sugerindo portanto que nesta situação este ion estava sendo utilizado preferencialmente na regulação osmōtica do que diretamente no metabolismo de crescimento da planta.

A absorção de $K$ (mg de K na parte aērea) foi relativamente pouco afetada pelo estresse hídrico (Tabela 9). De acordo com PITMAN (1981) a absorção de K de solu ções se mantêm mesmo sob baixas taxas de fluxo de água, sendo que dentro da planta o transporte de $K$, ao contrário do Ca e Mg e sulfato, seria menos afetado pelo baixo fluxo de ãgua de natureza espasmödica. Tal condição, segundo BOWLING (1968), seria mais evidente em situações de baixas concentrações externas de $K$ na solução. Em trabalho desenvolvido com girassol, este ültimo autor determi- 


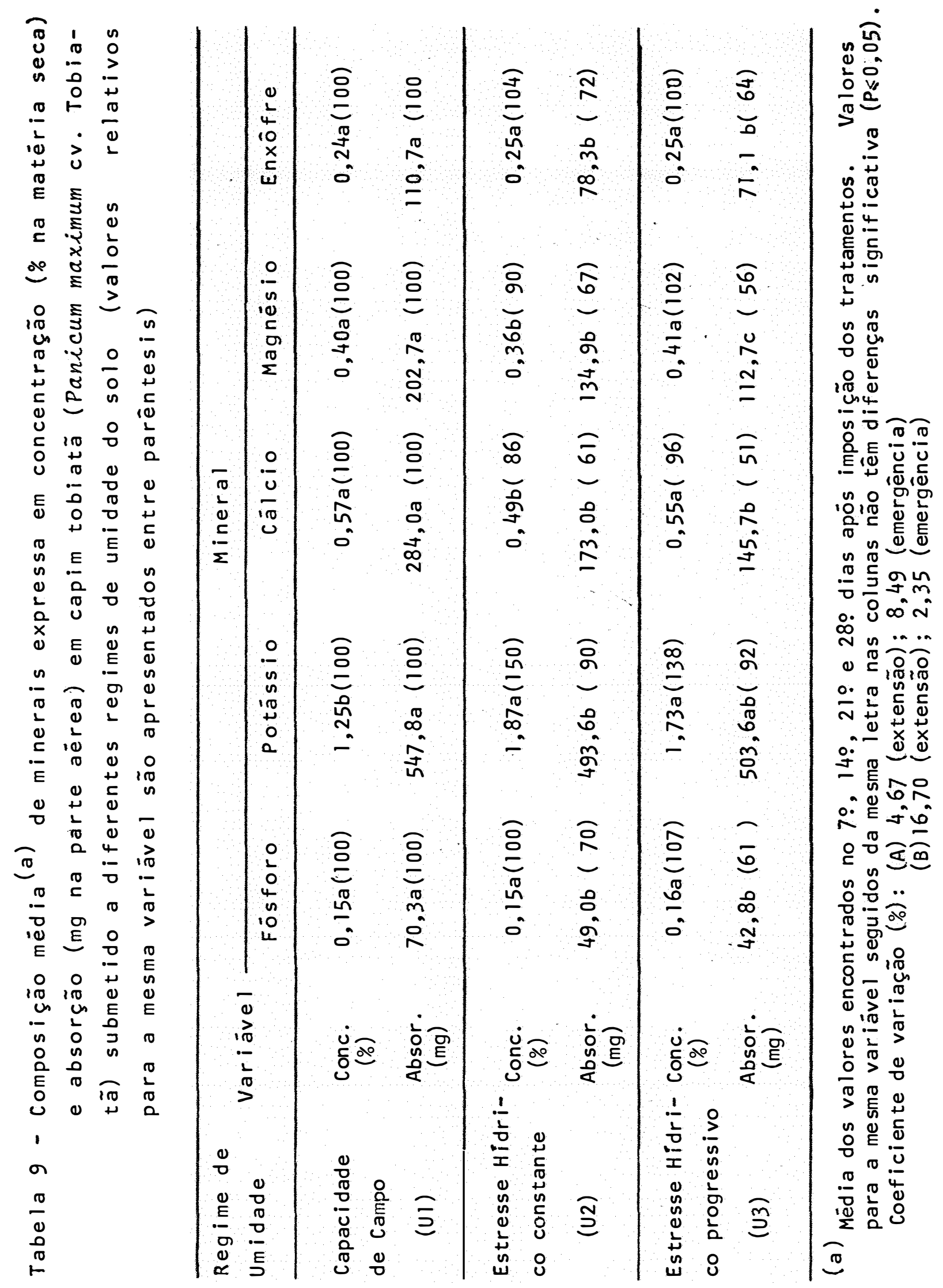


nou que quando a concentração externa de $K$ é alta, a transpiração parece ter efeito marcante no fluxo passivo de absorção do $K$, por outro lado, sob concentrações externas baixas de $K$, onde o transporte de $K$ para a parte aērea é principalmente um processo ativo, não hä efeito da transpiração. De fato, segundo CHEESMAN e HANSON (1979) a absorção de $K$ é ativa sob baixas, concentrações deste nutriente na solução do solo, sendo este mecanismo inibido por concentrações externas mais altas deste cation.

O manejo de adubação utilizado no presente ensaio (apenas uma fertilização no plantio) pode ter sido insuficiente para manter esse nutriente em disponibilidade às plantas durante toda a fase experimental, esgotando- se progressivamente com o decorrer do tempo. Esta condição, aliada às evidências acima apresentadas, pode ter contribuído para que, com exceção da primeira avaliação quando a concentração de $K$ na solução do solo era ainda provavelmente alta, os valores para a absorção de K tenham sido semelhantes entre todos os tratamentos (Figura 9 e Tabela 8).

Sendo assim, o valor significativamente maior para a absorção de K pelas plantas da Ul em relação a U2 e U3 encontrado na primeira época de avaliação (Tabela 8) podé portanto traduzir um efeito direto do fluxo de ägua 


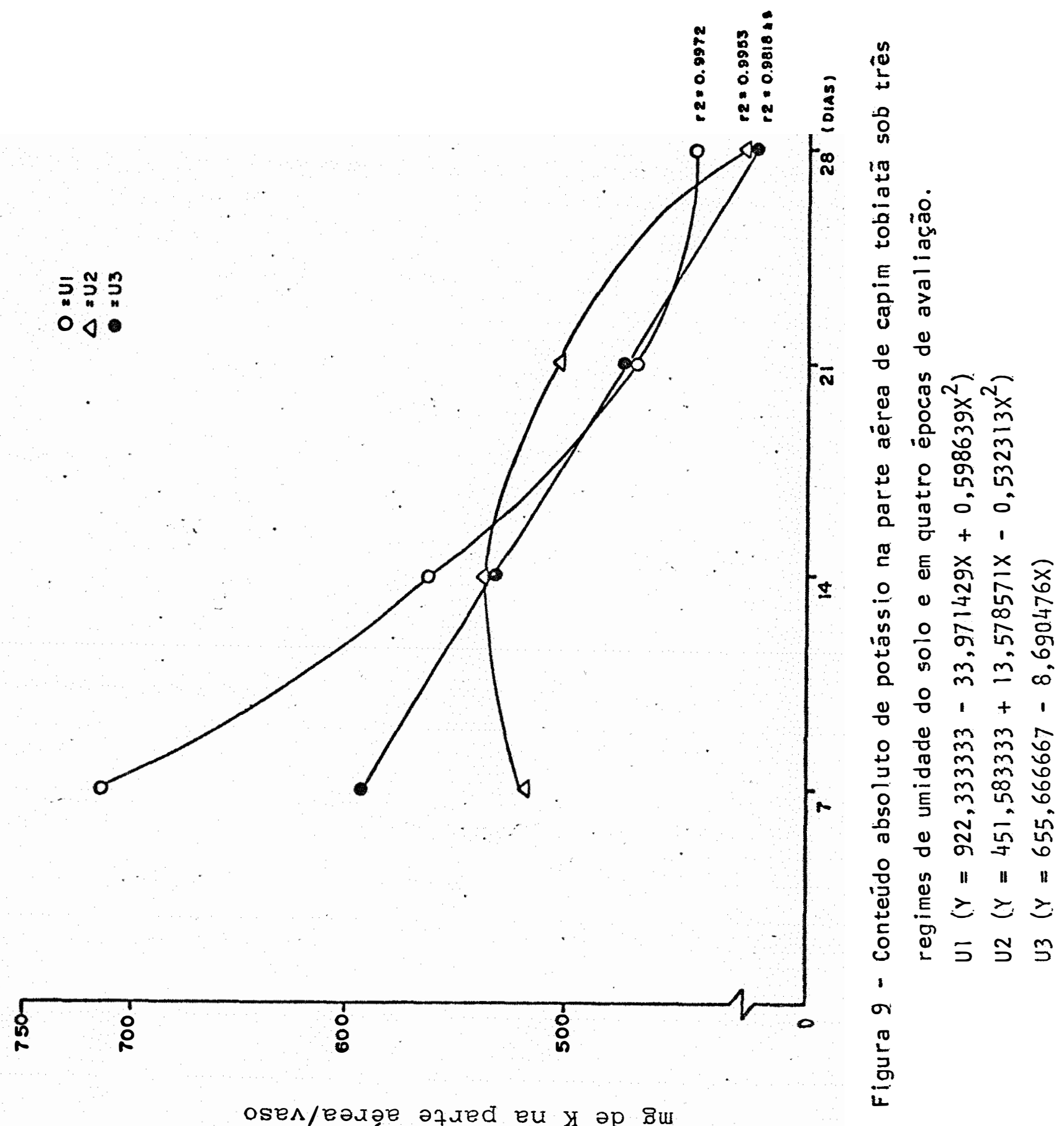


causado pela maior transpiração das plantas submetidas a este tratamento.

\subsubsection{Càlcio e Magnésio}

o estresse hídrico influenciou negativamente no conteūdo absoluto de Ca na parte aérea (Figura lo e Tabela 8). Comportamento semelhante foi também encontrạ do para o Mg (Figura ll e Tabela 8). GERAKIS et alii (1975) encontraram também a mesma tendência ém Erodium bro tys e Bromus mollis. E sabido que o Ca tem a absorção e translocação dentro da planta comandadas principalmente por um processo passivo, sendo a intensidade de transpiração (fluxo de āgua na planta) a principal responsāvel pela translocação ascendente de Ca (PITMAN, 1981; MENGEL e KIRKBY, 1982). Em condições de baixa transpiração existe depressão na taxa de absorção de Ca e Mg (LAZARoff e PITMAN, 1966; PITMAN, 1981).

Examinando-se os valores médios relativos referentes ao conteūdo absoluto de Ca e Mg (Tabela 9) a caracteristica acima descrita pode ser prefeitamente visualiza da; sob efeito do estresse hídrico a redução na absorção des ses minerais variou entre 51 e $67 \%$ do tratamento Ul, onde as plantas apresentavam maior superficie foliar e condições para maior taxa de transpiração. Em algumas situações foi ob- 


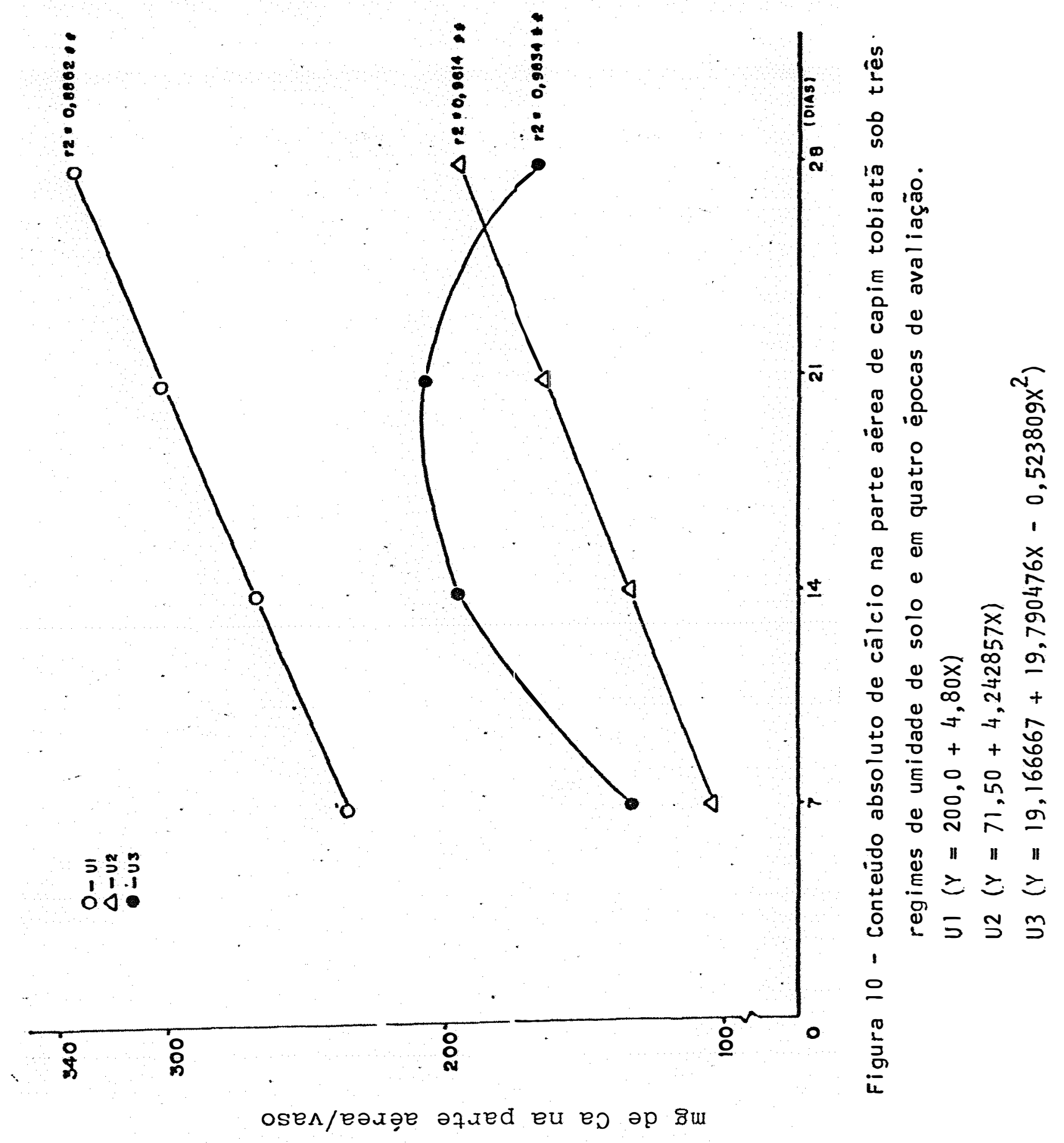




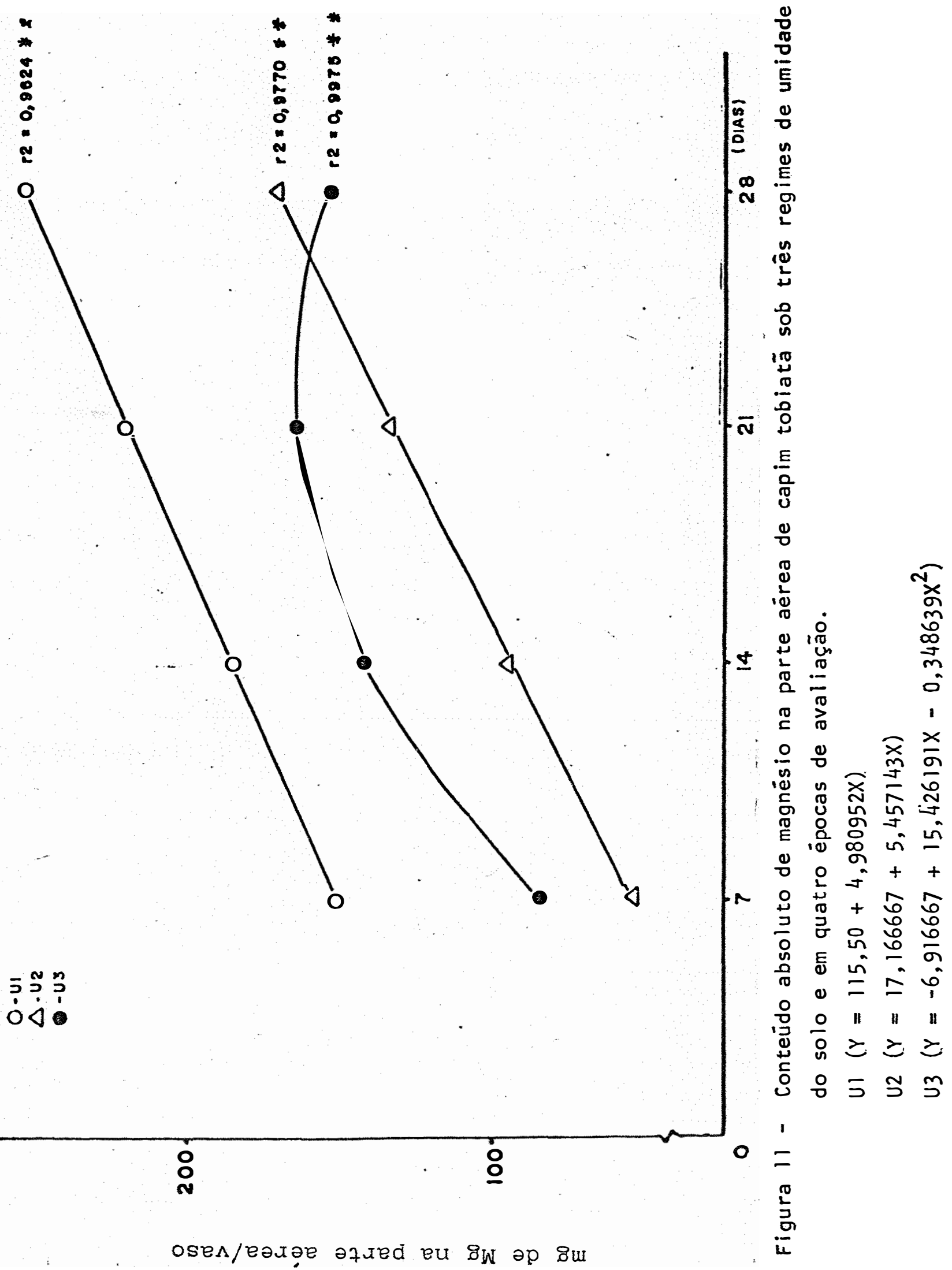


servada perda de até $1000 \mathrm{ml}$ de àgua, por vaso, no trata mento Ul, em período de cerca de seis horas (dados não apre sentados). Essa perda de àgua pode ser atribuída, em gran de parte, a transpiração jä que, com base em experimento anterior (M.B. DIAS FILHo, não publicado), a evaporação mostrou ser insignificante nestas condições.

A concentração de Ca (Figura 12 e Tabela 7), independente do nível de umidade do solo, apresentou decréscimo com a idade da planta, variando de em média $0,6 \%$ aos sete dias para $0,4 \%$ aos 28 dias de avaliação. Por outro lado, o Mg mostrou aumentos significativos nas avaliações aos 14 e 21 dias para os tratamentos U3 e U2, respectivamente (Tabela 7 e Figura 13). Acredita-se que esse efeito seja devido à diminuição do nivel de K no solo, uma vez que GRIMME et alii (1974) determinaram o efeito antagônico do K na absorção do Mg'. De fato, comparando-se as Figuras 9 e 11 pode ser observado um efeito inverso entre a absorção destes dois cátions pe las plantas de capim tobiatã.

\subsubsection{Enxôfre}

A concentração de enxôfre na matēria seca não foi afetada pelo estresse de umidade (Tabela 7 e Figura 14). Por outro lado, houve absorção preferencial des te mineral pelas plantas do tratamento Ul (Tabela 8 e F gura 15), enquanto que o estresse hidrico (U2 e U3) prejú 


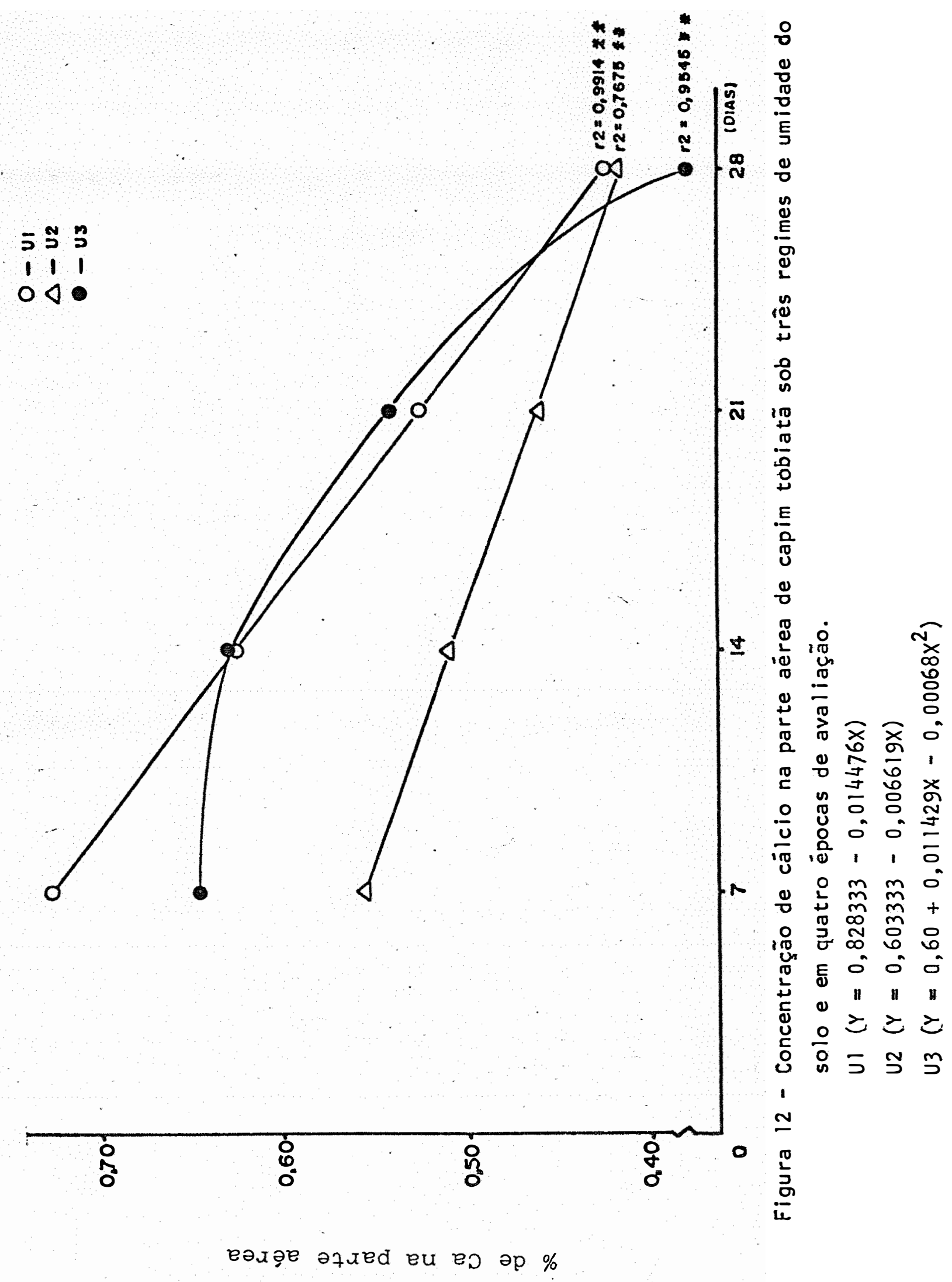




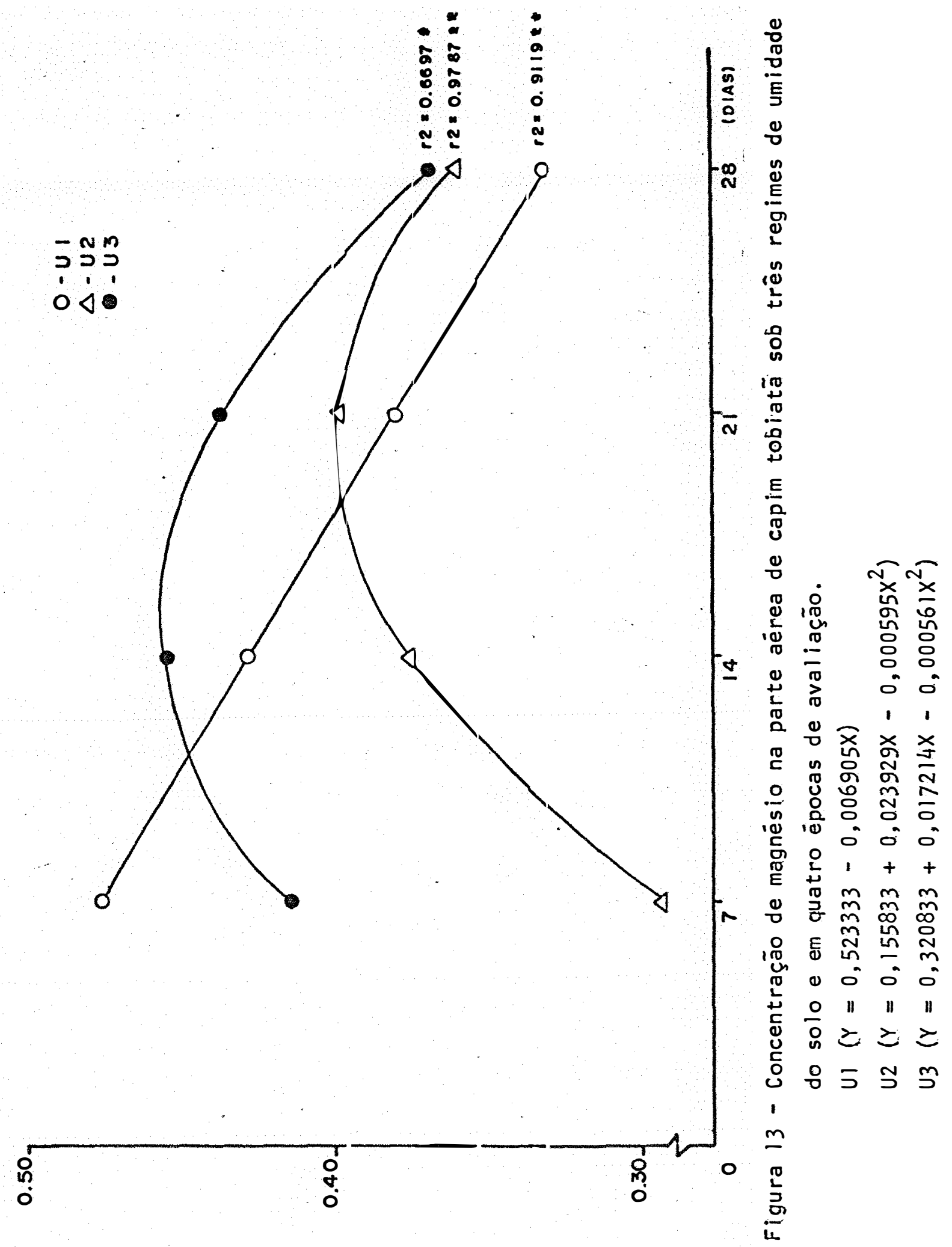

øuə 


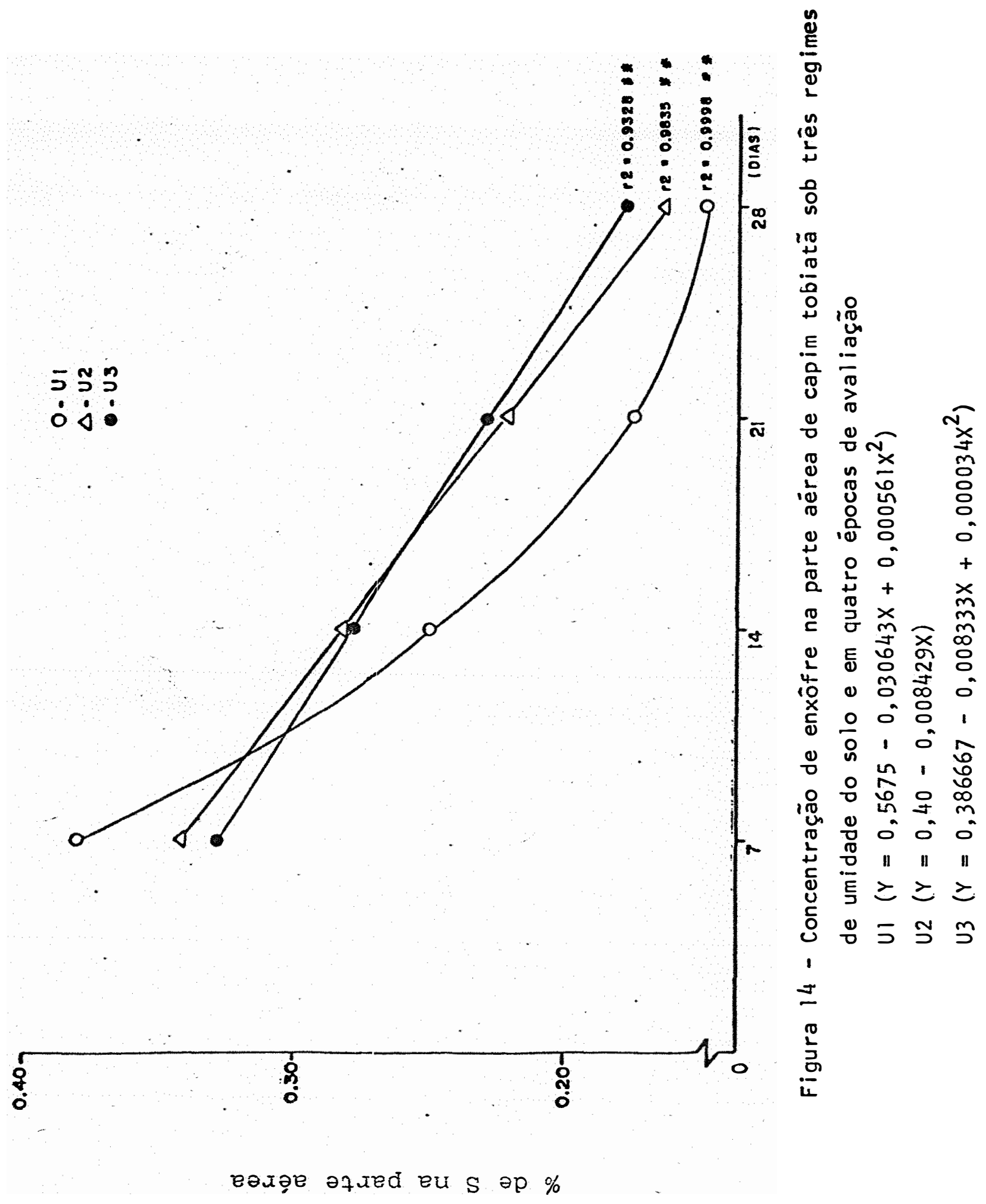




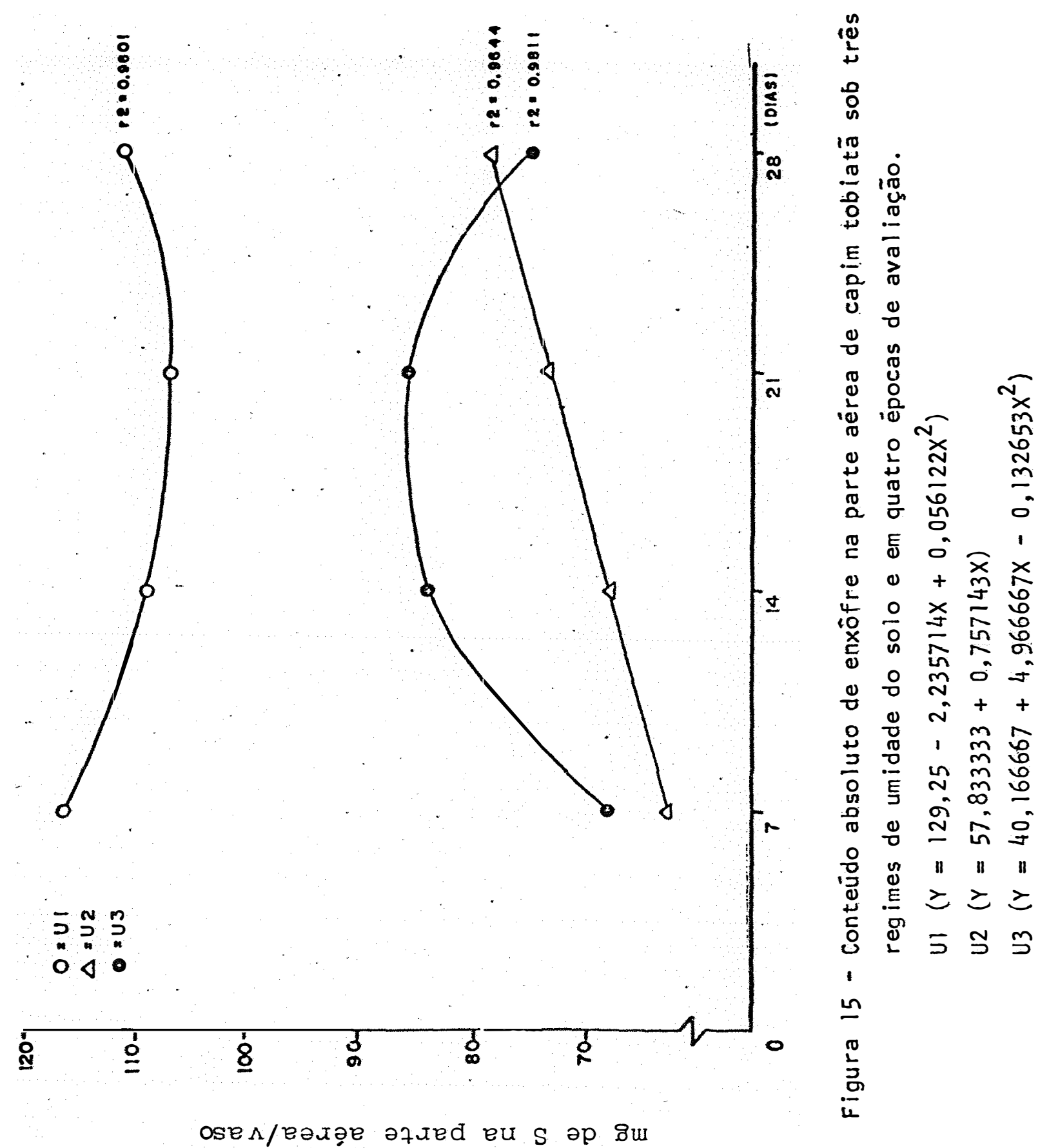


dicou significativamente a absorção do enxôfre pelas plantas. Dados de Petterson (1960), citados por PITMAN (1981) e dados de BOWLING (1968) mostram que plântulas de girassol absorveram o sulfato de maneira proporcional à transpiração (fluxo de àgua na planta).

\section{Comparando-se as Figuras 10,11 e $15 \mathrm{fica}$}

evidenciada a semelhança no comportamento da absorção entre o enxôfre, cálcio e magnésio, sugerindo mecanismos semelhantes de absorção destes minerais.

4.8.5. Eficiência de uso de fósforo e potássio

A eficiencia de uso de $P$ e K (EUP e EUK) foi negativamente influenciada pelo estresse hidrico (Figura 16), principalmente com relação ao K.

A magnitude, com relação aos valores médios observados para os três tratamentos, foi máxima para EUP (462-869 g de matēria seca/g de P absorvido); para o K esta amplitude foi menor $(38-126 \mathrm{~g}$ de matéria seca/g de $\mathrm{K}$ absorvido).

Observa-se que tanto a EUP como a EUK, este ültimo de maneira mais evidente, aumentaram com a ida de da planta e diminuiram com a intensidade do déficite de àgua do solo (Figura 16). De forma contrária, MISHA e SINGH (1982) ao avaliarem, em condições de campo, os efeitos 


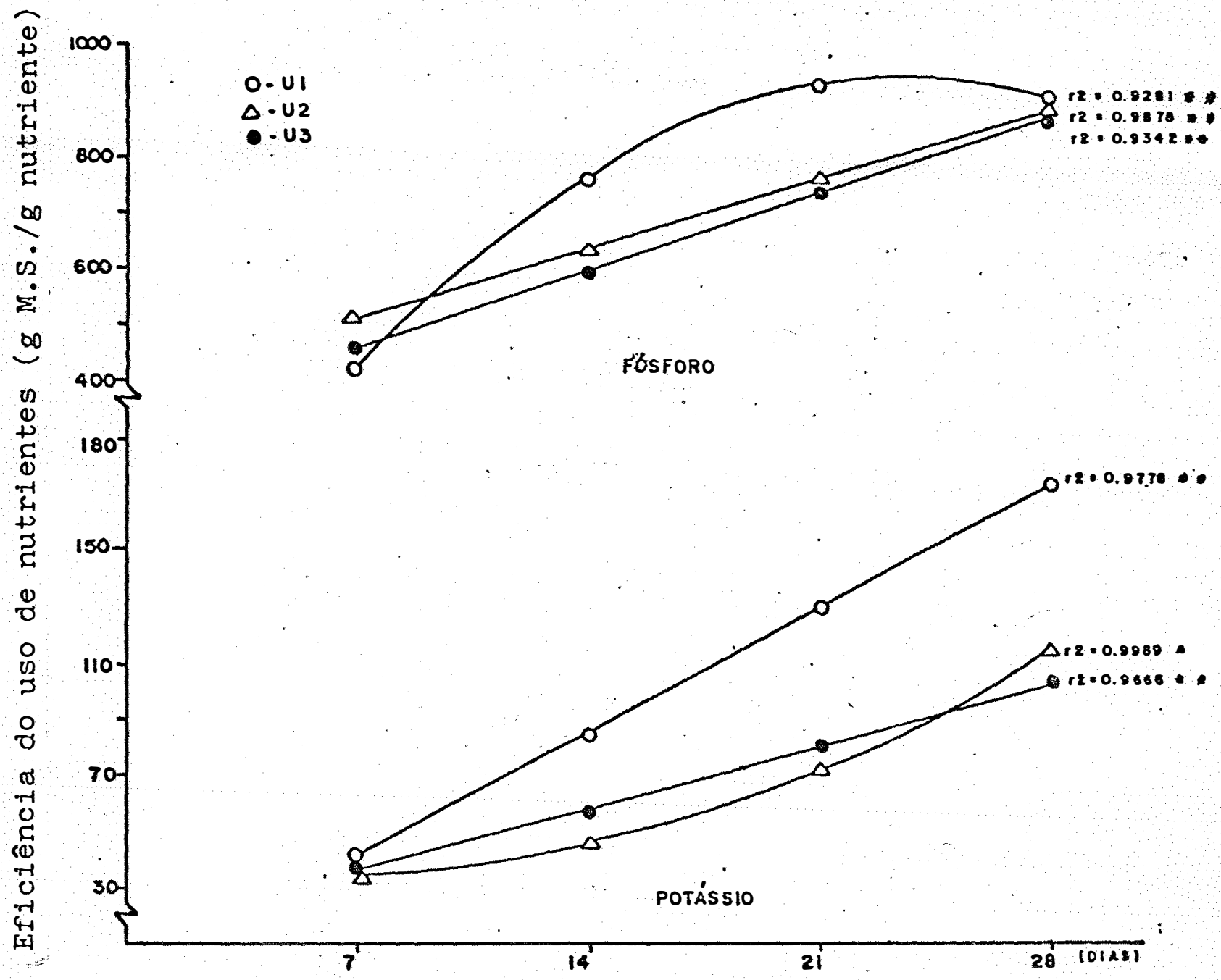

Figura 16 - Eficiência do uso de fósforo e potässio em capim tobiatã sob três regimes de umidade do solo e em quatro épocas de avaliação.

U1 $\left(P \rightarrow Y=-91,166667+85,819048 X-1,789116 X^{2}\right.$;

$$
K \rightarrow Y=-2,0+6,195238 X)
$$

U2 $(P \rightarrow Y=379,5+18,447619 x$;

$$
\left.K \rightarrow Y=37,083333-1,459524 X+0,147959 X^{2}\right)
$$

$U 3(P \rightarrow Y=316,166667+20,161908 x$;

$$
K \rightarrow Y=12,166667+3,228571 X)
$$


do estresse hidrico em gramíneas forrageiras $C_{4}$ no verão, encontraram tendência de aumento na EUK e EUP com o aumento do estresse hidrico.

0 aumento na EUK foi mais evidente para as plantas que não sofreram estresse hídrico (UI). Esse fato pode estar relacionado com o uso do K para a regulação osmótica pelas plantas sob efeito de estresse hidrico (FORD e WILSON, 1981). No entanto, MORGAN (1984) afirma que o mecanismo de regulação osmótica nao é simplesmente um acúmulo passivo de solutos que não puderam ser utilizadas devido a reduções no crescimento da planta. No presente trabalho a menor eficiencia no uso de K em U2 e U3 deveu - se ainda, provavelmente, a falta de condições de crescimento da planta em relação ao estresse hídrico combinado com a restrição na absorção de outros nutrientes pelas plantas estressadas como enxôfre, cálcio e magnésio. Deve-se salientar que a absorção de K foi pouco afetada pela condição de umidade do solo (Tabela 6 ), indicando que a redução na produção de matéria seca da parte aérea,particularmente, foi responsāvel pela diminuição da EUK. 


\section{CONCLUSÖES}

As seguintes conclusões são sugeridas dos resultados obtidos ao longo do desenvolvimento deste expe rimento.

a) 0 efeito prejudicial do estresse hídri co sobre o capim Panicum maximum cv. Tobiatã manifestouse na seguinte ordem decrescente de intensidade: matēria orgânica da raiz, peso seco da parte aérea, taxa de expan são foliar, nümero de folhas por planta, nümero de perfilhos e nümero de folhas por perfilho. Essas variäveis, respectivamente, para os tratamentos em que as plantas sofreram estresse hídrico constante - U2 $(29 \%$ de ägua no solo) e progressivo - U3 (37 a $27 \%$ de agua no solo), apre sentaram os seguintes valores mēdios em relação a UI ( $45 \%$ de àgua no solo), com as amplitudes de variação em parêntesis: $58(50$ a 70$)$ e $59(56$ a 80$) ; 59(56$ a 62) e 62 $(55$ a 68): $71(105$ a 53) e $68(101$ a 20); $75(69$ a 94) e 
$76(61$ a 96); $79(73$ a 91) e $87(80$ a 100$) ; 88(103$ a 90) e $96(102$ a 75$)$.

b) O decréscimo acentuado na massa radicular e na expansão foliar das plantas sob estresse hídrico, mesmo sob condições adequadas de fertilidade do solo, indi ca que o manejo e utilização da pastagem nestas condições deve merecer cuidados uma vez que estas plamtas teriam limitada capacidade de recuperação após o corte mecânico ou pastejo.

c) A redução na produção de matēria seca devido ao estresse hídrico pode ser indicação de estágio avançado do prejuízo provocado pela insuficiência de àgua para a planta, sendo consequência de reduções antecipadas de expansão foliar, nümero de folhas por planta além da diminuição do sistema radicular. Assim, plantas que demonstram redução na produção de matēria seca da parte aérea sob efeito do estresse hidrico devem responder mais lentamente a técnicas de manejo em decorrência do estágio avançado de deterioração no vigor da planta forrageira.

d) Os valores mëdios apresentados para as variáveis expansão foliar, nümero de follhas por planta e produção do sistema radicular encontrados neste estudo podem não representar somente o efeito dos tratamentos impostos uma vez que nas avaliações finais mediu-se uma somatöria de efeitos, refletindo esgotamento de nutrientes 
disponiveis, ontogenia diferencial de plantas e restrição do volume de solo, entre outros.

e) Plantas inicialmente submetidas a melhor condição de umidade do solo parecem sofrer mais os efeitos negativos de determinado estresse hidrico do que plantas que já experimentavam condições idênticas de estresse.

f) As quantidades de $\mathrm{Ca}, \mathrm{Mg}$ e $\mathrm{S}$ absorvidas (mg do mineral na parte aérea) pelas plantas podem ser boas indicadoras do estresse hidrico uma vez que experimentam reduções significativas nestas condições. Por outro lado, o K absorvido não indicaria intensidade de estresse hídrico na planta.

g) Plantas cultivadas em condições de campo devem apresentar comportamento semelhante aos efeitos morfofisiológicos determinados neste estudo. Reconhece-se, entretanto, que no campo as plantas apresentariam sinais menos evidentes e caracterizados em maior periodo de tempo devido às condições favoráveis de adaptação. 


\section{LITERATURA CITADA}

ABDEL RAHMAN, A.A.; A.F. SHALABY e M.0. EL MONAYERI, 1971. Effect of moisture stress on metabolic products and ions accumulation. Plant and Soil. The Hague, 34:65-90.

ACEVEDO, E.; T.C. HSIAO e D.W. HENDERSON, 1971. Immediate and subsequent growth response of maize leaves to changes in water status. Plant Physiology. Lancaster, 48:631-636.

BADE, D.H.e B.E. CONRAD, 1985. Temperature and water stress effects on growth of tropical grasses. Journal of Range Management. Denver, 38:321-324.

BARBER, S.A., 1980. Soil plant interactions in the phosphorus nutrition of plants. In: F.E. KHASAWNEH; E.C. SAMPLE E.J. KAMPRATH, Ed. The Role of Phosphorus in Agriculture. American Society of Agronomy, p. 591-615.

BEGG, J.E. e N.C. TURNER, 1976. Crop water deficits. Aduances in Agronomy. New York, 28:161-217. 
BEGG, J.E., 1980. Morphological adaptations of leaves to water stress. In: N.C. TURNER e P.S. KRAMER, Ed. Adaptations of Plants to Water and High Temperature Stress. John Wiley and Sons, Inc. New York, p.33-112.

BOWLING, D.J.F., 1968. Active and passive ion transport in relation to transpiration in Helianthus annus. Planta. Berlin, 83:53-59.

BOYER, J.S., 1970. Leaf enlargement and metabolic rates in corn soybean and sunflowers at various leaf water potentials. Plant Physiology. Lancaster, 46:233-235.

BOYER, J.S., 1985. Water transport. Annual Review of Plant Physiology. Palo Alto, 36:473-516.

CARTER, P.R.; C.C. SHEAFFER e W.B. WOORHEES, 1982. ROOt growth, herbage yield, and plant water status of alfalfa cultivars. Crop Science. Madison, 22:425-427.

CHEESMAN, J.N. e J.B. HANSON, 1979. Energy-linked potassium influx as related to cell potential in corn roots. Plant Physiology. Lancaster, 64:842-845.

CHU, A.C.P.; H.G. MCPHERSON e G. HALLIGAN, 1979. Recovery growth following water deficits of different duration in prairie grass. Australian Journal of Plant Physiology. East Melbourne. 6:255-263. 
COOPER, P.J.M., 1983. Crop management in rainfed agriculture with special reference to water use efficiency. In: Nutrient Balance and the Need for Fertilizers in Semi-Arid and Arid Regions. Proceedings of the $17^{\text {th }}$ Colloquium of the International Potash Institute. Rabat, 1983. p.63-79.

CORLETO, A. e H.M. LAUDE, 1974. Evaluating growth potential after drought-stress. Crop Science. Madison, 14:224-227.

CORSI, M., 1984. Effects of nitrogen rates and harvesting intervals on dry matter production, tillering and quality of the tropical grass Panicum maximum, Jacq. Ohio, The Ohio State University, 125p. (Tese de Doutorado).

CRAFTS, A.S., 1968. Water deficits and physiological process. In: KOZLOWSKI, T.T. Ed. Water Deficits and Plant Growth, Vol. I1. Academic Press. New York. p. 85-133.

CUTLER, J.M.; D.W. RAINS e R.S. LOOMIS, 1977. Role of changes in solute concentration in maintaining favourable water balance in field-grown cotton. Agronomy Journal. Madison. $69: 773-779$

CUTLER, J.M. e D.W. RAINS, 1978. Effects of water stress and hardening on the internal water relations and osmotic constituents of cotton leaves. Physiologia Plantarum. Copenhagen, 42:261-268. 
DAVIDSON, R.L., 1969. Effects of soil nutrients and moisture on root/shoot ratio in Lolium perenne L. and Trifolium repens L. Annals of Botany. Oxford, 33:571-577.

ECK, H.V. e J.T. MUSICK, 1979. Plant water stress effects on irrigated grain sorghum. II. Effects on nutrients in plants tissues. Crop Science. Madison. 19:592-598.

FORD, C.W. e J.R. WILSON, 1981. Changes in levels of solutes during osmotic adjustment to water stress in leaves of four tropical pasture species. Australian Journal of Plant Physiology. East Melbourne, 8:77-91.

GERAKIS, P.A.; F.P. GUERREIRO e W.A. WILLIAMS, 1975. Growth water relations and nutrition of three grassland annuals as affected by drought. Journal of Applied Ecology. Oxford. $12: 125-135$

GALES, K., 1979. Effects of water supply on partitioning of dry matter between roots and shoots in Lolium perenne. Journal of Applied Ecology. 0xford. 16:863-877.

GREENWAY, H. e B. KLEPPER, 1968. Phosphorus transport to the xylem and its regulation by water flow. Planta. Berlin, $83: 119-136$

HSIAO, T.C., 1973. Plant responses to water stress. Annual Review of Plant Physiology. Palo Alto, 24:519-570. 
HSIAO, T.C. E E. ACEVEDO, 1974. Plant responses to water deficits water-use efficiency, and drought resistance. Agricultural Meteorology. Amsterdan, 59:59-84.

HUMPHREYS, L.R., 1981. Environmental adaptation of tropical pasture plants. Macmillian Publishers Ltd. London, p.83-94.

KLEINENDORST, A., 1975. An expansion of leaf growth after stress conditions. Netherland Journal of Agriculture Science. Wageningen, $23: 139-144$.

KRAMER, P.J., 1983. Water relations of plants. Academic Press. Inc. New York. 489p.

KRIZEK, D.T.; A. CARMI; R.M. MIRECKI; F.W. SNYDER E J.A.BUNCE, 1985. Comparative effects of soil moisture stress and restricted root zone volume on morphogenetic and physiological responses of soybean (Glycine max (L.) Merr.). Journal of Experimental Botany. 0xford. 36:141-148.

LANGER, R.H.M., 1963. Tillering in herbage grasses. Herbage Abstracts. Aberystwith, 33:141-148.

LAWLOR, D.W., 1969. Plant growth in polyethylen glycol solutions in relation to osmotic potential of the root medium and the leaf water balance. Journal of Experimental Botany. 0xford. 20:895-911. 
LAZAROFF, N. e M.G. PITMAN, 1966. Calcium and magnesium uptake by barley seedlings. Australian Journal of Biological Sciences. East Melbourne. 19:991-1005.

LEVITT, J., 1980. Response of plants to environment stress. Vol. Il. Water, radiation, salt and other stresses. Academic Press. New York, 607p.

LUDLOW, M.M. e T.T. NG, 1976. Effect of water deficit on carbon dioxide exchange and leaf elongation rate of Panicum maximaum var. trichoglume. Australian Journal of Plant Physiology. East Melbourne, 3:401-413.

LUDLOW, M.M. e T.T. NG, 1977. Leaf elongation rate in Panicum maximum var. trichoglume following removal of water stress. Australian Journal of Plant Physiology. East Melbourne, $4: 263-272$.

LUXMOORE, R.J. e R.L. MILLINGTON, 1971. Growth of perenial ryegrass (Lolium perenne L.) in relation to water, nitrogen and light intensity. 1. Effects on leaf growth and dry weight. Plant and Soil. The Hague, 34:269-281.

MAERTENS, C., 1981. Relations between the uptake of nutrients and water and the root system. In: Agricultural yield potentials in continental climates proceedings of the $16^{\text {th }}$ Colloquium of the International Potash Institute. p. 77-86. 
MALIK, R.S.; J.S: DHANKAR E N.C. TURNER, 1973. Influence of soil water deficits on root growth of cotton seedlings. Plant and Soil. The Hague. 53:109-115.

MARSCHNER, H. 1983. Nutrient mobility, root growth and root induced changes in the rhizosphere as factors of nutrient availability in soils of semi-arid and arid areas. In: Nutrient Balances and the need for Fertilizers in SemiArid and Arid Regions. Proceedings of the $17^{\text {th }}$ Colloquium of the International Potash Institute, Rabat, 1983. P. $107-128$.

MCCREE, K.H. e S.D. DAVIS, 1974. Effect of water stress and temperature on leaf size and number of epidermal cells in grain sorghum. Crop Science. Madison, 14:751-755.

McIVOR, J.G., 1984. Leaf growth and senescence in Urochloa mosanbiensis and $U$. oligotricha in a seasonally dry tropical environment. Australian Journal Agriculture Research. East Melbourne, 35:177-187.

MENGEL, K. e E.A. KIRKBY. Principles of plant nutrition. International Potash Institute. Bern. 655p.

MISRA, G. e K.P. SINGH, 1982. Effect of soil moisture and clipping stresses on the nutrient ( $N, P$ and $K$ ) concentration, uptaké and use efficiency in one temperate and two tropical grasses. Plant and Soil. The Hague, 69:413-421. 
MORGAN, J.M. 1984. Osmoregulation and water stress in higher plants. Annual Review of Plant Physiology. Palo Alto, 35: 299-319.

NG, T.T.; J.R. WILSON e M.M. LUDLOW, 1975. Influence of water stress on water relations and growth of a tropical $\left(c_{4}\right)$ grass Panicum maximum var. trichoglume. Australian Journal of Plant Physiology. East Melbourne, 2:581-595.

NORRIS, I.B., 1982. Soil moisture and growth of contrasting varieties of Lollium, Dactylis and Festuca species. Grass and Forage Science. Hurley, 37:273-283.

NORRIS, I.B. E H. THOMAS, 1982. Recovery of ryegrass species from drought. Journal of Agriculture Science. Cambridge, : $98: 623-628$.

OZANNE, P.G., 1980. Phosphate nutrition of plants - a general treatise. In: KHASAWNEH, F.E.; E.C. SPMPLE e E.J. KAMPRATH, Ed. The Role of Phosphorus in Agriculture. American Society of Agronomy. p.559-589.

PASSIOURA, J.B., 1981. Water collection by roots. In: L.G. PALEG e D.ASPINTAL, Ed. Physiology and Biochemistry of Drought Resistance in Plants. Academic Press. Sydney, p. $39-53$. 
PEACOCK, C.H. e A.E. DUDECK, 1995. Effect of irrigation interval on St. Augustinegrass rooting. Agronomy Journal. Madison, $77: 813-815$.

PEAKE, D.C.I.; D. STIRK and E.E. HENZEL, 1975. Leaf water potential of pastures plants in a semi-arid subtropical environment. Australian Journal of Experimental Agriculture and Animal Husbandry. East Melbourne, 15:645-654.

PROFFITT, A.P.B.; P.R. BERLINER E D.M. OOSTERHUIS; 1985. A comparative study of root distribution and water extration efficiency by wheat grown under high-and lowfrequency irigation. Agronomy Journal. Madison, 17:655-662.

REICHMAN, G.A. e D.L. GRUNES, 1966. Effect of water regime and fertilization on barley growth, water use, and $N$ and $P$ uptake. Agronomy Journal. Madison, 58:513-517.

RITCHIE, J.T., 1974. Atmospheric and soil water influences on the plant water balance. Agricultural Meteorology. Amsterdan, 14:183-198.

RITCHIE, J.T., 1981. Water dynamics in the soil-plant-atmosphere system. Plant and Soil. The Hague, 58:81-96.

SALINAS, J.G. e R. GARCTA, 1985. Métodos químicos para el anälisis de suelos ácidos y plantas forrajeras. Centro Internacional de Agricultura Tropical, Programa de Pastos Tropicales. Cali, Colombia. $83 p$. 
SILSBURY, J.H., 1970. Leaf growth in pasture grasses. Tropical Grasslands. St. Lucia, 4:17-36.

SHARP, R.E.C. e W.J. DAVIES, 1979. Solute regulation and growth by roots and shoots of water-stressed maize plants. Planta. Berlin, 149:43-49.

SHARP, R.E. e W.J. DAVIES, 1985. Root growth and water uptake by maize plants in drying soil. Journal of Experimental Botany. 0xford, 36:1441-1456.

SHARPLEY, A.N. e L.W. REED, 1982. Effect of environmental stress on the growth and amount and forms of phosphorus in plants. Agronomy Journal. Madison, 74:19-22.

THOMAS, H., 1980. Terminology and definitions in studies of grassland plants. Grass and Forage Science. Hurley, 35 : $13-23$

TURNER, N.C. e J:E. BEGG, 1978. Responses of pasture plants to water deficits. In: WILSON, J.R. Ed. Plant Relations in Pasture. CSIRO, St. Lucia, p.50-66.

TURNER, N.C. e J.E. BEGG, 1981. Plant water relations and adaptation to stress. Plant and Soil. The Hague, 58:97-132.

VIETS Jr., F.G., 1972. Water deficits and nutrient availability. In: KOZOLOWSKI, T.T. Ed. Water Deficits and Plant Growth. Vol. III. Academic Press. New York, p.217-339. 
WARDLOW, I.F., 1969. The effect of water stress on translocation in relation to photosynthesis and growth. II. Effect during leaf development in Lolium temulentum. Australian Journal of Biological Science. East Melbourne, 22:1-16.

WATTS, W.R., 1974. Leaf extension in Zea mays. III. Field measurement of leaf extension in response to temperature and leaf water potential. Journal of Experimental Botany. oxford, 25:1085-1096.

WESTGATE, M.E. e J.S. BOYER, 1985. Osmotic adjustment. and the inhibition of leaf, root, stem and silk growth at low water potentials in maize. Planta. Berlin, 164:540543.

WILSON, J.R., 1976. Variation on leaf characteristics with level of insertion on a grass tiller. I. Development rate, chemical composition and dry matter digestibility. Australian Journal of Agricultural Research. East Melbourne, 27:343354 .

WILSON, J.R. e L. H: MANNETJE, 1978. Senescence, digestibility and carbohydrate content of buffel grass and greeen panic leaves in swards. Australian Journal of Agriculture Research, East Melbourne, 29:503-516.

WILSON, J.R., 1981. The effects of water stress on herbage quality. In: Proceedings of the International Grassland Congress. 14 - Lexington, Ky, USA. p.470-472. 
WILSON, J.R.; M.M. LUDLOW; M.J. FISHER E E.D. SCHULZE, 1980. Adaptation to water stress of the leaf.water relations of four tropical forage species. Australian Journal of Plant Physiology. East Melbourne, 7:207-220.

WILSON, J.R., 1982. Environmental and nutritional factors affecting herbage quality. In: HACKER, J.B.; Ed. Nutritional Limits to Animal production from Pastures. St. Lucia, p. $111-131$.

WILSON, J.R., 1983. Effects of water stress on in vitro dry matter digestibility and ohemical composition of herbage of tropical pasture species. Australian Journal of Agriculture Research. East Melbourne, 34:377-390.

WITHERS, N.J. e B.J. FORDE, 1979. Effects of water stress on Lupinus albus. 111 . Response of seed yield and vegetative growth to water stress imposed during two or three growth stages. New Zealand Journal of Agriculture Research. Wellington, $22: 463-474$.

ZAGATTO, E.A.G.; P.O. JACINTHO; B.F. KRUG; H. BERGAMIN FILHO:

L.C.R. PESSENDA; J. MORTATTI e M.F. GINE, 1981. Manual de anālises de plantas e āguas empregando sistemas de injeção de fluxo. Piracicaba, Centro de Energia Nuclear na Agricultura. $45 p$. 
APENDICE 
Tabela 10-Anālise de variância para taxa de expansao foliar e taxa de emergència foliar

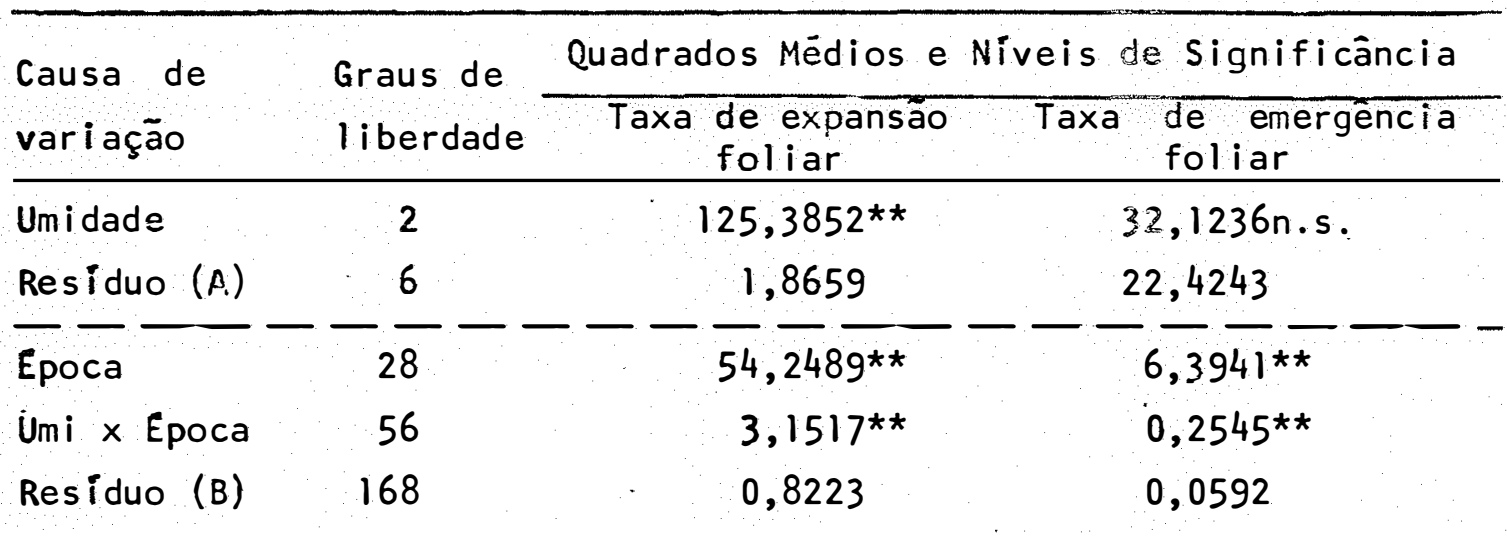

(Ui)

Linear

Quadrātica

cúbica

Quārtica

Desvios
(28)

1

1

1

1

(24)

$\begin{array}{cc}476,8794^{* *} & 106,4080^{* *} \\ 0,2467 \text { n.s. } & 2,5233^{* *} \\ 41,9593^{* *} & 0,0022 \text { n.s. } \\ 1,6529 \text { n.s. } & 0,1058 \text { n.s. } \\ 1,7140 * * & 0,0568 \text { n.s. }\end{array}$

(U2) (28)

Linear

1

Quadrātica

$239,6125^{\star *}$

$37,7537^{\star \star}$

cúbica

1

Quártica

1

$4,8314 * *$

$1,1959 * \star$

Desvios

1

(24)

1,4025 n.s.

$0,3678 * *$

$10,2198 * *$

0,0153 n.s.

$1,6986 * \star$

0,03043 n.s.

(U3) (28)

$\begin{array}{ll}\text { Linear } & 1 \\ \text { Quadrätica } & 1 \\ \text { Cúbica } & 1 \\ \text { Quártica } & 1 \\ \text { Desvios } & (24\end{array}$

$\begin{array}{lrr}28) & 737,8714^{\star \star} & 38,1484^{* \star} \\ 1 & 7,7775^{\star *} & 1,6597^{\star \star} \\ 1 & 30,5994^{\star *} & 1,0322^{\star \star} \\ 1 & 2,5568^{*} & 0,7792^{\star \star} \\ 24) & 2,4147^{\star *} & 0,0501 \text { n.s. }\end{array}$

Coeficiente de variação (\%): (A) 4,67 (extensão); 8,49 (emergência) (B) 16,70 (extensão); 2,35 (emergência) 
Tabela 11 - Anālise de variância para peso seco da parte aerea, matéria orgânica da raíz e, relação raiz:parté aẹerea

\begin{tabular}{|c|c|c|c|c|}
\hline \multirow{2}{*}{$\begin{array}{l}\text { Causa de } \\
\text { variação }\end{array}$} & \multirow{2}{*}{$\begin{array}{l}\text { Graus de } \\
\text { liberdade }\end{array}$} & \multicolumn{3}{|c|}{ Quadrados Médios e Niveis de Significância } \\
\hline & & $\begin{array}{l}\text { Peso seco da } \\
\text { parte aérea }\end{array}$ & $\begin{array}{l}\text { Matéria org. } \\
\text { da raiz }\end{array}$ & $\begin{array}{r}\text { Retaçáo raiz: } \\
\text { parte aérea }\end{array}$ \\
\hline Umidade & 2 & $1746,1944 * \star$ & $89,6253 * \star$ & $0,0002 n . s$ \\
\hline Epoca & 3 & $1687,6574 * \star$ & $155,5389 * *$ & $0,0133 * \star$ \\
\hline Umi $\times$ Epo & 6 & $90,6018 * *$ & $9,6753 * \star$ & $0,001 \mathrm{ln} . \mathrm{s}$. \\
\hline Residuo & 24 & 15,6389 & 2,5675 & 0,0007 \\
\hline (U1) & (3) & & & \\
\hline Linear & 1 & $3330,15^{\star \star}$ & $340,8167 * \star$ & $0,0202 * *$ \\
\hline Quadrātica & 1 & $4,0833 n .5$ & $0,6533 n . s$ & $0,0016 \mathrm{n} . \mathrm{s}$. \\
\hline Desvios & 1 & 43,35 n.s. & 0,2667 n.s. & 0,0007 n.s. \\
\hline (U2) & (3) & & & \\
\hline Linear & 1 & $1363,2667 \star \star$ & $96,5201 * *$ & $0,0058 * \star$ \\
\hline Quadrātica & 1 & 8,3333 n.s. & $0,3675 \mathrm{n} . \mathrm{s}$. & $0,00 \ln . \mathrm{s}$ \\
\hline Desvios & 1 & 1,0667 n.s. & 2,2815 n.s. & 0,0007 n.s. \\
\hline (U3) & (3) & & & \\
\hline Linear & 1 & $763,2667^{\star \star}$ & $83,3082^{\star \star}$ & $0,0115^{\star \star}$ \\
\hline Quadrātica & 1 & 48,0 n.s. & 0,0208 n.s. & $0,0007 \mathrm{n} . \mathrm{s}$. \\
\hline Desvios & 1 & 45,0667 n.s. & $0,4335 \mathrm{n} . \mathrm{s}$. & 0,0002 n.s. \\
\hline
\end{tabular}

Coeficiente de variação (\%): 10,18 (peso seco da parte aérea);

12,55 (matēria orgânica da raiz); 13,57 (relação raiz:parte aérea) 
Tabela 12 - Anālise de variância para número de folhas por planta, nú mero de follhas por perfilho e nümero de perfilhos por planta

\begin{tabular}{|c|c|c|c|c|}
\hline Causa da & Graus de & Quadrados Médio & s e Niveis de $\mathrm{S}$ & ignificância \\
\hline variação & liberdade & $\begin{array}{l}\text { No de folhas/ } \\
\text { planta }\end{array}$ & $\begin{array}{l}\text { No de folhas/ } \\
\text { perfil ho }\end{array}$ & $\begin{array}{l}\text { No de perfilhos } \\
\text { planta }\end{array}$ \\
\hline Umidade & 2 & $521,8667 * \star$ & $0,9722 * \star$ & $16,2889 * *$ \\
\hline Epoca & 4 & $417,4111 * *$ & $2,7878^{\star \star}$ & $6,1889 * \star$ \\
\hline Umi $\times$ Epo & 8 & $53,3944 * \star$ & $0,2203 * \star$ & 0,7056n.s. \\
\hline Resíduo & 30 & 12,9556 & 0,0696 & 1,3778 \\
\hline (UI) & (4) & & & \\
\hline Linear & 1 & $974,7^{* \star}$ & $3,675^{\star *}$ & $12,0333^{\star *}$ \\
\hline Quadrātica & 1 & $262,5^{\star \star}$ & $1,3393 * *$ & 2,8809 n.s. \\
\hline Cúbica & 1 & 36,3 n.s. & 0,0333 n.s. & 4,8 n.s. \\
\hline Desvios & 1 & 39,4333 n.s. & $0,3857^{*}$ & 0,019 n.s. \\
\hline (U2) & (4) & & & \\
\hline Linear & 1 & $264,0333^{\star \star}$ & $2,5813 * \star$ & 0,8333 n.s. \\
\hline Quadrātica & 1 & $61,9286 *$ & $0,8571^{* \star}$ & $0,2143 \mathrm{n} . \mathrm{s}$ \\
\hline Cúbica & 1 & 4,80 n.s. & 0,2253 n.s. & 3,3333 n.s. \\
\hline Desvios & 1 & $0,1714 \mathrm{n} . \mathrm{s}$. & 0,0429 n.s. & $0,019 \mathrm{n.s}$. \\
\hline (u3) & (4) & & & \\
\hline Linear & 1 & 50,7 n.s. & $0,3853 *$ & 0,5333 n.s. \\
\hline Quadrātica & 1 & $360,2143^{\star *}$ & $3,2038 * \star$ & 0,857 ln.s. \\
\hline cúbica & 1 & 24,3 n.s. & $0,108 \mathrm{ln} . \mathrm{s}$. & 4,8 n.s. \\
\hline Desvios & 1 & 17,719 n.s. & 0,0762 n.s. & 0,0762 n.s. \\
\hline
\end{tabular}

Coeficiente de variação $(\%): 10,44$ ( $n$ \% de folhas/planta); 6,74 (n: de folhas/perfilho); 13,41 (n: de perfilhos/planta) 
Tabela 13 - Anālise de variância para \% de fósforo e mg de fósforo na parte aérea

\begin{tabular}{|c|c|c|c|}
\hline \multirow{2}{*}{$\begin{array}{l}\text { Causa da } \\
\text { variação }\end{array}$} & \multirow{2}{*}{$\begin{array}{l}\text { Graus de } \\
\text { liberdade }\end{array}$} & \multicolumn{2}{|c|}{ Quadrados Mëdios e Níveis de Significância } \\
\hline & & $\%$ de $P$ & $\mathrm{mg}$ de $\mathrm{P}$ \\
\hline Umidade & 2 & $0,0005 \mathrm{n} . \mathrm{s}$ & $2498,7778 * \star$ \\
\hline Eöca & 3 & $0,0203 * \star$ & $240,037 * \star$ \\
\hline Umi $\times$ Epo & 6 & $0,0004 n . s$ & 90,5926 n.s. \\
\hline Residuo & 24 & 0,0002 & 50,1944 \\
\hline
\end{tabular}

(Ui)

(3)

Linear 1

Quadrätica $\quad l$

Cúbica $\quad 1$

$0,022 * \star$
$0,0061 * *$
0,0001 n.s.

$317,4^{\star}$

432,0 **

11,2667 n.s.

(U2) (3)

$\begin{array}{lccr}\text { Linear } & 1 & 0,0129 * \star & 459,2667^{\star \star} \\ \text { Quadrätica } & 1 & 0,0008^{*} & 16,3333 \mathrm{n} . \mathrm{s} . \\ \text { Cúbica } & 1 & 0,0001 \mathrm{n} . \mathrm{s} . & 5,40 \mathrm{n.s} .\end{array}$

(U3)

Linear

(3)

Quadrātica

Cúbica
1

1

1

$$
\begin{aligned}
& 0,0194 * t \\
& 0,0016 * t \\
& 0,0003 n . s .
\end{aligned}
$$

5,40 n.s.

16,3333 n.s.

$0,2667 n$. s .

Coeficiente de variação $(\%): 8,54(\%$ de $P) ; 13,11$ (mg de P) 
Tabela 14 - Anālise de variância para \% de potássio e mg de potássio na parte aérea

\begin{tabular}{lccc}
\hline Causa da & Graus de & Quadrados Médios e Niveis de Significância \\
\cline { 3 - 4 } variação & liberdade & \% de K & mg de K \\
\hline Umidade & 2 & $1,2915^{* *}$ & $10002,25 *$ \\
Epoca & 3 & $6,2972 * *$ & $58600,5926 * *$ \\
Umi x Epo & 6 & $0,0451 \mathrm{n} . \mathrm{s}$ & $7180,287 *$ \\
Residuo & 24 & 0,0429 & 2683,3333 \\
\hline
\end{tabular}

\section{(U1)}

Linear

Quadrätica

Desvios

\section{(3)}

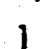

1

1
$4,9766 * *$

$0,5547 * *$

0,0003 n.s.
124579,2667 *

10325,3333 n.s.

385,0667 n.s.
(U2)

$\begin{array}{ll}\text { Linear } & 1 \\ \text { Quadrätica } & 1 \\ \text { Desvios } & 1\end{array}$

\section{(3)}

$\begin{array}{ll}1 & 7,350 * * \\ 1 & 0,0768 \text { n.s. } \\ 1 & 0,0007 \text { n.s. }\end{array}$

18762,0167 **

8164,0833 n.s.

126,15 n.s.
(U3)

Linear

Quadrātica

Desvios
(3)

$\begin{array}{ll}1 & 5,766 * * \\ 1 & 0,3888 * * \\ 1 & 0,0482 \text { n.s. }\end{array}$

55510,4167 * *

630,75 n.s.

$400,4167 n$.s.

Coeficiente de variação (\%): 13,55 (\% de K); 10,06 (mg de K) 
Tabela 15 - Análise de variância para \% de cálcio e mg de cálcio na parte aērea

\begin{tabular}{|c|c|c|c|}
\hline \multirow{2}{*}{$\begin{array}{l}\text { Causa da } \\
\text { variação }\end{array}$} & \multirow{2}{*}{$\begin{array}{l}\text { Graus de } \\
\text { liberdade }\end{array}$} & \multicolumn{2}{|c|}{ Quadrados Mëdios e Níveis de Significância } \\
\hline & & $\%$ de Ca & $\mathrm{mg}$ de $\mathrm{Ca}$ \\
\hline Umidade & 2 & $0,0244 * \star$ & $64353,25 * \star$ \\
\hline Epoca & 3 & $0,09783 * \star$ & $11717,3611 * *$ \\
\hline Umi $\times$ Epo & 6 & $0,0059 *$ & $1224,1389 n . s$ \\
\hline Resíduo & 24 & 0,0024 & 914,5556 \\
\hline (ui) & (3) & $-\quad \cdots$ & \\
\hline Linear & 1 & $0,1540 \star \star$ & $16934,4 \star \star$ \\
\hline Quadrātica & 1 & $0,0005 n . s$ & 1875,0 n.s. \\
\hline Desvios & 1 & 0,0008 n.s. & 299,2667 n.s. \\
\hline
\end{tabular}

(U2)

(3)

$\begin{array}{ll}\text { Linear } & 1 \\ \text { Quadrätica } & 1 \\ \text { Desvios } & 1\end{array}$

$0,0322 \star \star$

$13231,35^{\star \star}$

$0,006 \ln . \mathrm{s}$.

494,0833 n.s.

0,0037 n.s.

36,8167 n.s.

(U3)

$\begin{array}{ll}\text { Linear } & 1 \\ \text { Quadrática } & 1 \\ \text { Desvios } & 1\end{array}$

\section{(3)}

1
0,1127 *
$0,0133 *$
0,006 n.s.

1560,6 n.s.

7905,3333 *

160,0667n.s.

Coeficiente de variação (\%): 9,07 (\% de Ca); 15,05 (mg do Ca) 
Tabela 16 - Anālise de variãncia para \% de magnésio e mg de magnésio na parte aérea

\begin{tabular}{lcccc}
\hline Causa da & Graus de & Quadros Médios e Niveis de Significância \\
\cline { 3 - 4 } variação & liberdade & $\%$ de Mg & $\mathrm{mg} \mathrm{de} \mathrm{Mg}$ \\
\hline Umidade & 2 & $0,0119^{\star \star}$ & $26370,25^{\star \star}$ \\
Epoca & 3 & $0,0092^{\star \star}$ & $16423,6574^{\star \star}$ \\
Umi $\times$ Epo & 6 & $0,0081^{\star \star}$ & $541,8796 \mathrm{n} . \mathrm{s}$. \\
Resíduo & 24 & 0,0012 & 337,9167 \\
\end{tabular}

(UI)

Linear
Quadrätica
Desvios

(U2)

(3)

$\begin{array}{ll}\text { Linear } & 1 \\ \text { Quadrātica } & 1 \\ \text { Desvios } & 1\end{array}$

(U3)

Linear 1

Quadrātica

Desvios
(3)

1

1

1

\section{(3)}
$18235,2667 * \star$
705,3333 n.s.
8,0667 n.s.
0,0350 *
0,0001 n.s.
$0,0034 n . s$.

$21888,6 * \star$

243,0 n.s.

273,0667 n.s.

$\begin{array}{ll}0,0071^{\star} & 21888,6 * \star \\ 0,0102^{\star *} & 243,0 \text { n.s. } \\ 0,0004 \text { n.s. } & 273,0667 \text { n.s. }\end{array}$

$\begin{array}{lll}1 & 0,0043 \mathrm{n} . \mathrm{s} . & 7638,8167^{\star \star} \\ 1 & 0,0091^{*} & 3502,0833^{\star \star} \\ 1 & 0,0066^{*} & 28,0167 \mathrm{n} . \mathrm{s}\end{array}$

Coeficiente de variação $(\%): 8,90(\%$ de $\mathrm{Mg}) ; 12,25(\mathrm{mg}$ de $\mathrm{Mg})$ 
Tabela 17. - Anālise de variância para \% de enxôfre e mg de enxôfre na parte aērea

\begin{tabular}{lccc}
\hline Causa da & Graus de & Quadrados Médios e Niveis de Significância \\
\cline { 3 - 4 } variação & liberdade & $\%$ de S & mg de S \\
\hline Umidade & 2 & 0,0009 n.s. & $5353,6944 * *$ \\
Epoca & 3 & $0,0599^{* *}$ & $82,1852 \mathrm{n} . \mathrm{s}$. \\
Umi x Epo & 6 & $0,0019^{*}$ & $156,1018 \mathrm{n} . \mathrm{s}$. \\
Resíduo & 24 & 0,0005 & 164,4444 \\
\end{tabular}

(UI)

$\begin{array}{llll}\text { Linear } & 1 & 0,0889 * * & 54,15 \mathrm{n} . \mathrm{s} . \\ \text { Quadrätica } & 1 & 0,0091^{* *} & 90,75 \mathrm{n} . \mathrm{s} . \\ \text { Desvios } & 1 & 0,0001 \text { n.s. } & 6,0167 \text { n.s. }\end{array}$

(U2)

(3)

$\begin{array}{lccc}\text { Linear } & 1 & 0,0522^{* \star} & 421,35 \mathrm{n} . \mathrm{s} . \\ \text { Quadrätica } & 1 & 0,0007 \mathrm{n} . \mathrm{s} & 6,75 \mathrm{n} . \mathrm{s} . \\ \text { Desviós } & 1 & 0,0002 \mathrm{n} . \mathrm{s} & 8,8167 \mathrm{n} . \mathrm{s} .\end{array}$

(U3)

(3)

Linear 1

$0,0375^{\star *} \quad 77,0667$ n.s.

Quadrätica 1

$0,000 \mathrm{ln} . \mathrm{s}$.

507,0 n.s.

Desvios

1

$0,0027 *$

$0,0685 n$.s.

Coeficiente de variação (\%): 9,39 (\% de $\mathrm{s}) ; 14,79$ (mg de $\mathrm{s})$ 
Tabela 18 - Anālise de variância para eficiência do uso de fósforo e eficiência do uso de potássio

\begin{tabular}{|c|c|c|c|}
\hline \multirow{2}{*}{$\begin{array}{l}\text { Causa da } \\
\text { variação }\end{array}$} & \multirow{2}{*}{$\begin{array}{l}\text { Graus de } \\
\text { liberdade }\end{array}$} & \multicolumn{2}{|c|}{ Quadrados Médios e Níveis de Significância } \\
\hline & & Efic.do uso de P & Efic. do uso de $K$ \\
\hline Umidade & 2 & 21558,3333 n.s. & $6145,75^{\star *}$ \\
\hline Epoca & 3 & $343699,2963 * *$ & $14298,0 * \star$ \\
\hline Umi $\times$ Epo & 6 & 11263,7407 n.s. & $781,75^{\star *}$ \\
\hline Resíduo & 24 & 5847,5 & 131,5 \\
\hline (U1) & (3) & & \\
\hline Linear & 1 & $395606,4 * \star$ & $28210,167 * \star$ \\
\hline Quadrātica & 1 & $92225,3333 * *$ & 18,75 n.s. \\
\hline Desvios & 1 & $37800,6 *$ & $620,8167^{\star}$ \\
\hline (U2) & (3) & & \\
\hline Linear & 1 & $250131,2667 * \star$ & $10166,0167 * *$ \\
\hline Quadrätica & 1 & 2883,0 n.s. & $630,75^{\star}$ \\
\hline Desvios & 1 & 194,4 n.s. & 12,15 n.s. \\
\hline (U3) & (3) & & \\
\hline Linear & 1 & $298779,2667^{\star \star}$ & $7661,4 * \star$ \\
\hline Quadrätica & 1 & 7500,0 n.s. & $8,3333 \mathrm{n} . \mathrm{s}$. \\
\hline Desvios & 1 & 13560,0667 n.s. & 256,2667 n.s. \\
\hline
\end{tabular}

